\title{
Craford, Forrest Named 1999 MRS Medalists
}

The Materials Research Society (MRS) has selected two scientists to receive the 1999 MRS Medal awards, which recognize a specific outstanding recent discovery or advancement that is expected to have a major impact on the progress of any materials-related field. M. George Craford of Hewlett Packard and Stephen Forrest of Princeton University will receive their medals at the 1999 MRS Fall Meeting during the Awards Ceremony on Wednesday, December 1, at 6:00 p.m. in Salon E of the Boston Marriott Hotel.

M. George Craford is named MRS Medalist "for pioneering contributions and leadership in the development of visiblespectrum light-emitting diode materials and devices." During the past 30 years of research, Craford, with his research groups, introduced the yellow light-emitting diode (LED) (GaAsP:N) and the transparentsubstrate high brightness red-orange-yellow In(AlGa)P LEDs and lamps which exceed in performance the standard incandescent lamp.

Craford's numerous seminal contributions to LED research is leading the transition from conventional lighting sources to solid-state emitters. The commercial quality of LEDs that Craford has developed results from several risks and challenges that he had undertaken. Craford's research group introduced commercial yellow and orange LEDs based on research on the effects of $\mathrm{N}$ isoelectronic doping in GaAsP ternary alloys grown by hydride vaporphase epitaxy (VPE). This work advanced understanding of the fundamental role of isoelectronic impurities in compound semiconductors.

Subsequently, Craford used the previously unproven technique of metalorganic chemical vapor deposition (MOCVD) crystal growth to produce high-efficiency LEDs from Al-containing III-V materials. $\mathrm{He}$ and his co-workers demonstrated the first high-brightness yellow AlGaInP LEDs that exhibited higher $1 \mathrm{~m} / \mathrm{W}$ than unfiltered incandescent lamps. He and his group developed the wide bandgap process for the deposition of thick latticemismatched GaP cap layers on MOCVDgrown InAlGaP heterostructures grown on GaAs substrates.

More recently, Craford and his research team have implemented new techniques of compound semiconductor wafer bonding in order to produce orange-red spectrum devices whose efficiency $(\mathrm{lm} / \mathrm{W})$ exceed unfiltered incandescent sources along with several other conventional lighting sources such as halogen lamps.

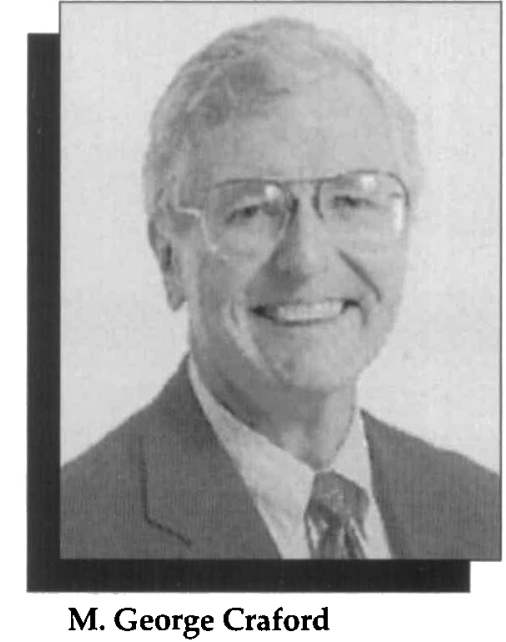

This technique involves development of a full, 2.0 in. diameter wafer bonding and epitaxial lift-off process that permits researchers to completely remove the GaAs absorbing substrate from an InAIGaP heterojunction LED wafer and to bond it to a transparent $\mathrm{GaP}$ wafer.

Since 1982, Craford has been the research and development manager of the HP Optoelectronics Division. Prior to joining $\mathrm{HP}$ in 1979, Craford worked for 12 years at Monsanto, advancing to technology director in the Monsanto Electronics Division in 1974. He received his MS (1963) and PhD (1967) degrees in physics at the University of Illinois. Among his several honors and memberships are the National Academy of Engineering, Institute of Electrical and Electronics Engineers (IEEE) Fellowship, and IEEE Morris N. Liebmann Memorial Award. He has over 50 publications, including a comprehensive reference text, High Brightness LightEmitting Diodes (Academic Press, San Diego, 1997), and several patents.

Craford will deliver his Medalist talk in Symposium $X$ on Wednesday, December 1 , 12:45 p.m., in Room 208 of the Hynes Convention Center, on "Visible Light Emitting Diodes (LEDs): Past, Present, and Very Bright Future."

Stephen Forrest is named MRS Medalist "for pioneering contributions to the growth and optoelectronic applications of organic semiconductor thin films." He has set and continues to set the standard of growth and characterization in the emerging area of electrical properties and device structures based on ultrathin organic films.

With his research team, Forrest's studies led to the discovery and unraveling of many growth modes of van der Waals (vdW) bonded organic thin films onto a

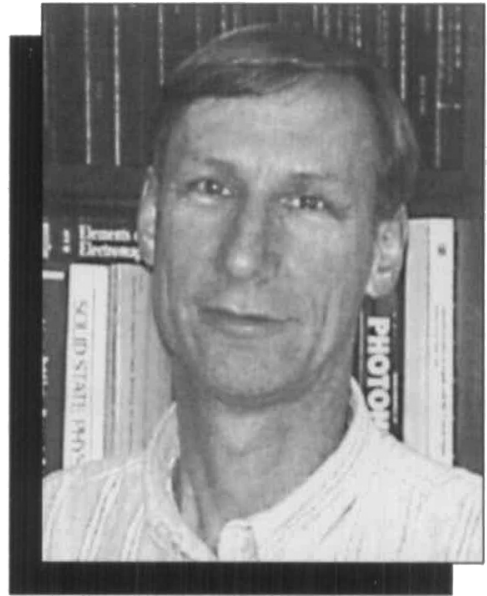

Stephen Forrest

wide range of substrates. This has led to the development of models for understanding and predicting the structure these growth modes. This work also led to the first demonstration of the growth of organic multiple quantum well (MQW) structures, which exhibited quantum effects on the excitonic spectrum in closepacked vdW solids, then to the development of a quantitative model for quantum confinement of charge-transfer excitons in organic MQWs. Forrest's work has furthermore led to the development of novel organic/inorganic integrated devices for which he engineered a process where a molecular-beam-epitaxially grown III-V semiconductor is combined with an organicmolecular-beam-deposition-grown organic thin film in a single, ultrahigh vacuum environment.

Forrest's work has led to fundamental and applied advances in organic electroluminescent devices (OLEDs), and most recently in a 12-layer, 3-color stacked OLED (SOLED) which combines layers of crystalline and amorphous organics, conducting oxides and metals in a single stacked structure. Forrest and his colleagues were the first to identify fundamental current limiting mechanisms in molecular OLEDs, to demonstrate a fully transparent OLED, and to fabricate efficient OLEDs with the same metal oxide (indium-tin-oxide) used as both the anode and cathode.

Finally, Forrest and co-workers demonstrated lasing in semiconducting organic molecular thin films, opening the possibility for the eventual realization of all organic electrically pumped lasers.

Forrest's work has opened research in the areas of organic epitaxy and utilization of quantum effects in vdW solids and in 
polymers; in fundamental physics and applications of these heterojunctions; and toward the design and fabrication of electrically pumped organic lasers.

After receiving his MS (1974) and $\mathrm{PhD}$ (1979) degrees in physics from the University of Michigan-Ann Arbor, Forrest worked for Bell Laboratories, the University of Southern California, and in 1992 joined Princeton University. He has over 230 publications, several patents, and has received numerous honors and is an IEEE Fellow.

Forrest will deliver his talk in Symposium X on Monday, November 29, 12:45 p.m., in Room 208 of the Hynes Convention Center, on "Science and Technology at the Nanometer Scale Using VacuumDeposited Organic Thin Film." MIRS

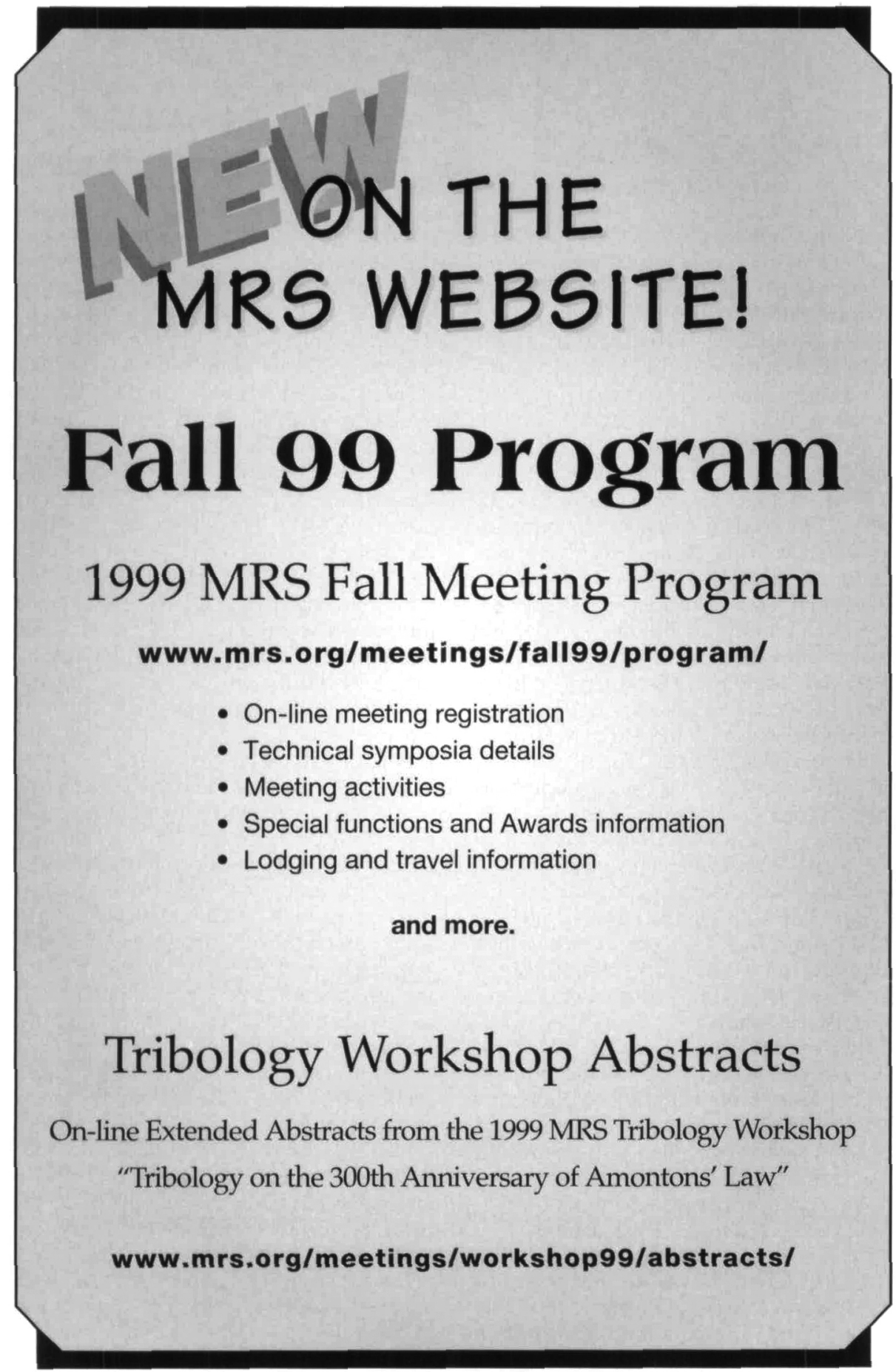

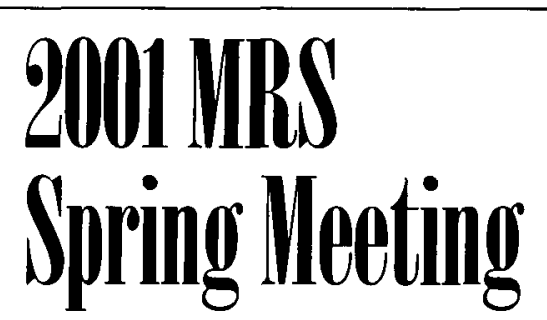

April 16-20 San Francisco, CA

Meeting (hiirs:

\section{Nicholas Cowern WAG 01}

Philips Research Laboratories

NL-5656 AA Eindhoven

The Netherlands

Phone 31-40-2742858

Fax 31-40-2743390

cowern@natlab.research.

philips.com

\section{Tomas Diaz de la Rubia}

Chemistry and Materials

Directorate L-353

Lawrence Livermore National

Laboratory

7000 East Avenue

Livermore, CA 94550

Phone 925-422-6714

Fax 925-422-7300

delarubia@|lnl.gov

\section{Chad A. Mirkin}

Department of Chemistry

Northwestern University

2145 Sheridan Road

Evanston, IL 60208

Phone 847-491-2907

Fax 847-467-5123

camirkin@chem.nwu.edu

\section{Cynthia Volkert}

Max-Planck-Institute

Seestrasse 92

Stuttgart 70174

Germany

Phone 49-711-2095123

Fax 49-711-2095120

thia@finix.mpi-stuttgart.mpg.de 


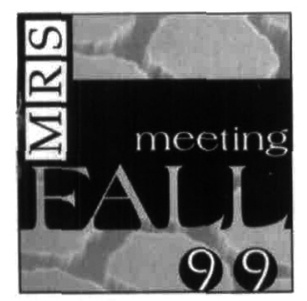

NOVEMBER 29. DECEMBER 3

BOSTON

MASSACHUSETTS

HYNES CONVENTION

CENTER

and

BOSTON MARRIOTT

COPLEY PLACE

Special premeeting

prices effective until

December 17, 1999

(After that, pay the higher price on the right.)

\section{These books are scheduled for publication by spring or early summer 2000.}

\section{MTRS}

\section{Materials}

Research Society

506 Keystone Drive Warrendale, PA 15086-7573 U.S.A. Tel: 724-779-3003

Fax: 724-779-8313

E-mail: info@mrs.org wWw.mrs.org/publications/books/
A: Multiscale Phenomena in MaterialsExperiments and Modeling

Editors: D.H. Lassila, I.M. Robertson, R. Phillips, B. Devincre

$\begin{array}{ccl}\text { ISBN: } 1-55899-486-6 & \text { Code: } 578-B \\ \$ 70.00 & \$ 81.00 & \text { MRS Member } \\ \$ 81.00 & \$ 93.00 & \text { U.S. List } \\ \$ 93.00 & \$ 106.00 & \text { Non-U.S. }\end{array}$

B: The Optical Properties of Materials Editors: J.R. Chelikowsky, S.G. Louie, G. Martinez,

E.L. Shirley
ISBN: $1-55899-487-4$

$\begin{array}{lll}\text { N: } 1-55899-487-4 & \text { Code: } & 579-B \\ \$ 65.00 & \$ 75.00 & \text { MRS Member } \\ \$ 75.00 & \$ 86.00 & \text { U.S. List } \\ \$ 86.00 & \$ 99.00 & \text { Non-U.S. }\end{array}$

E: Nucleation and Growth Processes in Materials Editors: A. Gonis, P.E.A. Turchi, A.J. Ardell

ISBN: $1-55899-488-2 \quad$ Code: $580-\mathrm{B}$

$\begin{array}{lll}\$ 70.00 & \$ 81.00 & \text { MRS Member } \\ \$ 81.00 & \$ 93.00 & \text { U.S. List }\end{array}$

$\begin{array}{lll}\$ 81.00 & \$ 93.00 & \text { U.S. List } \\ \$ 93.00 & \$ 106.00 & \text { Non-U.S }\end{array}$

F: Nanophase and Nanocomposite Materials III Editors: S. Komarneni, J.C. Parker, H. Hahn

ISBN: 1-5899-489-0 Code: 581-B $\begin{array}{lll}\$ 75.00 & \$ 86.00 & \text { MRS Member } \\ \$ 86.00 & \$ 99.00 & \text { US. List }\end{array}$ $\begin{array}{lll}\$ 86.00 & \$ 99.00 & \text { U.S. List } \\ \$ 99.00 & \$ 114.00 & \text { Non-U.S. }\end{array}$

: Molecular Electronics

Editors: S.T. Pantelides, M.A. Reed, J. Murday,

A. Aviram

$\begin{array}{ccl}\text { ASBN: } 1-55899-490-4 & \text { Code: } 582-B \\ \$ 68.00 & \$ 78.00 & \text { MRS Member } \\ \$ 78.00 & \$ 90.00 & \text { U.S. List } \\ \$ 90.00 & \$ 103.00 & \text { Non-U.S. }\end{array}$

I: Self-Organized Processes in Semiconductor Alloys

Editors: A. Mascarenhas, B. Joyce, T. Suzuki, D. Follstaedt

$\begin{array}{ccl}\text { ISBN: } 1-55899-491-2 & & \text { Code: } 583-B \\ \$ 70.00 & \$ 81.00 & \text { MRS Member } \\ \$ 81.00 & \$ 93.00 & \text { U.S. List } \\ \$ 93.00 & \$ 106.00 & \text { Non-U.S. }\end{array}$

$\mathrm{J} / \mathrm{N}$ : Materiais issues and Modeling for Device Nanofabrication

Editors: L. Merhari, L.T. Wille, K. Gonsalves, M.F. Gyure, S. Matsui, L.J. Whitman

ISBN: 1-55899-492-0

$\begin{array}{lll}\$ 70.00 & \$ 81.00 & \text { Code: } 584-B \\ \$ 81.00 & \$ 93.00 & \text { MRS Member } \\ \$ 93.00 & \$ 106.00 & \text { U.S. List }\end{array}$

$\$ 93.00 \$ 106.00$ Non-U.S.

L: Fundamental Mechanisms of Low-EnergyBeam-Modified Surface Growth and Processing

Editors: S. Moss, E.H. Chason, B.H. Cooper,

T. Diaz de la Rubia, J.M.E. Harper, R. Murti

SBN: 1-55899-493-9 Code: 585-B $\begin{array}{lll}\$ 65.00 & \$ 75.00 & \text { MRS Member }\end{array}$ $\begin{array}{lll}\$ 75.00 & \$ 86.00 & \text { U.S. List } \\ \$ 86.00 & \$ 99.00 & \text { Non-U.S.Non-U.S. }\end{array}$

M: Interfacial Engineering for Optimized Properties II

Editors: C.B. Carter, E.L. Hall, C.L. Briant, S. Nutt

ISBN: 1-55899-494-7 Tal, Code: 586-B $\begin{array}{lll}\$ 68.00 & \$ 78.00 & \text { Code: } 586-B \\ & \text { MRS Member }\end{array}$ $\begin{array}{lll}\$ 78.00 & \$ 90.00 & \text { U.S. List } \\ \$ 90.00 & \$ 103.00 & \text { Non-U.S. }\end{array}$

0: Substrate Engineering-Paving the Way to Epitaxy

Editors: D.P. Norton, D.G. Schlom, N. Newman,

D.H. Matthiesen

SBN: $1-55899-495-5 \quad$ Code: $587-B$ $\$ 68.00 \quad \$ 78.00 \quad$ MRS Member $\begin{array}{lll}\$ 78.00 & \$ 90.00 & \text { U.S. List } \\ \$ 90.00 & \$ 103.00 & \text { Non-U.S. }\end{array}$

P: Optical Microstructural Characterization of Semiconductors

Editors: J. Piqueras, T. Sekiguchi, M.S. Unlu,

N.M. Kalkhoran

ISBN: $1-55899-496-3 \quad$ Code: $588-B$

$\$ 68.00 \quad \$ 78.00 \quad$ MRS Member

$\$ 78.00 \quad \$ 90.00 \quad$ U.S. List
0: Advances in Materials Problem Solving with the Electron Microscope

Editors: J. Bentley, U. Dahmen, C. Allen, I. Petrov

ISBN: 1-55899-497-1 Code: 589-B

$\$ 70.00 \$ 81.00 \quad$ MRS Member

$\$ 81.00 \quad \$ 93.00 \quad$ U.S. List

R: Applications of Synchrotron Radiation Techniques to Materials Science V

Editors: S.R. Stock, D.L. Perry, S.M. Mini

ISBN: 1-55899-498-X Code: 590-B

$\begin{array}{lll}\$ 68.00 & \$ 78.00 & \text { MRS Member } \\ \$ 78.00 & \$ 90.00 & \text { U.S. List }\end{array}$

$\begin{array}{lll}\$ 78.00 & \$ 90.00 & \text { U.S. List } \\ \$ 90.00 & \$ 103.00 & \text { Non-U.S. }\end{array}$

S: Nondestructive Methods for Materials Characterization

Editors: T. Matikas, N. Meyendorf, G. Baaklini,

R. Gilmore

ISBN: 1-55899-499-8

$\begin{array}{lll}\$ 68.00 & \$ 78.00 & \text { Mode: } 591-B \\ \$ 78.00 & \$ 90.00 & \text { MRS Member } \\ \$ 90.00 & \$ 103.00 & \text { Non-U.S. }\end{array}$

$\$ 90.00 \quad \$ 103.00 \quad$ Non-U.S.

T: Structure and Electronic Properties of Ultrathin Dielectric Films on Silicon and Related Structures

Editors: H.J. von Bardeleben, D.A. Buchanan,

A.H. Edwards, T. Hattori

ISBN: 1-55899-500-5

$\begin{array}{lll}\$ 65.00 & \$ 75.00 & \text { Code: } 592-B \\ \$ 75.00 & \$ 86.00 & \text { MRS Member } \\ \$ 86.00 & \$ 99.00 & \text { U.S. List } \\ & \text { Non-U.S. }\end{array}$

U: Amorphous and Nanostructured Carbon Editors: J. Robertson, J.P. Sullivan, 0. Zhou

T.B. Allen, B.F. Coll

ISBN: 1-55899-501-3

$\begin{array}{lll}\$ 72.00 & \$ 83.00 & \text { MRS Member } \\ \$ 83.00 & \$ 95.00 & \text { U.S. List } \\ \$ 95.00 & \$ 110.00 & \text { Non-U.S. }\end{array}$

V: Thin Films-Stresses and Mechanical Properties VIII

Editors: R. Vinci, O. Kraft, N. Moody, P. Besser, E. Shaffer II

ISBN: 1-55899-502-1

$\begin{array}{ccl}\text { N : } 1-55899-502-1 & \text { Code: } 594-B \\ \$ 70.00 & \$ 81.00 & \text { MRS Membe } \\ \$ 81.00 & \$ 93.00 & \text { U.S. List } \\ \$ 93.00 & \$ 106.00 & \text { Non-U.S. }\end{array}$

W: GaN and Related Alloys-1999

Editors: R. Feenstra, T. Myers, M.S. Shur,

H. Amano

ISBN: 1-55899-503-X

$\begin{array}{lll}\text { N: } 1-55899-503-X & \text { Code: } 595-B \\ \$ 75.00 & \$ 86.00 & \text { MRS Member } \\ \$ 86.00 & \$ 99.00 & \text { U.S. List } \\ \$ 99.00 & \$ 114.00 & \text { Non-U.S. }\end{array}$

$\$ 99.00$

Y: Ferroelectric Thin Films VIII
Editors: R.W. Schwart, S.R. Summerfelt,

P.C. Mcintyre, Y. Miyasaka, D. Wouters

ISBN: $1-55899-504-8 \quad$ Code: 596-B

$\$ 70.00$ \$ 81.00 MRS Member

$\begin{array}{lll}\$ 81.00 & \$ 93.00 & \text { U.S. List } \\ \$ 93.00 & \$ 106.00 & \text { Non-U.S. }\end{array}$

Z/PP: Thin Films for Optical Waveguide Devices and Materials for Optical Limiting

Editors: K. Nashimoto, B.W. Wessels,

J. Shmulovich, A.K-Y. Jen, K. Lewis, R. Pachter,

R. Sutherland, J. Perry

ISBN: 1-55899-505-6

$\$ 70.00 \$ 81.00 \quad$ MRS Member

$\begin{array}{lll}\$ 81.00 & \$ 93.00 & \text { U.S. List } \\ \$ 93.00 & \$ 106.00 & \text { Non-U.S. }\end{array}$

BB: Electrical, Optical, and Magnetic Properties of Organic Solid-State Materials V

Editors: S.P. Ermer, J.R. Reynolds, J.W. Perry,

A.K-Y. Jen, Z. Bao

ISBN: 1-55899-506-4

$\begin{array}{lll}\$ 73.00 & \$ 84.00 & \text { Code: } 598-B \\ \$ 84.00 & \$ 97.00 & \text { MRS Member } \\ & \text { U.S. List }\end{array}$

$\$ 84.00 \quad \$ 97.00 \quad$ U.S. List
DD: Mineralization in Natural and Synthetic Biomaterials

Editors: P. Li, P. Calvert, R.J. Levy, T. Kokubo,

C.R. Scheid

ISBN: 1-55899-507-2 Code: 599-B

$\begin{array}{lll}\$ 65.00 & \$ 75.00^{\circ} & \text { MRS Member } \\ \$ 75.00 & \$ 86.00 & \text { U.S. List }\end{array}$

$\begin{array}{lll}\$ 75.00 & \$ 86.00 & \text { U.S. List } \\ \$ 86.00 & \$ 99.00 & \text { Non-U.S }\end{array}$

FF: Electroactive Polymers

Editors: Q.M. Zhang, T. Furukawa, Y. Bar-Cohen,

J. Scheinbeim

ISBN: 1-55899-508-0

$\begin{array}{lll}\$ 68.00 & \$ 78.00 & \text { MRS Member } \\ \$ 78.00 & \$ 90.00 & \text { U.S. List } \\ \$ 90.00 & \$ 103.00 & \text { Non-U.S. }\end{array}$

HH: Superplasticity - Current Status and Future Potential

Editors: P.B. Berbon, M.Z. Berbon, T. Sakuma, T.G. Langdon

$\begin{array}{lll}\$ 68.00 & \$ 78.00 & \text { MRS Membe } \\ \$ 78.00 & \$ 90.00 & \text { U.S. List } \\ \$ 90.00 & \$ 103.00 & \text { Non-U.S. }\end{array}$

JJ: Magnetoresistive Oxides and Related Materials

Editors: M. Rzchowski, M. Kawasaki, A.J. Millis, M. Rajeswari, S.von Molnár

ISBN: 1-55899-510-2

$\begin{array}{lll}\$ 70.00 & \$ 81.00 & \text { MRS Member } \\ \$ 81.00 & \$ 93.00 & \text { U.S. List }\end{array}$

$\begin{array}{lll}\$ 81.00 & \$ 93.00 & \text { U.S. List } \\ \$ 93.00 & \$ 106.00 & \text { Non-U.S. }\end{array}$

KK: Materials Issues for Tunable RF and Microwave Devices

Editors: Q. Jia, F.A. Miranda, D.E. Oates, X. X

ISBN: 1-55899-511-0 Code: 603-B $\$ 68.00 \$ 78.00 \quad$ MRS Member $\$ 78.00 \quad \$ 90.00 \quad$ U.S. List $\$ 90.00 \quad \$ 103.00 \quad$ Non-U.S.

LL: Materiais for Smart Systems III

Editors: M. Wun-Fogle, K. Uchino, Y. Ito, R. Gotthardt

ISBN: $1-55899-512-9 \quad$ Code: 604-B $\$ 68.00 \$ 78.00 \quad$ MRS Member $\$ 78.00 \quad \$ 90.00 \quad$ U.S. List $\$ 90.00 \$ 103.00 \quad$ Non-U.S.

MM: Materials Science of Microelectromechanical Systems (MEMS) Devices II

Editors: M.P. deBoer, A.H. Heuer, S.J. Jacobs, E. Peeters

ISBN: 1-55899-513-7 Code: 605-B

$\$ 68.00 \$ 78.00 \quad$ MRS Member

$\$ 78.00 \quad \$ 90.00 \quad$ U.S. List

$\$ 90.00 \$ \$ 103.00 \quad$ Non-U.S.

NN: Chemical Processing of Dielectrics. Insulators and Electronic Ceramics

Editors: A.C. Jones, J. Veteran, S. Kaushal, D. Mullin,

R. Cooper

ISBN: 1-55899-514-5

$\begin{array}{lll}\text { N : } 1-55899-514-5 & \text { Code: } 606-B \\ \$ 68.00 & \$ 78.00 & \text { MRS Member } \\ \$ 78.00 & \$ 90.00 & \text { U.S. List } \\ \$ 90.00 & \$ 103.00 & \text { Non-U.S. }\end{array}$

00: Infrared Applications of Semiconductors III

Editors: B.J.H. Stadler, M.O. Manasreh, I. Ferguson,

Y-H. Zhang

ISBN: 1-55899-515-3

$\begin{array}{lll}\$ 70.00 & \$ 81.00 & \text { MRS Member } \\ \$ 81.00 & \$ 93.00 & \text { U.S. List } \\ \$ 93.00 & \$ 106.00 & \text { Non-U.S. }\end{array}$

QQ: Scientific Basis for Nuclear Waste Management XXIII

Editors: R.W. Smith, D.W. Shoesmith

ISBN: 1-55899-516-1 Code: 608-B

$\$ 72.00 \$ \$ 83.00 \quad$ MRS Member

$\$ 83.00 \quad \$ 95.00 \quad$ U.S. List

$\$ 95.00 \quad \$ 110.00 \quad$ Non-U.S. 
Symposium Session Locator

\begin{tabular}{|c|c|c|c|c|c|c|c|c|}
\hline & \multirow[t]{2}{*}{ SYMPOSIUM } & \multirow[t]{2}{*}{ LOCATION } & \multicolumn{3}{|c|}{ MONDAY, NOVEMBER 29} & \multicolumn{3}{|c|}{ TUESDAY, NOVEMBER 30} \\
\hline & & & a.m. & p.m. & eve.* & a.m. & p.m. & eve.* \\
\hline A: & $\begin{array}{l}\text { Multiscale Phenom. in } \\
\text { Matls.-Expmts. \& Mod. }\end{array}$ & $\underset{(H)}{\operatorname{Room}} 208$ & & & & $\begin{array}{l}\text { A1: Plasticity at Small Length } \\
\text { Scales \& Continuum }\end{array}$ & $\begin{array}{l}\text { A2: Nonlocal Plasticity } \\
\text { Theory \& Disloc. Phenom. }\end{array}$ & A3: Posters \\
\hline B: & $\begin{array}{l}\text { Comp. Approaches to } \\
\text { Predicting the Optical } \\
\text { Properties of Matis. }\end{array}$ & $\begin{array}{c}\text { Room } 209 \\
(\mathbf{H})\end{array}$ & & & & B1 & B2 & \\
\hline C: & $\begin{array}{l}\text { Microstructural Model- } \\
\text { ing for Industrial } \\
\text { Metals Processing }\end{array}$ & $\underset{(H)}{\operatorname{Room}} 209$ & $\begin{array}{l}\text { C1: Casting and Solidification } \\
\text { C2: Deformation \& Texture I }\end{array}$ & $\begin{array}{l}\text { C3: Deformation \& Texture II } \\
\text { C4: Powder \& Special } \\
\text { Processes }\end{array}$ & & $\begin{array}{l}\text { C5: Thermal Processes \& } \\
\text { Phase Transformations } \\
\text { ROOM } 205\end{array}$ & & \\
\hline D: & $\begin{array}{l}\text { New Advances in } \\
\text { Materials Prediction }\end{array}$ & $\begin{array}{c}\text { Room } 207 \\
(H)\end{array}$ & & & & & $\begin{array}{l}\text { D1: Predictions in } \\
\text { Advanced Materials }\end{array}$ & \\
\hline E: & $\begin{array}{l}\text { Nucleation \& Growth } \\
\text { Processes in Materials }\end{array}$ & $\underset{(H)}{R o o m} 210$ & $\begin{array}{l}\text { E1: Phase Transformations I } \\
\text { E2: Phase Transformations II }\end{array}$ & $\begin{array}{l}\text { E3: Phase Transformations III } \\
\text { E4: Phase Transformations IV }\end{array}$ & E5: Posters & $\begin{array}{l}\text { E6: Liquid-Solid Transform. I } \\
\text { E7: Liquid-Solid Transform. II }\end{array}$ & $\begin{array}{l}\text { E8: Liq.-Solid Transform. III } \\
\text { E9: Martensitic Transform. }\end{array}$ & E10: Posters \\
\hline $\mathrm{F}:$ & $\begin{array}{l}\text { Nanophase \& } \\
\text { Nanocomposite } \\
\text { Materials III }\end{array}$ & $\begin{array}{l}\text { Salon F } \\
\text { (M) }\end{array}$ & F1: Nanocomposites & F2: Nanophase Ceramics & & $\begin{array}{l}\text { F3: Sol-Gel \& Organic/lnorganic } \\
\text { Nanocomposites }\end{array}$ & $\begin{array}{l}\text { F4: Nanophase } \\
\text { Semiconductors }\end{array}$ & F5: Posters \\
\hline G: & \begin{tabular}{l|} 
Nonlithographic \\
Approaches to Micro- \& \\
Nanoscale Organization
\end{tabular} & $\underset{(M)}{\text { Salon } E}$ & $\begin{array}{l}\text { G1: Printing, Molding, Transfer. } \\
\text { \& Other Techniques i }\end{array}$ & G2: Nanoparticle Arrays & & $\begin{array}{l}\text { G3: Printing. Molding, Transfer, } \\
\text { \& Other Techniques il }\end{array}$ & $\begin{array}{l}\text { G4: Biomolecular \& } \\
\text { Biomimetic Assembly }\end{array}$ & \\
\hline $\mathrm{H}:$ & Molecular Electronics & $\begin{array}{l}\text { Cape Cod/ } \\
\text { Hyannis } \\
\text { (M) }\end{array}$ & $\begin{array}{l}\mathrm{H} 1 \\
\mathrm{H} 2\end{array}$ & $\begin{array}{l}\mathrm{H}_{3} \\
\mathrm{H}_{4}\end{array}$ & & $\begin{array}{l}\mathrm{H} 5 \\
\mathrm{H} 6\end{array}$ & $\begin{array}{l}\mathrm{H} 7 \\
\mathrm{H} 8\end{array}$ & \\
\hline I: & $\begin{array}{l}\text { Self-Organized Proc. in } \\
\text { Semiconductor Alloys }\end{array}$ & $\begin{array}{l}\text { Wellesley } \\
\text { (M) }\end{array}$ & 11: Quantum Dots I & $\begin{array}{l}\text { 12: Spontaneous Ordering } \\
\text { in Semiconductor Alloys }\end{array}$ & & |3: Quartum Dots II & $\begin{array}{l}\text { 14: Composition Modulation } \\
\text { in Semiconductor Alloys }\end{array}$ & \\
\hline J: & $\begin{array}{l}\text { Adv. Matls. \& Techs. for } \\
\text { Nanolithography } \\
\text { Sunday Tutorial Session* }\end{array}$ & $\begin{array}{l}\text { Boston } \\
\text { College } \\
\text { (M) }\end{array}$ & $\begin{array}{l}\text { J1: Advances in Photo \& X- } \\
\text { Ray Lithographies: Issues for } \\
\text { Molecular Scale Electronics }\end{array}$ & $\begin{array}{l}\text { J2: Advanced Resists } \\
\text { \& Characterization }\end{array}$ & & $\begin{array}{l}\text { J3: Advances in Electron Beam, } \\
\text { lon Beam, \& Soft Lithographies }\end{array}$ & $\begin{array}{l}\text { J4: New Concepts for } \\
\text { Materials Design }\end{array}$ & \\
\hline K: & $\begin{array}{l}\text { Thermal Spray- } \\
\text { Materials Synthesis } \\
\text { by Thermal Spraying }\end{array}$ & $\begin{array}{c}\text { Room } 309 \\
(H)\end{array}$ & $\begin{array}{l}\text { K1: Spray Process Charac- } \\
\text { terization by Modeling \& } \\
\text { Diagnostics }\end{array}$ & $\begin{array}{l}\text { K2: Honorary Sess. for Prof. } \\
\text { Herman-Spray Caating } \\
\text { Formation \& Evaluation }\end{array}$ & K3: Posters & $\begin{array}{l}\text { K4: Synthesis of Powders \& } \\
\text { Nanostructured Materials } \\
\text { ROOM } 308\end{array}$ & $\begin{array}{l}\text { K5: New Proc. for Powder \& } \\
\text { Coating Formation \& Eval. } \\
\text { ROOM } 308\end{array}$ & \\
\hline L: & $\begin{array}{l}\text { Fundamental Mechs. of } \\
\text { Low-Energy-Beam-Mod. } \\
\text { Surf. Growth \& Proc. }\end{array}$ & $\underset{(M)}{\text { Salon } H / I}$ & Tutorial Session"* & $\begin{array}{l}\text { L1: Beam-Induced Surface } \\
\text { Growth \& Modification }\end{array}$ & & $\begin{array}{l}\text { L2/O2/114: Biaxially Textured } \\
\text { Substrates for High- } T_{\mathrm{c}} \\
\text { Coated Conductors } \\
\text { ROOM } \mathbf{2 0 0} \\
\end{array}$ & $\begin{array}{l}\text { L3: Polycrystalline Films- } \\
\text { Microstructure \& Texture }\end{array}$ & L4: Posters \\
\hline M: & $\begin{array}{l}\text { Interfacial Engr. for } \\
\text { Optimized Properties II }\end{array}$ & $\begin{array}{l}\text { Salon } C / D \\
(M)\end{array}$ & & & & & & \\
\hline $\mathrm{N}:$ & $\begin{array}{l}\text { Atomic Scale Meas. \& } \\
\text { Atomistic Models of } \\
\text { Epitax. Growth \& Lith. }\end{array}$ & $\begin{array}{l}\text { Regis } \\
\text { (M) }\end{array}$ & & & & $\begin{array}{l}\text { N1: Morphology, Defects, } \\
\text { \& Device Properties } \\
\text { N2: In-Situ Observations }\end{array}$ & $\begin{array}{l}\text { N3: GaAs Substrates } \\
\text { N4: Atomistic Simulations }\end{array}$ & \\
\hline o: & $\begin{array}{l}\text { Substrate Engi- } \\
\text { neering-Paving } \\
\text { the Way to Epitaxy }\end{array}$ & $\begin{array}{l}\text { Harvard } \\
\text { (M) }\end{array}$ & & $\begin{array}{l}\text { O1/W2: Lateral Epitaxial } \\
\text { Overgrowth } \\
\text { RooM } 302\end{array}$ & & $\begin{array}{l}\text { O2/L2/114: Biax. Textured Subs. } \\
\text { for High- } T_{c} \text { Coated Conductors } \\
\text { ROOM } 200\end{array}$ & $\begin{array}{l}\text { O3: Surtaces for } \\
\text { Oxide Epitaxy }\end{array}$ & \\
\hline P: & $\begin{array}{l}\text { Optical Microstructural } \\
\text { Charac. of Semicond. }\end{array}$ & $\begin{array}{c}\text { Salon } C / D \\
(M)\end{array}$ & $\begin{array}{l}\text { P1: Near-Field Techniques I } \\
\text { P2: Photoelec. \& Reson. Tech. }\end{array}$ & P3: Luminescence I & & $\begin{array}{l}\text { P4: Luminescence \| } \\
\text { P5: Near-Field Techniques ॥ }\end{array}$ & $\begin{array}{l}\text { P6: Raman Spectroscopy } \\
\text { P7: Optical Properties } \\
\end{array}$ & P8: Posters \\
\hline Q: & $\begin{array}{l}\text { Advances in Materials } \\
\text { Problem Solving with } \\
\text { Electron Microscope }\end{array}$ & $\underset{(M)}{\text { Salon } A / B}$ & & & & & $\begin{array}{l}\text { Q1: Magnetic Materials } \\
\text { \& Low-Energy Electron } \\
\text { Microscopy }\end{array}$ & \\
\hline R: & $\begin{array}{l}\text { Applications of Syn- } \\
\text { chrotron Radiation } \\
\text { Tech. to Matls. Science }\end{array}$ & $\begin{array}{l}\text { Suffolk } \\
\text { (M) }\end{array}$ & & R1: General & & $\begin{array}{l}\text { R2: Small-Angle X-Ray } \\
\text { Scattering \& Surfacellnterface } \\
\text { Scattering Techniques I } \\
\text { R3: (Contd) II }\end{array}$ & $\begin{array}{l}\text { A4: Spectromicroscopy } \\
\text { \& Topography I } \\
\text { R5: Spectromicroscopy } \\
\text { \& Topography II }\end{array}$ & \\
\hline s: & $\begin{array}{l}\text { Nondestructive } \\
\text { Methods for Materials } \\
\text { Characterization }\end{array}$ & $\begin{array}{l}\text { P'town/ } \\
\text { Orleans } \\
\text { (M) }\end{array}$ & $\begin{array}{l}\text { S1: Proc. Cntrl. \& Deformation } \\
\text { Behavior via X-Ray Tech. } \\
\text { S2: NDE for Frac. Fat. \& Corr. }\end{array}$ & $\begin{array}{l}\text { S3: Structure-Sensitive } \\
\text { Properties for NDE Charac. } \\
\text { S4: NDE for Concrete \& Steel }\end{array}$ & & $\begin{array}{l}\text { S5: Linear \& Nonlinear } \\
\text { Ultrasonics } \\
\text { S6: Electric \& Optoelec. NDE }\end{array}$ & $\begin{array}{l}\text { S7: NDE for Silicon } \\
\text { Wafers \& Interfaces } \\
\text { S8: Novel Tech. \& Application }\end{array}$ & S9: Posters \\
\hline$T:$ & $\begin{array}{l}\text { Struc. \& Elec. Prop. of } \\
\text { Ultrathin Dielec. Films } \\
\text { on Si \& Rel. Structures }\end{array}$ & $\begin{array}{c}\text { Room } 310 \\
(H)\end{array}$ & 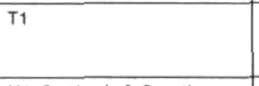 & $\begin{array}{llll} & \end{array}$ & T3: Posters & $\mathrm{T} 4$ & T5 & \\
\hline U: & $\begin{array}{l}\text { Amorphous \& } \\
\text { Nanostructured } \\
\text { Carbon }\end{array}$ & $\underset{(H)}{\operatorname{Room}} 311$ & $\begin{array}{l}\text { U1: Synthesis \& Growth } \\
\text { Mechanisms of Nanotubes }\end{array}$ & $\begin{array}{l}\text { U2: Structure \& Character- } \\
\text { ization of Nanotubes }\end{array}$ & & $\begin{array}{l}\text { U3: Electronic \& Mechanical } \\
\text { Properties of Nanotubes }\end{array}$ & $\begin{array}{l}\text { U4: Electron Emission } \\
\text { from Nanotubes \& } \\
\text { Amorphous Carbon }\end{array}$ & $\begin{array}{l}\text { U5-U8: } \\
\text { Posters }\end{array}$ \\
\hline v: & $\begin{array}{l}\text { Thin Films-Stresses } \\
\& \text { Mechanical Properties } \\
\text { VIII }\end{array}$ & $\underset{(H)}{R o o m ~} 306$ & & V1: Multilayered Films & & V2: Metallic Thin Films & \begin{tabular}{l|} 
V3: Epitaxy, Deposition \\
Parameters, Microstructure, \\
\& Stresses
\end{tabular} & V4: Posters \\
\hline W: & $\begin{array}{l}\text { GaN \& Related Alloys } \\
\text { Sunday Tutorial Session }\end{array}$ & $\underset{(H)}{\text { Room }} 302$ & W1: Optical Devices & $\begin{array}{l}\text { W2/O1: Lateral Epitaxial } \\
\text { Overgrowth }\end{array}$ & W3: Posters & $\begin{array}{l}\text { W4: Electronic Transport } \\
\text { \& Devices }\end{array}$ & $\begin{array}{l}\text { W5: Electronic \& Structural } \\
\text { Characterization }\end{array}$ & \\
\hline $\mathrm{x}:$ & $\begin{array}{l}\text { Frontiers of Materials } \\
\text { Research }\end{array}$ & $\begin{array}{c}\text { Room } 208 \\
(H)\end{array}$ & & $\begin{array}{l}\text { X1: MEDAL AWARD TALK } \\
\text { PRESENTATION } \\
\end{array}$ & & & $\mathrm{x} 2$ & \\
\hline $\mathrm{Y:}$ & $\begin{array}{l}\text { Ferroelectric Thin } \\
\text { Films VIII } \\
\text { Sunday Tutorial Session*. }\end{array}$ & $\underset{(H)}{\operatorname{Room}} 304$ & Y1: BST Thin Films \& DRAM & $\begin{array}{l}\text { Y2: Fundamental Properties } \\
\text { of Thin-Film Ferroelectrics }\end{array}$ & $\begin{array}{l}\text { Y3-Y6: } \\
\text { Posters }\end{array}$ & $\begin{array}{l}\text { Y7: Pb-Based Thin-Film } \\
\text { Ferroelectrics }\end{array}$ & $\begin{array}{l}\text { Y8: Bi-Based Thin-Film } \\
\text { Ferroelectrics }\end{array}$ & \\
\hline Z: & $\begin{array}{l}\text { Thin Films for Optical } \\
\text { Wavequide Devices }\end{array}$ & $\underset{(H)}{\text { Room }} 313$ & & & & & & \\
\hline AA: & $\begin{array}{l}\text { Matls. Sci. of Food- } \\
\text { Processing-Structure- } \\
\text { Property Relationships }\end{array}$ & $\begin{array}{l}\text { P'town/ } \\
\text { Orleans } \\
\text { (M) }\end{array}$ & & & & & & \\
\hline B8: & $\begin{array}{l}\text { Elec., Opt., \& Magnetic } \\
\text { Properties of Organic } \\
\text { Solid-State Matls. V }\end{array}$ & $\underset{(M)}{\text { Salon } G}$ & $\begin{array}{l}\text { 8B1: Molecular Engineering } \\
\text { \& Self-Assembly }\end{array}$ & B82: Light-Emitting Diodes & 8B3: Poslers & BB4: Nonlinear Optics & B85: Conducting Polymers & $\begin{array}{l}\text { 8B6: Evening } \\
\text { Session }\end{array}$ \\
\hline CC: & $\begin{array}{l}\text { Complex Fluids } \\
\text { \& Polymers }\end{array}$ & $\begin{array}{l}\text { Salon } J / K \\
(M)\end{array}$ & $\mathrm{CC} 1$ & $\mathrm{CC} 2$ & & $\mathrm{Cc} 3$ & $\mathrm{CC} 4$ & \\
\hline DD: & $\begin{array}{l}\text { Mineralization in } \\
\text { Natural \& Synthetic } \\
\text { Biomaterials }\end{array}$ & $\begin{array}{l}\text { Vineyard } \\
\text { (M) }\end{array}$ & $\begin{array}{l}\text { OD1: Bone \& Bonding of } \\
\text { Synthetic Materials to Bone } \\
\text { DD2: Cal. Phos. as Bone Sub. }\end{array}$ & $\begin{array}{l}\text { DD3: Biomimetic Apatite Coat. } \\
\text { DD4: Apatite Formation on } \\
\text { Inorganic Surfaces I }\end{array}$ & DD5: Posters & $\begin{array}{l}\text { DD6: Mineral Form. on Organic } \\
\text { Self-Assembled Surfaces I } \\
\text { DD7: Apatite Form. Inorg. Surf. II } \\
\end{array}$ & $\begin{array}{l}\text { DD8: Mineral Formation on } \\
\text { Organic Self-Assembled } \\
\text { Surfaces II }\end{array}$ & \\
\hline EE: & $\begin{array}{l}\text { Materials Science } \\
\text { of Phospholipid } \\
\text { Assemblies }\end{array}$ & $\begin{array}{l}\text { Salon } A / B \\
(M)\end{array}$ & $\begin{array}{l}\text { EE1: Lipid Monolayers, } \\
\text { Bilayers, \& Biomolecular } \\
\text { Interactions }\end{array}$ & EE2: Supported Membranes & & \begin{tabular}{|l|} 
EE3: PEG-Containing \\
Materials-Molecular \& \\
Biological Properties \\
\end{tabular} & $\begin{array}{l}\text { EE4: Drug \& Gene Delivery } \\
\text { VERMONT }\end{array}$ & EE5: Posters \\
\hline
\end{tabular}

$(\mathrm{H})=$ Hynes Convention Center
M) $=$ Boston Marriott Hotel

- All Evening Postor Sessions Located in Exhibition Hall $\mathrm{O}(\mathrm{H})$

* Check Tutorial Matrix in This Issue

Shadod Blocks: No Session 


\section{Symposium Session Locator}

\begin{tabular}{|c|c|c|c|c|c|c|c|}
\hline \multicolumn{3}{|c|}{ WEDNESDAY, DECEMBER 1} & \multicolumn{3}{|c|}{ THURSDAY, DECEMBER 2} & \multicolumn{2}{|c|}{ FRIDAY, DECEMBER 3} \\
\hline a.m. & p.m. & eve.* & a.m. & p.m. & eve.* & a.m. & p.m. \\
\hline $\begin{array}{l}\text { A4: Dislocation Dynamics- } \\
\text { Experiments \& Simulations }\end{array}$ & $\begin{array}{l}\text { A5: Dislocation Core } \\
\text { Properties \& Effects }\end{array}$ & A6: Posters & $\begin{array}{l}\text { A7: Fracture \& Crack } \\
\text { Propagation }\end{array}$ & $\begin{array}{l}\text { A8: Dislocation-Interface } \\
\text { Interactions }\end{array}$ & A9: Posters & & \\
\hline B3 & B4 & B5: Posters & 86 & $B 7$ & & & \\
\hline $\begin{array}{l}\text { D2: New Predictive } \\
\text { Descriptions of Materials }\end{array}$ & $\begin{array}{l}\text { D3: Prediction of Mechanical } \\
\text { Properties of Materials } \\
\end{array}$ & D4: Posters & $\begin{array}{l}\text { D5: Prediction of Electronic } \\
\text { Properties of Materials }\end{array}$ & $\begin{array}{l}\text { D6: Predictions over Large } \\
\text { Length and Time Scales }\end{array}$ & & $\begin{array}{l}\text { 07: Prediction of } \\
\text { Surface Phenomena }\end{array}$ & \\
\hline $\begin{array}{l}\text { E11: Particle Nucl. \& Growth I } \\
\text { E12: Particle Nucl. \& Growth II }\end{array}$ & $\begin{array}{l}\text { E13: Particle Nucl. \& Growth III } \\
\text { E14: Nanosystems }\end{array}$ & & & & & & \\
\hline $\begin{array}{l}\text { F6: Applications \& Properties of } \\
\text { Nanophase \& Nanocomposite } \\
\text { Materials I }\end{array}$ & $\begin{array}{l}\text { F7: Applications \& Properties of } \\
\text { Nanophase \& Nanocomposite } \\
\text { Materials II }\end{array}$ & F8: Posters & F9: Nanowires \& Nanospheres & $\begin{array}{l}\text { F10: Nanophase Metals } \\
\text { \& Simulation Studies }\end{array}$ & & & \\
\hline $\begin{array}{l}\text { G5: Nanoscale Ordering } \\
\text { \& Lithography via Polymer } \\
\text { Self-Assembly }\end{array}$ & $\begin{array}{l}\text { G6/H11: Nano- to Molec. Scale } \\
\text { Elec. of Organized Structures } \\
\text { G7/CC6: Nonlith. Approaches } \\
\text { SALON J/K } \\
\end{array}$ & G8: Posters & $\begin{array}{l}\text { G9: Surface-Induced } \\
\text { Organization }\end{array}$ & $\begin{array}{l}\text { G10: Field-Induced Order in } \\
\text { Structures \& Arrays }\end{array}$ & & $\begin{array}{l}\text { G11: } 20 \& 30 \\
\text { Photonic Structures }\end{array}$ & \\
\hline $\begin{array}{l}\mathrm{HO} \\
\mathrm{H} 10\end{array}$ & $\begin{array}{l}\text { H11/G6: Nano- to Molec. Scale } \\
\text { Elec. of Organized Structures } \\
\text { SALON E }\end{array}$ & & $\begin{array}{l}\mathrm{H} 12 \\
\mathrm{H} 13\end{array}$ & & & & \\
\hline $\begin{array}{l}\text { 15: Quantum Dots III / 3-D } \\
\text { Islanding }\end{array}$ & 16/N7: Atomic Scale Studies & 17: Posters & $\begin{array}{l}\text { I8/N9: Real-Time in-Situ } \\
\text { Studies on 3-D Islanding } \\
\text { DAVID TURNBUUL } \\
\text { AWARD LECTURE }\end{array}$ & & & & \\
\hline \multicolumn{8}{|l|}{$\begin{array}{l}\text { J5: Nonconventional } \\
\text { Lithographic Techniques }\end{array}$} \\
\hline $\begin{array}{l}\text { L5: Energetic Beam Effects } \\
\text { on Film Growth I }\end{array}$ & $\begin{array}{l}\text { L6: Energetic Beam Effects } \\
\text { on Film Growth II }\end{array}$ & & $\begin{array}{l}\text { L7: Surface Morphology } \\
\text { Evolution with Energetic } \\
\text { Beams }\end{array}$ & & & & \\
\hline $\begin{array}{l}\text { M1: General Concepts } \\
\text { \& Modeling }\end{array}$ & M2: Reactions \& Wetting & M3: Posters & $\begin{array}{l}\text { M4: Interface Structure/ } \\
\text { Composition/Character }\end{array}$ & M5: Mechanical Properties & & & \\
\hline $\begin{array}{l}\text { N5: Theory-Rate Equations } \\
\text { \& Monte Carlo } \\
\text { N6: Si Substrates }\end{array}$ & $\begin{array}{l}\text { N7/16: Atomic Scale Studies } \\
\text { WELLESLEY }\end{array}$ & N8: Posters & $\begin{array}{l}\text { N9/18: Real-Time In-Situ } \\
\text { Studies on } 3 \text {-D Islanding } \\
\text { WELLESLEY }\end{array}$ & $\begin{array}{l}\text { N10: Ab-Initio Methods } \\
\text { N11: Substrates-Eflects } \\
\text { \& Characterization } \\
\end{array}$ & & & \\
\hline O4: Wafer Bonding \& Lift-Off & $\begin{array}{l}\text { O5: Lattice Mismatch } \\
\text { Engineering ! }\end{array}$ & 06: Posters & $\begin{array}{l}\text { O7: Lattice Mismatch } \\
\text { Engineering II }\end{array}$ & $\begin{array}{l}\text { O8: Solid-Phase } \\
\text { Recrystallization } \\
\text { \& Eptaxy } \\
\end{array}$ & & ? & \\
\hline Q2: Crystallography \& Defects & Q3: Microelectronic Materials & $\begin{array}{l}\text { Q4. Q5: } \\
\text { Posters }\end{array}$ & $\begin{array}{l}\text { O6: Partially Ordered \& } \\
\text { Nanophase Materials }\end{array}$ & $\begin{array}{l}\text { Q7: Interfaces in } \\
\text { Metals \& Ceramics I }\end{array}$ & $\begin{array}{l}\text { Q8. Q9: } \\
\text { Posters }\end{array}$ & $\begin{array}{l}\text { Q10: Interfaces in } \\
\text { Metals \& Ceramics II }\end{array}$ & \\
\hline R6: X-Ray Diffraction & $\begin{array}{l}\text { R7: Micro-Diffraction } \\
\text { R8: Micro-Tomography/ } \\
\text { Phase Contrast }\end{array}$ & R9: Posters & $\begin{array}{l}\text { R10: Thermoelec. \& Mag. Matts.: } \\
\text { X-Ray Photoemission, Stand. } \\
\text { Waves, \& Nuc. Res. Spec. I } \\
\text { R11: (Cont'd.) II }\end{array}$ & $\begin{array}{l}\text { R12: X-Ray Absorption } \\
\text { Spectroscopy of Magnetic } \\
\text { Materials \& Nanoparticles I } \\
\text { R13:(Cont'd.) II }\end{array}$ & & $\begin{array}{l}\text { R14: X-Ray Absorption } \\
\text { Spectroscopy }\end{array}$ & \\
\hline \multicolumn{8}{|l|}{ T6 } \\
\hline $\begin{array}{l}\text { U9: Applications of Amorphous \& } \\
\text { Nanostructured Carbon-Elec- } \\
\text { trical, Chemical, \& Mechanical }\end{array}$ & $\begin{array}{l}\text { U10N7: Mechanical } \\
\text { Properties of Amorphous } \\
\text { \& Crystalline Carbon } \\
\end{array}$ & & $\begin{array}{l}\text { U11: Structural Characterization } \\
\text { of Amorphous Carbon }\end{array}$ & $\begin{array}{l}\text { U12: Deposition \& } \\
\text { Electrical Properties of } \\
\text { Amorphous Carbon }\end{array}$ & & & \\
\hline $\begin{array}{l}\text { V5/MM10: Thin Films } \\
\text { for Applications in MEMS } \\
\text { V6: Polymer Thin Films } \\
\end{array}$ & $\begin{array}{l}\text { V7/U10: Mechanical } \\
\text { Properties of Amorphous } \\
\text { \& Crystalline Carbon } \\
\text { RoOM } 311 \\
\end{array}$ & & V8: Adhesion \& Fracture & $\begin{array}{l}\text { V9: Reliability in } \\
\text { Microelectronics }\end{array}$ & V10: Posters & $\begin{array}{l}\text { V11: Nanoindentation } \\
\text { \& Advanced Testing } \\
\text { Techniques }\end{array}$ & \\
\hline $\begin{array}{l}\text { W6: Growh-MOCVD, } \\
\text { HVPE, BULK }\end{array}$ & $\begin{array}{l}\text { W7: Panel Discussion 1:30-3pm } \\
\text { WB: Growh-MBE, Cubic GaN, } \\
\text { GaAsN, Si Substrates }\end{array}$ & & W9: Theory, Doping & $\begin{array}{l}\text { W10: Contacts, Point } \\
\text { Defects, Processing }\end{array}$ & $\begin{array}{l}\text { W11: } \\
\text { Posters }\end{array}$ & $\begin{array}{l}\text { W12: Quantum Dots, Optical } \\
\text { Characterization, Rare Earths }\end{array}$ & \\
\hline$x$ & $\begin{array}{l}\text { X3: MEDAL AWARD TALK } \\
\text { PRESENTATION }\end{array}$ & & & $x_{4}$ & & & \\
\hline Y9: Integration \& Electrodes & $\begin{array}{l}\text { Y10/KK4: High-Frequency } \\
\text { Applications of Ferroelectrics }\end{array}$ & $\begin{array}{l}\text { Y11-Y14: } \\
\text { Y15KK5: } \\
\text { Posters } \\
\end{array}$ & $\begin{array}{l}\text { Y16: Fundamental Properties } \\
\text { of Thin-Film Ferroelectrics } \\
\text { \& Ferroelectric Gate Materials } \\
\end{array}$ & $\begin{array}{l}\text { Y17: Piezoelectric Thin Films \& } \\
\text { Thin-Film Capacitor Malerials }\end{array}$ & & & \\
\hline $\begin{array}{l}\text { Z1: Luminescent Waveguide } \\
\text { Materials \& Devices }\end{array}$ & $\begin{array}{l}\text { 22: Planar Optics on } \mathrm{Si} \\
\text { \& Photonic Crystals } \\
\end{array}$ & & $\begin{array}{l}\text { 23: Polymers-Material } \\
\text { Property \& Photonic Devices }\end{array}$ & Z4: Inorganic Films \& Devices & Z5: Posters & & \\
\hline AA1 & $\begin{array}{l}\text { AA2 } \\
\text { AA3: In-Room Posters } \\
\text { FALMOUTH }\end{array}$ & & AA4 & AA5 & & & \\
\hline $\begin{array}{l}\text { BB7/PP3: Two-Photon } \\
\text { Absorption \& Applications }\end{array}$ & B88: Organic Photonics & & BB9: Semiconducting Polymers & BB10: Light-Emitting Diodes & $\begin{array}{l}\text { B811: } \\
\text { Posters }\end{array}$ & $\begin{array}{l}\text { BB12/PP7: Organic } \\
\text { Photorefractives }\end{array}$ & \\
\hline CC5 & $\begin{array}{l}\text { CC6/G7: Nonlithographic } \\
\text { Approaches }\end{array}$ & & $\mathrm{CC} 7$ & $\mathrm{CC} 8$ & \begin{tabular}{|l|} 
CC9: \\
Posters \\
\end{tabular} & CC10 & \\
\hline $\begin{array}{l}\text { DD9: Path. Mineral. \& Prevention } \\
\text { DD 10; Calcium Carbonate } \\
\text { Formation }\end{array}$ & $\begin{array}{l}\text { DD11: Biomimetic Hydroxy- } \\
\text { apatite-Polymer Composite } \\
\text { DD12: Biomol.-Mineral Interact. }\end{array}$ & & & & & & \\
\hline $\begin{array}{l}\text { EE6: Tubules, Templates, } \\
\text { \& Polymerization } \\
\text { VERMONT } \\
\end{array}$ & & & & & & & \\
\hline
\end{tabular}




\section{Symposium Session Locator}

\begin{tabular}{|c|c|c|c|c|c|c|c|c|}
\hline & \multirow[t]{2}{*}{ SYMPOSIUM } & \multirow[t]{2}{*}{ LOCATION } & \multicolumn{3}{|c|}{ MONDAY, NOVEMBER 29} & \multicolumn{3}{|c|}{ TUESDAY, NOVEMBER 30} \\
\hline & & & a.m. & p.m. & eve.* & a.m. & p.m. & eve." \\
\hline F: & $\begin{array}{l}\text { Electroactive Polymers } \\
\text { Sunday Tutorial Session"* }\end{array}$ & $\underset{(M)}{\text { Simmons }}$ & FF1 & $\mathrm{FF} 2$ & FF3: Posters & FF4 & FF5 & \\
\hline GG: & $\begin{array}{l}\text { Transport Properties } \\
\& \text { Microstructure of } \\
\text { Cement-Based Systems }\end{array}$ & $\begin{array}{c}\text { Room } 207 \\
(H)\end{array}$ & GG1: Microstructure & GG2: Transport I & & GG3: Transport II & $\begin{array}{l}\text { GG4/OO6: Cement-Based } \\
\text { Matls. \& Waste Containment } \\
\text { ROOM 203 }\end{array}$ & \\
\hline $\mathrm{HH}$ & $\begin{array}{l}\text { Superplasticity- } \\
\text { Current Status \& } \\
\text { Future Potential }\end{array}$ & $\underset{(H)}{R o o m} 204$ & $\begin{array}{l}\text { HH1: Superplasticity } \\
\text { in Metals }\end{array}$ & $\begin{array}{l}\text { HH2: Superplasticity } \\
\text { in Industry }\end{array}$ & & $\begin{array}{l}\text { HH3: Superplasticity } \\
\text { in Ceramics }\end{array}$ & $\begin{array}{l}\text { HH4: Other Techniques } \\
\text { Including Severe Plastic } \\
\text { Deformation }\end{array}$ & \\
\hline II: & $\begin{array}{l}\text { Superconduct. Matls.- } \\
\text { Prop/Crys. Chem/Proc. } \\
\text { Sunday Tutorial Session"* }\end{array}$ & $\begin{array}{l}\text { Room } 200 \\
(H)\end{array}$ & $\begin{array}{l}\text { 111: Crystal Chemistry } \\
\text { \& New Materials I }\end{array}$ & $\begin{array}{l}\text { 112: Crystal Chemistry } \\
\text { \& New Materials II }\end{array}$ & 113: Posters & $\begin{array}{l}\text { 114/22/O2: Biaxially Textured } \\
\text { Substrates for High- } \mathrm{T}_{\mathrm{e}} \text { Coated } \\
\text { Conductors }\end{array}$ & $\begin{array}{l}115: \text { Phase Equilibria, } \\
\text { Thermodynamics, \& } \\
\text { Kinetics } \\
\end{array}$ & \\
\hline J): & $\begin{array}{l}\text { Magnetoresistive } \\
\text { Oxides and Related } \\
\text { Materials }\end{array}$ & $\underset{(H)}{\operatorname{Room}} 202$ & $\begin{array}{l}\text { JJ1: Spin Polarization } \\
\text { \& Tunnelling in Magnetic } \\
\text { Oxides } \\
\end{array}$ & JJ2: Novel Magnetic Oxides & JJ3: Poster & $\begin{array}{l}\text { JJ4: Transport \& } \\
\text { Optical Properties }\end{array}$ & $\begin{array}{l}\text { JJ5: Charge \& Orbital } \\
\text { Ordering Effects }\end{array}$ & \\
\hline KK: & $\begin{array}{l}\text { Materials issues } \\
\text { for Tunable RF \& } \\
\text { Microwave Devices }\end{array}$ & $\begin{array}{c}\text { Room } 201 \\
(\mathbf{H})\end{array}$ & & & & $\begin{array}{l}\text { KK1: Frequency Agile } \\
\text { Materials for Electronics }\end{array}$ & KK2: Electric-Field Tuning & \\
\hline LL: & Smart Materials & $\underset{(H)}{R o o m} 309$ & & & & LL1: Piezoelectrics I & WL2: Piezoelectrics II & \\
\hline MM: & $\begin{array}{l}\text { Matls. Science of Micro- } \\
\text { electromechanical Sys- } \\
\text { tem (MEMS) Devices II } \\
\text { Sunday Tutorial Session"* }\end{array}$ & $\underset{(H)}{\text { Room } 313}$ & $\begin{array}{l}\text { MM1: Deposition \& Char- } \\
\text { acterization of Silicon I- } \\
\text { MM2: Deposition \& Char- } \\
\text { acterization of Silicon II }\end{array}$ & $\begin{array}{l}\text { MM3: New Materials \& } \\
\text { Processes for MEMS I } \\
\text { MM4: New Materials \& } \\
\text { Processes for MEMS il }\end{array}$ & MM5: Posters & $\begin{array}{l}\text { MM6: LIGA } \\
\text { MM7: MEMS Tribology }\end{array}$ & $\begin{array}{l}\text { MM8: New Characterization } \\
\text { Techniques/MEMS Devices } \\
\text { MM9: MEMS Packaging }\end{array}$ & \\
\hline NN: & $\begin{array}{l}\text { Chemical Processing of } \\
\text { Dielectrics, Insulators, } \\
\text { \& Electronic Ceramics }\end{array}$ & $\begin{array}{c}\text { Room } 312 \\
(H)\end{array}$ & NN1: Oxides & NN2: Dielectrics & NN3: Posters & NN4: Ferroelectrics & $\begin{array}{l}\text { NN5: Batteries/Fuel Cells } \\
\text { NN6: Solar Cells }\end{array}$ & $\begin{array}{l}\text { NN7-NN9: } \\
\text { Posters }\end{array}$ \\
\hline O०: & $\begin{array}{l}\text { Infrared Applications of } \\
\text { Semiconductors III }\end{array}$ & $\underset{(H)}{\text { Room }} 206$ & $\begin{array}{l}\text { O01: Antimonide-Related } \\
\text { Materials \& Devices I } \\
\end{array}$ & $\begin{array}{l}\text { O02: Antimonide-Related } \\
\text { Materials \& Devices II }\end{array}$ & & 003: Innovative Devices I & O04: Innovative Devices II & OO5: Posters \\
\hline PP: & $\begin{array}{l}\text { Materials for Optical } \\
\text { Limiting III }\end{array}$ & $\begin{array}{l}\text { Room } 205 \\
\text { (H) }\end{array}$ & & & & & $\begin{array}{l}\text { PP1: RSA \& Multichromo- } \\
\text { phore Materials }\end{array}$ & PP2: Posters \\
\hline QQ: & $\begin{array}{l}\text { Scientific Basis for } \\
\text { Nuclear Waste } \\
\text { Management XXIII }\end{array}$ & $\underset{(H)}{\text { Room }} 203$ & QQ1: Cladding \& Spent Fuel & $\begin{array}{l}\text { QQ2: Flow \& Transport } \\
\text { QQ3: Interfacial Processes } \\
\text { \& Interactions }\end{array}$ & & $\begin{array}{l}\text { QQ4: Ceramics-Corrosion } \\
\text { QQ5: Ceramics-Structure } \\
\text { \& Characterization }\end{array}$ & $\begin{array}{l}\text { OQ6/GG4: Cement- } \\
\text { Based Materials \& } \\
\text { Waste Containment }\end{array}$ & $\begin{array}{l}\text { QQ7-QQ15: } \\
\text { Posters }\end{array}$ \\
\hline
\end{tabular}

(B) = Hyme Convention Center

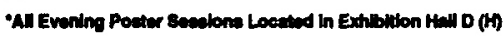

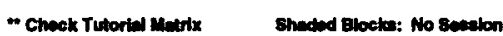

\section{Symposium Tutorials}

(Details avallable on the MRS Web site and in the Program Book)

\section{SUNDAY + NOVEMBER 28}

\section{Symposium d}

FT): Advanced Resists for Micro- and Nanolithography

2:00 - 5:00 p.m Room 204

Hynes Convention Center

\section{Symposium FF}

FTf: Electroactive Polymers as Emerging Actuators for Devices and Robotic Applications

1:30 - 5:00 p.m.

Room 206

Hynes Convention Center

\section{Symposium 4}

FTW: Material Characteristics

of the III-Nitrides

2:00 - 5:00 p.m.

Room 202

Hynes Convention Center

\section{Symposium II}

FTI: Fundamental Material

Aspects of High-Temperature

Superconductors

1:00-5:00 p.m.

Room 200

Hynes Convention Center

\section{MONDAY • NOVEMBER 29}

\section{Symposium L}

FT: Low-Energy lon and Hyperthermal Meutral Beams for Semiconductor, Metal, and Ceramic Film Growth

8:30 a.m. $-12: 00$ p.m.

Salon H/l - Marriott
Symposium Y
FTr: Ferroelectric Thin Fllms

1:00 - 5:00 p.m Room 203

Hynes Convention Center

\section{Symposium MM}

FTm: Polycrystalline Silicon and Silicon Carbide as Materials for MEMS

9:00 a.m. - 4:00 p.m. Room 201

Hynes Convention Center
Tutorial attendance is open to all meeting registrants at no extra charge. 


\section{Symposium Session Locator}

\begin{tabular}{|c|c|c|c|c|c|c|c|}
\hline \multicolumn{3}{|c|}{ "WEDNESDAY, DECEMBER 1} & \multicolumn{3}{|c|}{ THURSDAY, DECEMBER 2} & \multicolumn{2}{|c|}{ FRIDAY, DECEMBER 3} \\
\hline a.m. & p.m. & eve. ${ }^{*}$ & a.m. & p.m. & eve.* & a.m. & p.m. \\
\hline FF6 & FF7 & & & & & & \\
\hline $\begin{array}{l}\text { HH5: Fundamental Aspects } \\
\text { of Superplasticity }\end{array}$ & $\begin{array}{l}\text { HH6: High-Strain-Rate } \\
\text { Superplasticity }\end{array}$ & & & & & & \\
\hline II6: Critical Currents & 117: Coated Conductors & & 118: HTS Film Growth & $\begin{array}{l}\text { 119: BScCo Processing } \\
\text { \& Properties }\end{array}$ & II10: Posters & $\begin{array}{l}\text { II11: Bi-, Th, \& Hg-Containing } \\
\text { Superconductors- } \\
\text { Processing \& Properties }\end{array}$ & \\
\hline $\begin{array}{l}\text { JJ6: Two-Phase Coexistence in } \\
\text { the Manganites }\end{array}$ & $\begin{array}{l}\text { JJJ7: Strain Effects in Manganite } \\
\text { Thin Films }\end{array}$ & JJ8: Posters & $\begin{array}{l}\text { Jjg: Magnetic Oxide Thin } \\
\text { Films \& Heterostructures }\end{array}$ & $\begin{array}{l}\text { JJ10: Magnetic Oxide } \\
\text { Heterostructures \& Devices }\end{array}$ & & & \\
\hline KK3: Magnetic-Field Tuning & $\begin{array}{l}\text { KK } 4 / Y 10: \text { High-Frequency } \\
\text { Applications of Ferroelectrics } \\
\text { ROOM } 304\end{array}$ & $\begin{array}{l}\text { KK5/ 15, KK6: } \\
\text { Posters }\end{array}$ & KK7: Fundamentals & $\begin{array}{l}\text { KK8: Malerials } \\
\text { Characterizations }\end{array}$ & & & \\
\hline LL3: Shape Memory & LL4: Actuator Materials & LL5: Posters & LL6: Magnetostrictive Materials & $\begin{array}{l}\text { LL7: Sensor \& } \\
\text { Other Materials }\end{array}$ & & & \\
\hline $\begin{array}{l}\text { MM10N5: Thin Films } \\
\text { for Applications in MEMS } \\
\text { ROOM } 306\end{array}$ & & & & & & & \\
\hline $\begin{array}{l}\text { NN10: Ceramics } \\
\text { NN11: SiC \& Diamonds } \\
\text { NN12: Polymers }\end{array}$ & & & & & & & \\
\hline $\begin{array}{l}\text { O06: Growth, Char., Inn. Tech. } \\
\text { OO7: Infrared Photodelectors }\end{array}$ & $\begin{array}{l}\text { OOB: Innovative Materials } \\
\text { \& Devices }\end{array}$ & & 009: Nonlinear Optical Materials & $\begin{array}{l}\text { O010: Interdiffusion } \\
\text { in Quantum Wells }\end{array}$ & & & \\
\hline $\begin{array}{l}\text { PP3/BB7: Two-Photon } \\
\text { Absorption \& Applications } \\
\text { SALON G }\end{array}$ & $\begin{array}{l}\text { PP4: Two-Photon Absorbers \& } \\
\text { Spectroscopy of Optical Limiting }\end{array}$ & & PP5: Theory \& Modeling & $\begin{array}{l}\text { PP6: Liquid Crystals, } \\
\text { Nanotubes, \& } \\
\text { Photorefractives }\end{array}$ & & $\begin{array}{l}\text { PP7/BB12: Organic } \\
\text { Photorefractives } \\
\text { SALON G }\end{array}$ & \\
\hline QQ16: Containers \& Repository & $\begin{array}{l}\text { QQ17: Use of Natural Analog } \\
\text { Info, in Performance Assessment } \\
\text { QQ18: Microbial Processes } \\
\text { in Waste Management }\end{array}$ & & $\begin{array}{l}\text { QQ19: Glass-Processing } \\
\text { \& Characterization } \\
\text { OQ20: Glass-Corrosion } \\
\text { \& Characterization }\end{array}$ & QQ21: Waste Processing & & & \\
\hline
\end{tabular}

\section{MRS Fall Meeting}

\section{Hotel Reservations}

A block of rooms has been reserved for MRS meeting attendees at the Boston Marriott, Westin, Sheraton Boston, and Back Bay Hilton Hotels. When making your reservations, mention the Materials Research Society's meeting to receive the special rate. A hotel reservation form is available on the MRS Web site (www.mrs.org) and in the Program Book.

\section{DEADLINE FOR HOTEL RESERVATIONS: November 8, 1999} Rooms are limited - reserve yours early!

\section{Boston Marriott/Copley Place}

110 Huntington Avenue, Boston, MA 02116 $800-228-9290 \cdot 617-236-5800$ (Direct)

Fax 617-578-0685

Room Rate: $\$ 130$ Single $* \$ 144$ Double*

\section{Westin Hotel/Copley Place}

10 Huntington Avenue, Boston, MA 02116 800-937-8461 - 617-262-9600 (Direct)

Fax 617-424-7502

Room Rate: \$133 Single* • \$150 Double*

Sheraton Boston Hotel and Towers

39 Dalton Street, Boston, MA 02199

617-236-2020

Fax 617-236-1702

Room Rate: \$123 Single* • \$134 Double*

Back Bay Hilton

40 Dalton Street, Boston, MA 02115

617-236-1100

Fax 617-867-6139

Room Rate: $\$ 130$ Single* • \$145 Double *

" plus Massachusetts tax, currently $12.45 \%$
Transportation

\section{Airline Transportation}

This fall MRS is offering special, discounted airfares through a designated travel agency as a service to MRS Fall Meeting attendees. Refer to the MRS Web site (www.mrs.org) or the Program Book for the Discount Air Fare Form.

\section{Local Transportation}

Taxicabs are available around the clock. Fares range from $\$ 10-\$ 15$ to the Back Bay area hotels.

City Transportation Service, 617-321-2282, is located outside the baggage claim areas at the airport and stops at various Boston hotels. The fare is $\$ 7.50$ per person one way. The shuttle departs every half hour, Sunday through Friday, 7:00 a.m.-10:00 p.m.; on Saturday, every hour, 8:00 a.m.-8:00 p.m.

For more information on other ground transportation to and from Logan International Airport, call MASSPORT, 24 hours a day, at 1-800-23-LOGAN.

\section{Parking}

Parking costs in the city range from $\$ 15-\$ 25$ per day. Parking is available in the garage between the Boston Marriott and the Westin Hotels at Copley Place. There is also parking at the Prudential Center Complex.

\section{Ghild Care}

Check with the Concierge Desk at the indlvidual hotels for a comprehensive roster of licensed and bonded sitters. 


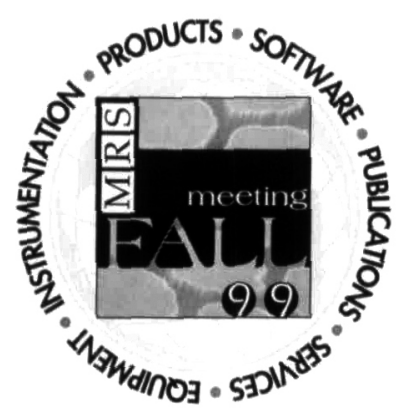

Exhibit Hours:

Tuesday, November 30

Wednesday, December 1

Thursday, December 2
11:30 am - 6:00 pm

9:00 am - 6:00 pm

9:00 am - 2:00 pm
The MRS Fall Exhibit offers everything you need... all under one roof!
The MRS Exhibit, held in conjunction with the 1999 MRS Fall Meeting, will feature more than 225 international exhibitors from all sectors of the global materials science and engineering communities. Learn about the latest techniques, advances, and the future of materials science and engineering directly from the manufacturers, suppliers and developers. Or browse the new releases, publications and journals from the various publishers. As always, the exhibit is convenient to the technical session rooms and scheduled to coincide with the program. Complimentary coffee will be available during morning and afternoon breaks in the exhibit hall.

\section{A \& N Corporation \#306}

707 Southwest 19 th Avenue Williston, FL 32696

Tel: $352-528-4100$

Toll Free: 800-FLANGE-1

Fax: 352-528-3441

E-mail: info@ancorp.com

www.ancorp.com

A \& N Corporation has been a manufacturer of high-quality vacuum components for over 30 years. Our product line includes flanges and fittings in the following styles: ISO-KF (QF), ISO-MF (LF), UHV (CF), ASA, tri-seal, vacuum couplings, feed throughs, vacuum ball valves, and special fabrications. New for 1999: right angle valves, in-line valves, gate valves, and vacuum line heaters/controllers.

\section{- ABB Extrel \#1003}

575 Epsilon Drive

Pittsburgh, PA 15238-2838

Tel: $412-967-5752$

Fax: 412-963-6578

E-mail: qms@extrel.com www.abb.com/extrel

ABB Extrel has been manufacturing quadrupole mass spectrometers and systems since 1964 . Our instruments' high sensitivity and resolution allows us to monitor and control processes that simple residual gas analysis (RGA) cannot detect. We place special emphasis on plasma and CVD, SIMS, molecular beam, environmental abatement, and high-purity gas applications.

\section{Academic Press \#1024 \\ 525 B Street, Suite 1900 \\ San Diego, CA 92101 \\ Tel: 800-321-5068 \\ Fax: 800-874-6418 \\ E-mail: ap@acad.com \\ www.academicpress.com}

Visit Academic Press to browse our outstanding selection of new and recent titles including:

Electrodynamics of Materials, Experimental Methods in Polymer Science, Intersubband Transitions in Quantum Wells, Chemical Mechanical Polishing in Silicon Processing, Handbook of Giant Magnetorestrictive Materials, Optical Properties of Materials, Handbook of Low and High Dielectric Constant Materials, Handbook of Nanostructured Materials, Handbook of Superconductivity, Solid State Physics, Database of Palladium Chemistry Version 1.1, Adsorption by Powders of Porous Solids, Cracks and Fractures. Journals on display include Superlattices and Microstructures and Journal of Chemical Thermodynamics. Substantial discounts offered on all books purchased at the booth.

\section{Advanced Control Systems Corporation \#100 \\ 10 Old Mine Rock Way \\ Hingham, MA 02043 \\ Tel: 781-740-0223 \\ Fax: 781-740-4227 \\ E-mail: info@acsmotion.com \\ www.acsmotion.com}

Manufacturer of stepping motor control systems. Standard products include drivers for two, three, four and five phase motors, up to eight channel indexers and power supplies. High reliability, efficiency and low noise operation are our specialty. Custom built systems also available.
Advanced Research Systems, Inc. $\# 600,602$

905 Harrison Street, Suite 109

Allentown, PA 18103

Tel: $610-439-8022$

Fax: $610-439-1184$

E-mail: arscryo@aol.com Advanced Research Systems, Inc. offers a complete range of laboratory cryogenic systems for low temperature research. Products include the Displex ${ }^{\circledR}$, closed-cycle systems from a temperature range of $6.5 \mathrm{~K}$ to $800 \mathrm{~K}$ for spectroscopy (UV, Vis, IR and Raman), transport, $x$-ray diffraction, UHV, etc. ARS also sells the Helitran ${ }^{\circledR}$, flow cryostats for all research applications as well. Advanced Research Systems is uniquely qualified to offer customized cryostats as well as cryogenic accessories.

\section{AIXTRON, Inc. \#304}

1670 Barclay Blvd.

Buffalo Grove, IL 60089

Tel: 847-215-7335

Fax: 847-215-7341

AIXTRON is the world leading manufacturer of MOCVD and VPE equipment for the growth of all III-V, including nitrides, II-VI, oxides and $\mathrm{SiC}$. Systems are manufactured with outstanding quality and care, with excellent reliability, and with award-winning technical and service support. Systems include: AIX-200; AIX200/4; AIX-2400; the world's largest, the AIX-3000; and the new, automated $2600 \mathrm{G} 3$.

\section{AJA International, Inc. \#313 \\ P.O. Box 246 \\ 809 Country Way \\ N. Scituate, MA 02060 \\ Tel: 781-545-7365 \\ Fax: 781-545-4105 \\ E-mail: topgun@ajaint.com www.ajaint.com}

Product line includes: circular and rectangular magnetron sputtering sources and targets, ATC R\&D sputtering systems, substrate heaters, $R F$ and DC power supplies, microwave power supplies and components, microwave plasma sources (downstream, surfaguide, SLAN, surfatron), diamond film equipment, electrostatic chucks and ESC power supplies.

\section{- Akzo Nobel Chemicals Inc. \#220 \\ 300 South Riverside Plaza Chicago, IL 60606 \\ Tel: 800-828-7929 \\ Fax: 312-906-7633 \\ E-mail: metalorganics@ akzonobel.com \\ www.akzonobel.com}

Akzo Nobel metalorganics meet your III-V deposition needs from antimony to zinc. Our completely modernized and expanded production facilities utilize all in-plant manufactured raw materials for advanced quality and inventory control. Proprietary purification and analysis techniques effectively eliminate silicon and oxygen without introducing adducts. Akzo Nobel FT-NMR oxygen monitoring is an industry benchmark. Visit our exhibition booth for more information on Akzo Nobel ultra-low oxygen and silicon sources including trimethylgallium, trimethylindium, and trimethylaluminum. 
Alcatel Vacuum Products, Inc. \#219

67 Sharp Street

Hingham, MA 02043

Tel: $781-331-4200$

Fax: 781-331-4230

Manufactures a complete and comprehensive range of DRY pumps and pumping systems, ceramic ball bearing, turbomolecular pumps,

DRYTEL pumping systems, maglev turbomolecular pumps, helium leak detector line (including cleanroom, compatible dry leak detectors), rotary vane direct drive pumps and blower packages, valves, gauges and accessories.

\section{- Aldrich Chemical Company. Inc. \#1020 \\ P.O. Box 355 \\ Milwaukee, WI 53201 \\ Tel: 414-298-7910 \\ Fax: 414-298-7960 \\ E-mail: crecatto@sial.com www.sigma-aldrich.com}

Aldrich produces and stocks a comprehensive range of chemical products including, but not limited to, OMCVD precursors, metal alkoxides, metal B-diketonates, CVD gases, high purity metals, battery materials, conducting polymers, anhydrous metal halides, organic photonic materials, dopant/intercalation compounds, sol-gel compounds, catalysts, silsesquioxanes, hyperbranched polymers, superconductor precursors, ACS reagents and analytical standards. These products are used in scientific research, product development, testing, and analysis in the various fields encompassing materials research.

\section{- Alfa Aesar \#907}

A Johnson Matthey Company 30 Bond Street

Ward Hill, MA 01835

Tel: 978-521-6300

Toll Free: $800-343-0660$ (catalog sales)

Toll Free: 888-343-8025 (bulk/special sales)

Fax: 978-521-6350

E-mail: info@alfa.com www.alfa.com

Alfa Aesar, a Johnson Matthey Company, is a leading manufacturer and supplier of research chemicals, metals and materials. Our product line includes fabricated metals from aluminum to zirconium, offered in a comprehensive range of forms (sheet, wire, rod, targets, etc.). Other products include inorganic and organic research chemicals, pure elements, alloys, precious metal compounds and catalysts, rare earths, analytical products and more. Products are available from our two catalogs (which combine to offer over 22,000 products) or through our Specialty Group which supplies larger quantities or products that are not listed in the catalogs. Visit our booth for a copy of our new periodic table desk reference featuring the recently named elements.

\section{Altran Corporation \#209 \\ 451 D Street}

Boston, MA 02210

Tel: $617-204-1000$

Fax: 617-204-3080

E-mail: takeuchi@altran.com www.altran.com

Altran Corporation is a consulting engineering firm with over a decade of experience working with qualitysensitive industries such as nuclear and medical. Altran's engineers span a range of disciplines including biomedical, chemical, civil, electrical, mechanical, metallurgical and polymer engineering. Our specific engineering services include forensic analysis (metallography, optical/electron microscopy, EDS, WDS, XRD, AAS, GCMS, FTIR, DSC, etc.), testing services (corrosion, fatigue, fracture, microbiology, product simulations, etc.), and design/engineering services (FEA, CFD, product development, systems analysis, etc.). Over 150 professionals are located in Boston (headquarters and materials laboratory), Charlotte, San Francisco, and Toronto.

\section{American Chemical Society \#826 1155 Sixteenth Street N.W. \\ E-mail: gdriscoll@amsuper.com www.amsuper.com} Washington, DC 20036

Tel: $202-872-4600$

Fax: 202-872-4615

E-mail: help@acs.org pubs.acs.org

Display includes American Chemical Society publications relevant to the field of materials science. Both print and web editions are available for Chemistry of Materials, Macromolecules, Langmuir, Journal of Combinatorial Chemistry, Industrial \& Engineering Chemistry Research, and The Journal of Physical Chemistry (both editions). Web edition special features will be demonstrated.

\section{American Institute of Physics} \#1026

2 Huntington Quadrangle, Suite 1N01

Melville, NY 11747-4502

Tel: 516-576-2484

Fax: 516-576-2374

E-mail: corr@aip.org

www.aip.org

Save up to $40 \%$ off our already low member and affiliate society rates with new online-only journal subscriptions from AIP. Learn more about SPIN Web, our latest portal to the powerful SPIN database. And don't forget to pick up your free sample copy of Computing in Science and Engineering, the new magazine published by AIP and IEEE Computer Society.

\section{The American Physical Society \#822}

One Physics Ellipse

College Park, MD 20740-3844

Tel: 301-209-3283

Fax: 301-209-0844

E-mail: assocpub@aps.org publish.aps.org

Explore Physical Review Online base containing full 1985-1996 Physical Review articles. Come see also APS online research journals and publications: Physical Review A-E, Physical Review Letters, Reviews of Modern Physics, Physical Review Special Topics-Accelerators and Beams, and Physical Review Focus.

\section{American Superconductor \#207}

2 Technology Drive

Westborough, MA 01581-1727

Tel: 508-836-4200

Fax: 508-836-4714

American Superconductor will be displaying its full line of HTS current leads. American Superconductor has recently purchased AET and will also be displaying their full cryogenic product line. Information will be available on American Superconductor's SMES units as well information on ongoing HTS motor and HTS cable programs. Archive (PROLA), an archival data-
- Andeen-Hagerling, Inc. \#425

31200 Bainbridge Road

Cleveland, $\mathrm{OH}$ 44139-2231

Tel: 440-349-0370

Fax: 440-349-0359

E-mail: info@andeenhagerling.com

www.andeen-hagerling.com

Manufacturers of ultra-precision capacitance bridges and standards. The AH 2500A/Option E automatic capacitance/loss bridge can resolve to 0.5 attofarad and measure loss down to a dissipation factor of $1.5 \times 10^{-8} \delta$ tan at $1 \mathrm{KHz}$. An automatic, multi-frequency bridge ( 50 $\mathrm{Hz}$ to $20 \mathrm{KHz}$ ), with an analog output, is near completion (AH2700A).

Angstrom Sciences, Inc. \#509

40 South Linden Street

Duquesne, PA 15110

Tel: $412-469-8466$

Fax: 412-469-8511

E-mail: sales@angstrosciences.com www.angstromsciences.com Angstrom Sciences specializes in the design and manufacture of the ONYX ${ }^{\mathrm{TM}}$ high performance magnetron sputtering cathodes for both research and development and production applications. Angstrom Sciences also provides a complete line of sputtering targets, evaporation materials, target backing plates and target bonding services. Angstrom Sciences has the experience and technology to assist you in achieving your process requirements.

\section{Applied Nano Metrics, Inc.} \#1211

P.O. Box 26

605 Eder Road

Stormville, NY 12582

Tel: 914-226-6961

Fax: 914-226-8381

E-mail: info@appliednano.com www.appliednano.com

Need to know the hardness or elastic modulus of a thin coating or small volume? Applied Nano Metrics, Inc. is a service laboratory that specializes in nanoindentation and other small-scale mechanical tests. Call us to discuss your application or visit us on the web at www.appliednano.com! 


\section{Applied Surface Technologies $\# 620$}

15 Hawthorne Drive

New Providence, NJ 07974

Tel: 908-464-6675

Fax: 908-464-7475

E-mail: co2clean@aol.com www.co2clean.com

The $\mathrm{CO} 2$ Snow Jet will be demonstrated. The Snow Jet cleaning process is a simple, yet novel, surface cleaning process that can remove particles of all sizes and also organic residues from surfaces. The process works well for many substrates, vacuum parts, analytical samples (AFM, XPS, AES), and many other applications. The Snow Jet process is, nondestructively, residue-free with no environmental limitations.

Avanti Polar Lipids, Inc. \#218 700 Industrial Park Drive Alabaster, AL 35007

Tel: 205-663-2494

Fax: 205-663-0756

E-mail: avanti@quicklink.net www.avantilipids.com

For 30 years Avanti has been supplying the research and pharmaceutical community with high purity lipids for biomedical applications. Since we have extensive experience in the production and quality control of phospholipids, and have knowledge of the physical and chemical properties of these products, we will have answers to solve your phospholipid problems.

\section{- Bede Scientific Incorporated $\# 901,903$}

14 Inverness Drive East
Suite G-104
Englewood, CO 80112
Tel: $303-790-8647$
Fax: $303-790-8648$
E-mail: info@bede.com
www.bede.com

Bede Scientific is a world leader in materials characterization, established for 20 years in high resolution $x$-ray diffraction and scattering techniques, largely in the semiconductor industry. Bede developed the world's first commercial computercontrolled high resolution diffractometers and reflectometers, comprehensive Windows analytical software including novel automated parameter extraction using genetic algorithms, the new highly versatile D1 diffractometer with complete computer-controlled alignment, and the innovative Microsource ${ }^{\circledast} \mathrm{x}$-ray generator for high-intensity XRD in sub-300 $\mu \mathrm{m}$ areas.

\section{Bicron Crystal Products \#805 \\ 750 South 32nd Street \\ Washougal, WA 98671 \\ Tel: 360-835-9815 \\ Fax: $360-835-9848$ \\ Scotch Plains, NJ 07076 \\ Tel: 908-233-7240 \\ Fax: 908-233-1354 \\ E-mail: blake4xray@ worldnet.att.net}

E-mail: cheikkinen@bicron.com www.bicron.com

Crystal Products, located in the Pacific Northwest, offers

Czochralski-grown sapphire substrates for blue LED and laser diodes, superconductors, and SOI, radiation-hardened, IC devices. Sizes are 2 -in. and 3-in. diameter C-plane and 2-in. to 6-in. diameter R-plane wafers. See our Sapphire Research Kits containing substrates oriented to $A, R$ and $C$ axes.

\section{Bio-Rad, Spectroscopy Division \#322 \\ 237 Putnam Avenue}

Cambridge, MA 02139

Tel: $617-868-4330$

Fax: 617-868-4026

E-mail: sales.digilab@biorad.com www.biorad.com

Bio-Rad, Spectroscopy Division will be exhibiting their line of FT-IR spectrometers including the latest in fast infrared imaging technology.

This includes micro-imaging, macroimaging and surface imaging using attenuated total reflectance (ATR).

Also on display will be latest in surface and thin film infrared spectroscopy systems which include grazing angle, IRRAS and micrograzing angle.

\section{Bioanalytical Systems, Inc. (BAS) \#623}

2701 Kent Avenue

West Lafayette, IN 47906-1382

Tel: 800-845-4246

Fax: 765-497-1102

E-mail: echem@bioanalytical.com www.bioanalytical.com

BAS manufactures and distributes a comprehensive line of electrochemical equipment, including potentiostats, galvanostats, impedance analyzers, and electrodes. BAS will be exhibiting the BAS $100 \mathrm{~B} / \mathrm{W}$ Electrochemical Workstation, the RDE-1 Rotating Disk Electrode, the BAS-Zahner IM6 Impedance Analyzer, and software for simulation of cyclic voltammetry $\left(\right.$ DigiSim $^{\circledR}$ ).
Blake Industries, Inc. \#911, $\underline{913}$

660 Jerusalem Road

Blake Industries will be exhibiting Huber rotary tables, translation stages, goniometer heads, $X-Y$ slits for synchrotron and rotating anode experiments. Blake monochromators, thin-film cameras, and Laue equipment will also be displayed.

\section{BOC Edwards \#610}

301 Ballardvale Street

Wilmington, MA 01887

Tel: $800-848-9800$

Fax: 978-658-7969

www.bocedwards.com

$B O C$ Edwards manufactures and services a complete line of high quality vacuum components and systems. Products include drypumps, rotary vane pumps, turbomolecular pumps, vacuum instrumentation, leak detectors, thin film coating systems, chillers, exhaust management systems and a wide range of vacuum accessories. Our BOC Edwards Vacuum Training Center offers a variety of courses ranging from general vacuum practices to specific product reviews. Our Applications Engineering team offers innovative solutions to optimize your vacuum system and 24 hour product support is available. Contact us at 1-800-848-9800 or www.bocedwards.com.

\section{Bruker AXS. Inc. \#505, 507}

6300 Enterprise Lane

Madison, WI 53719

Tel: $608-276-3000$

Toll Free: 800-234-XRAY

Fax: 608-276-3006

E-mail: info@bruker-axs.com

www.bruker-axs.com

Bruker specializes in $\mathrm{x}$-ray diffraction and fluorescence instrumentation, including configurations for phase identification, wafer analysis, thin film analysis, quantitative analysis, and single-crystal molecular structure determination.

Specialized equipment and software developments include high-resolution optics for analyzing epitaxial materials, two-dimensional detectors for texture and stress analysis, small angle scattering and microdiffraction, and advanced optics to increase $x$-ray flux.
Buehler, Ltd. \#724

41 Waukegan Road Lake Bluff, IL 60044

Tel: $847-295-6500$

Fax: 847-295-7929

www.buehlerltd.com

Buehler will be displaying the all new MPC 3000 Integrated Circuit Back-side Grinding System. This system is designed to accurately remove a pre-specified amount of material from a microelectronic sample without the need for operator intervention. The MPC 3000 is designed for precision ( \pm 2 micron) back-side grinding of semiconductor packages. A custom designed vacuum mounting system gives 5-micron parallelism across the chip.

\section{Burleigh Instruments, Inc. \#508}

P.O. Box E

7647 Main Street

Burleigh Park

Fishers, NY 14453-0755

Tel: 716-924-9355

Fax: 716-924-9072

E-mail: info@burleigh.com www.burleigh.com

Burleigh Instruments designs and manufactures precision surface imaging and measurement products for use in industrial and academic research applications and for quality control. Visit Booth No. 508 to see the company's full line of scanning probe microscopes and optical profilers including VISTA ${ }^{T M}$ and

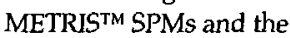
HORIZON ${ }^{\mathrm{TM}}$ non-contact optical profilometer.

\section{Caburn-International, Inc. \#1106} 20360 West Rue Crevier Unit \#612

Canyon Country, CA 91351

Tel: 661-298-3086

Fax: 661-298-4775

E-mail: alecmike@aol.com www.caburn-kohzu.com Caburn-International, Inc. is proud to introduce Kohzu Seiki of Japan. For the first time in the U.S., Kohzu's range of superb equality air-side precision stages and goniometers are now available on short delivery. Visit us at Booth No. 1106 to view a representative sample of these high-quality movement devices from the simplest manual $x$-y stage to motorized goniometer cradles and circular tables. Pick up a free copy of the new CabumKohzu catalog, which details hundreds of standard components with full specifications. 
Cambridge University Press \#824 40 West 20th Street New York, NY 10011-4211

Tel: $212-924-3900$

Fax: 212-691-3239

E-mail: marketing@cup.org www.cup.org

Stop by the Cambridge University Press booth to receive your $20 \%$ discount on Polymers at Surfaces and Interfaces by Richard A.L. Jones and Randal W. Richards, Fractography: Observing, Measuring and Interpreting Fracture Surface Topography by Derek Hull, The Nature of Mathematical Modeling by Neil Gershenfeld, and other fine titles. Science editor Simon Capelin will be available to discuss possible new book projects at the booth throughout the conference.

\section{- Cameca Instruments, Inc.} $\# 104$

204 Spring Hill Road

Trumbull, CT 06611-1356

Tel: 203-459-0623

Fax: 203-261-5506

E-mail: sales@cameca.com www.cameca.fr

Cameca Instruments will be highlighting their "NEW" SC ULTRA, SIMS for the most flexible support of wafer fabrication as well as its analytical instrument product line at this year's MRS Fall Exhibit. Please stop by the Cameca Booth No. 104 to learn more about the SC ULTRA, SIMS and the following products:

- IMS Wf, in-line wafer tool

- NanoSims 50, the SIMS with the highest lateral resolution and sensitivity

- IMS 6f, workhorse of semiconductor and geochemical research

- IMS 1270, high-performance analyzer for geochronology and geochemistry

- TOF SIMS IV and 300

- Cameca's SX100 EPMA, proving once again that Cameca is the innovator in X-ray microanalysis

\section{- Capovani Brothers Inc. \#221} 704 Corporation Park Scotia, NY 12302

Tel: 518-346-8347

Fax: 518-381-9578

E-mail: cbi@capovani.com www.capovani.com

Capovani Brothers Inc. is in the business of buying and selling equipment for science and industry. We offer a wide variety of equipment including but not limited to microscopes of all types, SEMs, lasers, optics, optical tables, breadboards, semiconductor process and fabrication equipment, thin film deposition and inspection, high vacuum, leak detection, ovens, furnaces, thermal shock, and environmental chambers, electronic test, mechanical test, including tensile, compression, vibration, shock, and much more. Capovani Brothers Inc. has been in business for the past ten years and takes pride in the service we provide to industry. All items are sold with a guarantee, and the satisfaction of our customers is our first priority.

\section{CERAC, Inc. \#202}

P.O. Box 1178

Milwaukee, WI 53201-1178

Tel: $414-289-9800$

Fax: 414-289-9805

E-mail: marketing@cerac.com www.cerac.com

CERAC manufactures an unparalleled selection of specialty inorganic chemicals, evaporation materials and sputtering targets. We are a leading supplier to industries such as optics and ophthalmics, semiconductor, disk drive, aerospace and more. Request a copy of the new 1999 CERAC full line catalog or browse the on-line version at www.cerac.com.

\section{Ceramaseal \#418}

P.O. Box 260

1033 Route 20

New Lebanon, NY 12125

Tel: 518-794-7800

Fax: $518-794-8080$

E-mail: info@ceramaseal.com www.ceramaseal.com

Ceramaseal offers a full range of standard ultra-high vacuum feedthroughs, connectors, thermocouples, cables, viewports and related hardware. New products include baseplate and crystal sensors line, glass-ceramic “ $\mathrm{D}$ " series, $50 \mathrm{ohm}$ SMA connectors, and high-density circular connectors.

\section{Chemat Technology, Inc. \#801}

9036 Winnetka Avenue

Northridge, CA 91324

Tel: 818-727-9786

Fax: 818-727-9477

E-mail: chemat@aol.com www.chemat.com

Chemat Technology, Inc. is the leading resource for total sol-gel processing. With centers worldwide, services offered include research and development, manufacture and distribution of metalorganic precursors for CVD and sol-gel, and the design and construction of thin film coating equipment. Standard and customized equipment range from lowcost spincoaters to sophisticated dipcoating systems. Chemicals are available in research and bulk quantities. Chemat's distinguishing feature is the ability to satisfy unique individual requirements.

\section{ChemIcon Inc. \#103}

7301 Penn Avenue

Pittsburgh, PA 15208

Tel: 412-241-7335

Fax: 412-241-7311

E-mail: chemicon@ chemimage.com

www.chemimage.com

ChemIcon Inc. is an innovative manufacturer of high performance materials characterization instruments. ChemIcon offers a broad range of instrumentation and chemical imaging services. ChemIcon manufactures the Falcon ${ }^{\mathrm{TM}}$ Raman Chemical Imaging Microscope that provides two-dimensional molecular images detailing materials morphology composition and structure.

Chemical imaging technology has successfully been applied by ChemIcon in many application market segments including polymers and coatings, semiconductors and pharmaceuticals.

Clemex Technologies, Inc. \#802 800 Guimond

Longueuil, Quebec J4G 1T5

CANADA

Tel: 450-651-6573

Fax: 450-651-9304

E-mail: info@dlemex.com www.clemex.com

Clemex Technologies will be exhibiting its CLEMEX IMPAK image analysis system and CLEMEX R'Kive Explorer archiving database. The CLEMEX IMPAK system is an affordable system that combines "best-of-breed" hardware components with Clemex Vision-the industry leading image analysis software solution. Used by quality control and research labs, the CLEMEX IMPAK system allows users to rapidly quantify images with minimal training. CLEMEX $\mathrm{R}^{\prime}$ Kive is a revolutionary image archiving application, integrated within MS Explorer

\section{Commonwealth Scientific \#213}

A Division of CVC, Inc.

500 Pendleton Street

Alexandria, VA 22314

Tel: 703-548-0800

Fax: 703-548-3138

E-mail: cscionbeam.com

www.ionbeam.com

Commonwealth Scientific, a division of CVC, Inc., offers a complete line of ion beam sources and integrated systems for ion beam etching and deposition, PVD, CVD, and DLC processes. Our products are successfully employed in numerous vacuum process applications, including magnetic, electro-optical, optical, superconductor, diamondlike carbon, and semiconductor.

- Gree Research, Inc. \#1203 4600 Silicon Drive

Durham, NC 27703

Tel: 919-313-5300

Fax: 919-313-5451

www.cree.com

Cree manufactures $4 \mathrm{H}-\mathrm{SiC}$ and $6 \mathrm{H}-\mathrm{SiC}$ substrates and epitaxy, semiinsulating $4 \mathrm{H}-\mathrm{SiC}$ substrates, high intensity blue LEDs and $\mathrm{SiC}$ UV photodiodes. $\mathrm{SiC}$ is an exceptional material for nitride deposition and the fabrication of semiconductor devices for high temperature, high power, high frequency power and optoelectronic applications. Custom device/design services available.

\section{Cressington Scientific Instruments \#211}

508 Thomson Park Drive Cranberry Twp., PA 16066-6425

Tel: 724-772-0220

Fax: 724-772-0219

E-mail: info@cressington.com www.cressington.com

Cressington will exhibit its newest benchtop vacuum coater, the 308 . Designed as a true multipurpose coater, the 308 can be configured for a wide variety of applications, from EM sample prep to thin film R\&D research. A 13 inch diameter baseplate allows for standard 12 inch bell jars or custom metal chambers to be used. Deposition methods include sputtering, thermal and electron beam evaporation. High vacuum pumps connect to an ISO 100 flange maximizing pump choice. 


\section{CRI, Inc. \#222}

80 Ashford Street

Boston, MA 02134

Tel: $617-787-5700$

Fax: 617-787-4488

E-mail: cri@cri-inc.com

www.cri-inc.com

CRI announces a revolutionary new imaging system, StressView ${ }^{\text {TM }}$. This system enables $Q C$ professionals to see and measure residual stress in many materials. Developed for the glass and semiconductor industries, StressView is a nondestructive test for microscopic and large-scale defect detection. Based on a patented imaging technique, StressView has an easy-to-use software and optics package that is suitable for both macro and microscopic test setups. CRI can customize the software to interface with process control software for fast production feedback.

\section{CRYO Industries of America, Inc. \#611}

11124 S. Willow Street

Manchester, NH 03103

Tel: 603-621-9957

Fax: 603-621-9960

E-mail: cryo@cryoindustries.com www.cryoindustries.com

'Performance by Design' cryogenic systems, traditional liquid helium/nitrogen systems and the latest cryogen-free refrigerator systems. We have it all! Come see what's new-14 $\mathrm{T}$ superconducting magnet, $1.5 \mathrm{~K}$ optical cryostat, A.C. susceptibility-all cryogen free, plus, economical $5.5 \mathrm{~K}$ refrigerator, crystallography CRYO cooler, microscopy cryostats and more.

\section{Cryogenic Control Systems, Inc. $\# 1208$}

P.O. Box 7012

Rancho Santa Fe, CA 92067

Tel: 858-756-3900

Fax: 858-759-3515

E-mail: sales@cryocon.com www.cryocon.com

Cryogenic Control Systems, based in Rancho Santa $\mathrm{Fe}, \mathrm{CA}$, is a manufacturer of precision cryogenic electronic instrumentation for both laboratory and industrial process control applications. We will be featuring the new Cryo-con Model $62 \mathrm{AC}$ Bridge-based autotuning cryogenic temperature controller as the latest addition to our line of temperature monitor and control products.
Cryomech, Inc. \#803

113 Falso Drive

Syracuse, NY 13211

Tel: 315-455-2555

Fax: 315-455-2544

E-mail: specs@cryomech.com

www.cryomech.com

NEW FROM CRYOMECH: A $4.2 \mathrm{~K}$

Pulse Tube Cryorefrigerator with

0.500 watts at $4.2 \mathrm{~K}$. Cryomech also manufactures standard laboratory cryostats, Gifford-McMahon cycle cryorefrigerators and liquid nitrogen plants. Customized cryostats for the unique experiment are available.

DCA Instruments, Inc. \#909

1 Hilltop Lane

White Plains, NY 10607-1709

Tel: 914-421-1969

Fax: 914-946-6766

E-mail: dcausa@att.net www.dca.co.uk

DCA Instruments specializes in the design and manufacture of highquality UHV deposition systems, offering standard systems for the following deposition techniques: III-V, II-VI, CMT-MBE, metal MBE, UHV sputtering, UHV laser ablation, and UHV CVD. DCA

Instruments also offers a wide range of MBE components which are retrofittable to the majority of existing systems. Components include effusion cells, soft-action magnetically driven linear shutters, a 'zerowobble' substrate manipulator and a self-regulating mercury source.

\section{Del Electronics, Power Conversion Products \#1116-1120}

One Commerce Park

Valhalla, NY 10595

Tel: $914-686-3600$

Fax: 914-686-2870

E-mail: ewilliams@delpower.com www.delpower.com

Del Power Conversion Group is a world leader in the design and manufacture of high voltage power supplies, transformers, noise suppression filters and high voltage capacitors. Our family of companies (Del Electronics, Bertan High Voltage and RFI Corp.) together comprises 140,000 sq. ft. and over 40 years experience in producing high voltage sub-systems for analytical, medical, industrial, scientific and defense applications. Virtually every major OEM, national lab and university uses a power supply, transformer or filter made by a division of Del.

From off-the-shelf rack instruments for everyday lab use, to custom modules and specialized systems for analytical XRD/XRF, CT imaging, semiconductor processing, and fundamental research, Del Power Conversion Group offers the knowledge, innovation and application support to meet all of your high voltage requirements.

Denton Vacuum LLC \#910, 912

1259 North Church Street

Moorestown, NJ 08057

Tel: 609-439-9100

Fax: 609-439-9111

E-mail: info@dentonvacuum.com www.dentonvacuum.com

Denton Vacuum will be exhibiting the Discovery ${ }^{\circledR}-18$ Sputtering System with the new Process Pro operating software. This system provides cutting edge technology in a system that is suitable for advanced research and pilot production. It is capable of multi-source deposition using normal DC, pulsed DC or solid-state RF power supplies. The system, operating in the confocal mode with 3 inch targets, can provide a deposition uniformity of better than $\pm 5 \%$ over a diameter of 6 inches.

\section{- Digital Instruments, Veeco} Metrology Group \#1010, 1012 112 Robin Hill Road

Santa Barbara, CA 93117

Tel: 805-967-1400

Fax: 805-967-7717

E-mail: info@di.com www.di.com

Digital Instruments, Veeco Metrology Group, offers a full spectrum of surface metrology systems. Our complete line of NanoScope ${ }^{E}$ SPMs includes the MultiMode ${ }^{\mathrm{TM}}$ SPM, the world's highest resolution SPM; the Dimension ${ }^{\mathrm{TM}}$ SPMs, offering the complete range of AFM and STM techniques for small or large samples; and the BioScope ${ }^{\mathrm{TM}}$ AFM, which combines optical and AFM techniques specifically for the biological sciences. We also offer a full range of Dektak ${ }^{(B)}$ stylus-based surface profiler systems for step height thin film measurement and surface roughness applications. Finally, the revolutionary Dimension Vx Atomic Force Profilers combine the cuttingedge technologies of AFMs and surface profilers to offer a long scan metrology tool with atomic force resolution.
Duniway Stockroom Corp. \#114

1305 Space Park Way

Mountain View, CA 94043-1336

Tel: $650-969-8811$

Toll Free: 800-446-8811

Fax: 650-965-0764

E-mail: info@duniway.com

www.duniway.com

Specializes in vacuum equipment and supplies: Ion pumps and controls; components (flanges, gaskets, bolts, nuts); vacuum gauges and controls from Terranova; mechanical pumps and rebuild kits; supplies (oils, greases, hoses, bell jars); and diffusion pumps and leak detectors. We offer rebuilding services and a large collection of reconditioned equipment. Free catalog.

\section{Eagle-Picher Technologies, LLC \#308}

Electro-Optic Materials

P.O. Box 737

Highway 69A

Quapaw, OK 66781

Tel: 918-673-1650

Fax: 918-673-2121

E-mail: epi-eom@mmind.net The "EOM" Department of EaglePicher Industries is a manufacturer of ultra high purity gallium metal, gallium trichloride, gallium sesquioxide, germanium tetrachloride, germanium dioxide, intrinsic germanium metal, germanium substrates, germanium, and silicon infrared optical materials. EaglePicher also purchases scrap gallium and germanium, in many forms, for recycling.

\section{- EDAX InC. \#817}

91 McKee Drive

Mahwah, NJ 07430

Tel: 201-529-4880

Fax: 201-529-3156

E-mail: info@edax.com

www.edax.com

EDAX Inc., established in 1962, is a leading innovator in the design and manufacture of energy dispersive $x$-ray analysis systems. On an international basis, EDAX supplies the microanalytical and $x$-ray spectrometry markets with PC-based systems for qualitative and quantitative elemental analysis. EDAX offers a full range of analytical systems including: the Phoenix which features the most advanced energy-dispersive $x$-ray analyzer system; the Eagle series featuring elemental analysis utilizing sophisticated capillary optics; and the Falcon which offers automatic peak identification and 
deconvolution with the various data reduction routines for quantification. Grain orientation and phase identification is carried out with the TSL product line using electron backscatter diffraction. Grain mapping and grain size analyses combined with automatic spot pattern indexing in the TEM for nanocrystalline thin films are also provided by TSL.

EG\&G Instruments, Inc. \#310

$801 \mathrm{~S}$. Illinois Avenue

Oak Ridge, TN 37830

Tel: 423-483-2121

Toll Free: 800-366-2741

Fax: 423-425-1334

E-mail: sales_echem@egginc.com www.eggpar.com

EG\&G Instruments, Inc. is a manufacturer and global distributor of instrumentation used for materials characterization, electrochemistry, corrosion, and impedance measurements. EG\&G Instruments, Inc. provides a full suite of potentiostats, galvanostats, analyzers, imaging equipment, cells and accessories. EG\&G Instruments, Inc. has a team of application experts to assist and support you with all your application needs.

\section{- Elsevier Science Inc. \#1023-1027 \\ 655 Avenue of the Americas New York, NY 10010-5107 \\ Tel: 212-633-3758 \\ Fax: 212-633-3112 \\ E-mail: usinfo-@elsevier.com www.elsevier.com}

Elsevier Science publishes a large number of journals and books in the field of materials science covering subjects from electronic materials, surface sciences, metals, materials chemistry and polymers. Our latest journal titles include Materials Science in Semiconductor Processing and Journal of Inorganic Materials. Visit our booth for sample copies of journals, $20 \%$ discount on books, copies of Materials Today magazine and online access to our Internet catalogue.

\section{- EMCORE Corporation \#709}

394 Elizabeth Avenue

Somerset, NJ 08873

Tel: 732-271-9090

Fax: 732-271-9686

E-mail: info@emcore.com

www.emcore.com

EMCORE Corporation is the leading

materials science company in the

field of compound semiconductors.
The company operates six divisions: EMCORE Research \& Application Laboratory (E.R.A.), TurboDisc Systems, EMCORE Electronic Materials ( $\left.\mathrm{E}^{2} \mathrm{M}\right)$, EMCORE Electronic Devices ( $E^{2} \mathrm{M}$ ), PhotoVoltaics, and MODE. These divisions cover the spectrum from basic R\&D on materials and production tools, to the design and manufacture of discrete devices. Each division provides the leading technology in its market. The core of the company is its in-depth materials science process expertise, which provides value-added service for its customers and each of its operating divisions. EMCORE is recognized throughout the world for the complete support provided to its customers, including full technical support for processes and systems. EMCORE provides continuing support from the early stages of design and installation through training and field service. EMCORE views its customers as its most valuable assets and is committed to their success.

\section{EOS-EyeOnScience \#1206}

913A Cloister Road

Wilmington, DE 19809

Tel: 302-793-0321 or 908-359-9825

Fax: 360-397-1364

E-mail: jigyasa@aol.com members.aol.com/jigyasa EOS, a division of Jigyasa, Inc., is a startup company developing multimedia-based informal science education software. Our products aim to present fundamental concepts and the scientific process underlying observed phenomena. Our product line, "Eye on Materials: An Interactive Multimedia Exposition," is designed to expose frontline issues in materials science with a view to attract undergraduate students towards research. At our exhibit, we will demonstrate a package on carbon that illustrates interesting structure-property interactions in carbon allotropes along with an overview of carbon as a material of current research. This endeavor is funded by a grant from the National Science Foundation. We are also developing a line of products based on allegorical science stories for children K-12.
- EPI MBE Products Group \#705

4900 Constellation Drive

St. Paul, MN 55127

Tel: $651-482-0800$

Fax: $651-482-0600$

E-mail: info@epimbe.com

www.epimbe.com

EPI leads the MBE industry with its innovative designs. Many of the world's leading research and production facilities are utilizing EPI's patented effusion cell technology to enhance the performance of their MBE systems. With over 10 years experience, EPI has pioneered the development of material-specific effusion cells and systems. Contact EPI for more information.

Epichem Inc. \#208

4905 Tilghman Street, Suite 240

Allentown, PA 18104

Tel: 610-706-0606

Fax: 610-706-0888

E-mail: muhrgt@epichem.com www.epichem.com

Epichem is the world's leading supplier of high purity metalorganics to the compound semiconductor industry. We offer over 50 products including volatile precursors of aluminum, gallium, indium, magnesium, iron, nitrogen, carbon, zinc, antimony, phosphorus, and arsenic. Epichem's proprietary adduct purification and reduced oxygen technology allow you to choose from a variety of grades-EpiPure, Adduct, and Electronic that best suit your application. Visit Epichem's booth to find out why Solution $\mathrm{TMI}^{\mathrm{TM}}$ has become the precursor of choice in III-V production environments.

\section{- Epion Corporation \#423 \\ 37 Manning Road \\ Billerica, MA 01821 \\ Tel: 978-670-1910 \\ Fax: 978-670-9119 \\ E-mail: sales@epion.com www.epion.com}

Epion Corporation is a supplier of ion and laser beam equipment for surface processing and deposition of thin films. The company has established unique expertise in emerging new technology for surface smoothing and atomic scale processing of surfaces by gas cluster ion beams and for deposition of thin film coatings by pulsed laser deposition. Services include ion implantation and diamondlike carbon coatings.
ESCETE Single Crystal
Technology 8.V. \#906

P.O. Box 3896

Ir. Schiffstraat

Enschede NL-7500 RD

THE NETHERLANDS

Tel: 31-53-4356146

Fax: 31-53-4352134

E-mail: escete@escete.com

www.escete.com

U.S. Agent: First Reaction

Tel: 603-929-3583

Fax: 603-929-5023

E-mail: firstrxn(10 aol.com

ESCETE Single Crystal Technology B.V. is a producer of high-quality oxide single crystal substrates, with a leading position in manufacturing HTSC-substrates, blue LED/laser sapphire substrates, optical isolators, laser rods, and other components for the electrical and photonic industry. ESCETE is also involved in research projects to develop future materials and devices in national and international projects.

- ESM Soltware \#727

2234 Wade Court

Hamilton, $\mathrm{OH} 45013$

Tel: 513-738-4773

Fax: 216-274-9026

E-mail: info@esm-software.com www.esm-software.com

ESM Software will demonstrate its materials science software collection including the new version of the TAPP materials properties database, an updated NIST Crystal Data collection, new polymer modeling software, and updates of software for crystallography, thermochemistry, phase diagrams, kinetics, thin films, and materials properties.

- Evans Analytical Group \#809

104 Windsor Center, Suite 101

East Windsor, NJ 08520

Tel: $609-371-4800$

Fax: 609-371-5666

E-mail: staff@evanseast.com

www.evanseast.com

The Evans Analytical Group specializes in materials characterization, contamination identification, failure analysis, quality control, surface, thin film, and trace element characterization. We apply our experience in high technology materials and state-of-the-art analytical techniques, such as dynamic SIMS (magnetic and quadrupole), TOF-SIMS, XPS, AES, SEM/EDS, AFM, FTIR, Raman, and GC/MS to solve customer problems quickly and cost 
effectively. The Evans Analytical Group consists of four separate labs across the United States and Europe including Charles Evans \& Associates in Redwood City, California; Evans East in East Windsor, New Jersey; Evans Texas in Round Rock, Texas and Evans Europe in the United Kingdom.

EXAKT Technologies, inc. \#323 7416 N. Broadway Ext., Suite E Oklahoma City, OK 73116-9066 Tel: 405-848-5800

Toll Free: $800-866-7172$

Fax: 405-848-7701

E-mail: linda.durbin@ exaktusa.com

EXAKT Technologies, Inc. provides precision equipment designed for use in the materials development/ $R \& D$ lab. Our equipment includes cutting machines specifically engineered to prepare specimens for evaluation of interfaces between materials; grinding devices that prepare multiple material samples with less than 0.5 micron deviation between material surfaces; and three roll mills for the preparation of difficult to process suspensions, pastes, inks or films for electronics, ceramics and other applications.

\section{- FEI Company/Philips Electron Optics \#700, 702 \\ 7451 NW Evergreen Parkway Hillsboro, OR 97124-5830 \\ Tel: $503-640-7500$ \\ Fax: 503-844-2615 \\ E-mail: semisales@feico.com www.feic.com}

FEI offers the broadest range of charged particle optics solutions available from a single source: Philips SEMs, TEMs and ESEMs, and FEI FIB, Wafer SEM and DualBeam FIB/SEM workstations. Our solutions serve a broad range of materials research applications: from general materials analysis with SEM, to high magnification imaging and analysis of dynamic, hydrated or heated specimens using ESEM; from high resolution, atomic-level TEM evaluation of structures and interfaces, to FIB-based failure analysis and defect classification on integrated circuits. All FEI instruments are designed for easy integration of additional analytical hardware, and operate under Windows NT 4.0, making them familiar and easy-to-use for all skill levels.
- Fischione Instruments $\# 900,902$

9003 Corporate Circle

Export, PA 15632

Tel: 724-325-5444

Fax: 724-325-5443

E-mail: info@fischione.com

www.fischione.com

Fischione Instruments manufactures a full line of instrumentation for electron microscopy. The family of specimen preparation instruments includes the twin-jet electropolisher, the specimen punch, the dimpling grinder, the specimen grinder, the ultrasonic disk cutter, and the lowangle milling and polishing (LAMP) ion mill. This line also includes the plasma cleaner, an instrument for preventing and eliminating carbonaceous contamination in TEM, SEM, and surface science applications. The TEM specimen holders include single tilt $-360^{\circ}$ rotate holder, the single tilt holder for fine tip specimens, and the analytical double tilt holder. Cryogenic TEM specimen holders include the single tilt analytical cryo holder, the TEM cryotransfer system, and the TEM anti-contaminator. Imaging instruments include the high angle annular dark field (HAADF) STEM detector capable of single electron detection. In North America, Fischione Instruments markets the chemical microscope, a bench-top imaging SIMS system manufactured by Millbrook Instruments.

\section{FRT of America \#519}

121R North Plains Industrial Road Wallingford, CT 06492

Fax: 011-49-2204-842431

E-mail: info@FRTofAmerica.com www.FRTofAmerica.com

Products include surface analysis instruments, MicroGlider ${ }^{(8)}$

MicroProf ${ }^{\circledR}$ and evaluation and control software (SPM [Mark III], LEED, AES). Services include surface analysis (damage analysis, quality assurance, processing optimization, development); in-line control (manufacture and integration); consultancy work (surfaces, new materials, new technology); and applied basic research. In addition, special services include scanning probe microscopy; examining nano hardness; and project work and studies.
Fujikin of America, Inc. \#622 2028 E. Ben White Blvd. Suite 320

Austin, TX 78741

Tel: 512-912-9095

Fax: 512-912-8095

E-mail: sales@fujikin.com www.fujikin.com

Fujikin is the world's leading manufacturer of valves and fittings for UHP applications. With surface finishes as low as $2 \mu$ in. $R a$, very low internal volume and extremely low particle generation, our conventional and surface mount products can take you to $300 \mathrm{~mm}, 180 \mathrm{~nm}$ and beyond. Contact us about our UHP steam generator and other cuttingedge products.

Genus, Inc. \#720

1139 Karlstad Drive

Sunnyvale, CA 94089

Tel: 408-747-7120

Fax: 408-747-7199

E-mail: pr@genus.com

www.genus.com

Genus, Inc. provides atomic layer deposition (ALD) technology that provides a strategic pathway to ultra-thin films. ALD bridges the gap for ultra-thin film requirements from now to beyond the horizon (2014) of the International Technology Roadmap for Semiconductors (TTRS). Genus is demonstrating films and systems in 2000 for advanced $R \& D$ environments. Initially, films will include aluminum and tantalum oxide as dielectrics, and titanium, tantalum and tungsten nitride as barriers, but the system is multipurpose capable. For more information, visit Genus' web site at www.genus.com.

\section{GFS Chemicals, Inc. \#522}

P.O. Box 245

Powell, OH 43065-0245

Tel: 740-881-5501

Toll Free: 800-858-9682

Fax: 740-881-5989

E-mail: gfschem@ gfschemicals.com

www.gfschemicals.com

Custom capabilities in both organic and inorganic specialties reflect the value GFS Chemicals offers to materials scientists. Organics include cholesteryl testers for liquid crystals, various phenylethynyl aromatics for luminescent materials; other acetylenic intermediates for coatings and sensors. Inorganics include high purity salts as precursors to optical materials; lithium perchlorate and other salts and electrolyte blends for battery research; anhydrous rare earth halides and other specialty dry salts for composite R\&D; metal complexes of phenanthrolines and other aromatics. Build your research program on our 70 years of experience manufacturing custom and specialty materials.

\section{- Goodfellow Corporation \#920}

800 Lancaster Avenue

Berwyn, PA 19312-1780

Toll Free: $800-821-2870$

Fax: $800-283-2020$

E-mail: info@goodfellow.com

www.goodfellow.com Goodfellow supplies small quantities of metals and materials for research and development. Our capabilities range from one off prototypes to small production quantities.

Gordon and Breach/Harwood Academic \#926

c/o International Publishers Distributor

P.O. Box 32160

Newark, NJ 07102

Tel: $973-643-7500$

Fax: 973-643-7676

E-mail: info@gbhap.com www.gbhap.com

Gordon and Breach/Harwood

Academic publishes books and journals of interest to scientists and engineers in condensed matter physics and materials science, including nanotechnology, optics and lasers, surface physics, nonlinear dynamics, and superconductivity.

\section{Hamamatsu Corporation \#806}

360 Foothill Road

Bridgewater, NJ 08807

Tel: 908-231-0960

Fax: 908-231-1218

www.hamamatsu.com

Hamamatsu Corporation is one of the world leaders in photo detector and light source manufacturing. Hamamatsu Corporation is introducing a new advanced detector for the near infrared region. The R5509-42/72 has a response range to $1.4 \mu \mathrm{m}$ or $1.7 \mu \mathrm{m}$. These detectors feature fast response time as well as single photon counting performance, allowing weak light detection in the near infrared region. Technical contact: Hamamatsu Corporation at 800-524-0504. 
- High Voliage Engineering Europa B.V. \#1017 P.O. Box 99

3800 AB Amersfoort THE NETHERLANDS

Tel: 31-33-4619741

Fax: 31-33-4615291

E-mail: info@highvolteng.com www.highvolteng.com

High Voltage Engineering, an engineering-oriented company, designs, manufactures, sells and markets custom-made, high-tech capital equipment for the world market.

Specializing in the development and manufacture of ion beam technologybased equipment, High Voltage Engineering is the largest and most diverse manufacturer of particle accelerator systems for the scientific, educational and industrial research communities. Major product lines include: Ion Accelerator Systems, Research Ion Implanters, Systems for Ion Beam Analysis, and various components such as $\mathrm{HV}$ power supplies, electron and ion accelerator tubes, ion sources, beamline components, beam monitoring equipment, etc.

Hinds Instruments, Inc. \#1110, 1112

3175 NW Aloclek Drive Suite 170

Hillsboro, OR 97124-7135

Tel: 503-690-2000

Fax: $503-690-3000$

E-mail: info@hindspem.com www.hindspem.com

Hinds Instruments manufactures PEM-90' ${ }^{\text {TM }}$ photoelastic modulators (PEMs) and Exicor ${ }^{\mathrm{TM}}$ birefringence measurement instrumentation. PEMs operate in the vacuum UV to mid-IR spectral regions at frequencies of 20 to $100 \mathrm{kHz}$. These devices provide polarization modulation for the following applications: Stokes polarimetry, Rheology, ellipsometry, spectroscopy and optical rotation. Exicor ${ }^{\mathrm{TM}}$ provides unprecedented sensitivity and repeatability in lowlevel birefringence measurement.

\section{Hitachi Scientific Instruments \#401 ISLE \\ Nissei Sangyo America, Ltd. 755 Ravendale Drive Mountain View, CA 94043 Tel: $415-969-1100$ Fax: 415-961-0368 E-mail: sidsales@nissei.com www.nissei.com}

The HD-2000 dedicated Scanning Transmission Electron Microscope (STEM) is a powerful, high- performance, easy-to-use research and inspection tool. The system operates on a familiar Windows 95 platform with operational ease-ofuse the same as a SEM, and is capable of resolving $2.35 \AA$ guaranteed. When coupled with Hitachi's Focused Ion Beam (Model FB$2000 \mathrm{~A}$ ), it gives the user a rapid TEM/STEM sample preparation system for failure analysis that provides pinpoint accuracy, cross-sectioning with quality results. Alternating between the FB-2000A and HD-2000 STEM, the user can return to precise areas of interest using the high voltage SEM/STEM image on the HD-2000 before returning to the FIB for further milling.

\section{- Huntington Mechanical Laboratories, Inc. \#1001} 1040 L'Avenida Street

Mountain View, CA 94043-1422 Tel: 650-964-3323

Fax: 650-964-6153

E-mail: vacman@huntvac.com www.huntvac.com

The industry's largest selection of vacuum valves, flanges, fittings, and feedthroughs is available when you need it at Huntington. Also available are a wide assortment of roughing components including flexible hoses, traps, thermocouple and ionization gauge tubes, sorption and jet roughing pumps. Standard, custom, or modified UHV positioning and motion devices can be provided to meet your special needs. Stainless steel custom chambers, tees, and crosses are supported by a quarter of a century of experience in vacuum chamber design and fabrication at Huntington.

\section{- Hysitron, Inc. \#517}

5251 West 73rd Street

Minneapolis, MN 55439

Tel: $612-835-6366$

Fax: 612-835-6166

E-mail: hysitron@hysitron.com www.hysitron.com

Hysitron, Inc. is an engineering firm specializing in the design and manufacture of force and displacement transducers. Known for its worldclass status TriboScope ${ }^{\circledR}$ with in situ imaging for mechanical properties at nanoscale, Hysitron will introduce the Tribolndenter ${ }^{\circledR}$ as the nanoindenter for the new millenium.
Implant Sciences Corporation \#820

107 Audubon Road, \#5

Wakefield, MA 01880

Tel: $781-246-0700$

Fax: 781-246-1167

E-mail: mail@implantsciences.com www.implantsciences.com

Implant Sciences Corporation offers fast, high quality ion implantation services for virtually any application. Over 60 species are available into any substrate material. In addition, substrate temperature can be controlled from $-150^{\circ} \mathrm{C}$ to $1000^{\circ} \mathrm{C}$. Profile Code ${ }^{\mathrm{TM}}$ software is also available for accurate ion implantation simulation.

\section{Industrial Science \& Technology Network, Inc. \#1205}

2101 Pennsylvania Avenue

York, PA 17404

Tel: 717-843-0300

Fax: 717-843-0705

E-mail: istn@blazenet.net

www.istn-thermal.com

ISTN offers innovative products in two major areas-thermal conductivity measurement and absorption of heavy metals from wastewater. Measurement of thermal conductivity on materials such as insulation and composite sheet is available both through service and instrument sales. Equipment that provides fast and accurate measurement on liquid samples is our newest product line. Our second area of expertise is in absorption of heavy metals from wastewater. We currently manufacture several different products with super absorbent properties that can be tailored to meet your remediation and recovery needs. Additionally, ISTN performs contract research in a variety of areas.

Inel, Inc. \#605

P.O. Box 147

Stratham, NH 03885

Tel: 603-778-9161

Fax: 603-778-9171

E-mail: inelinc@aol.com

www.valcofim.fr/inel

Manufacturers of diffractometer systems incorporating curved or linear position sensitive detectors.

Applications include texture analysis, powders, thin films, reflectometry, polymers, in situ, on-line, and dynamic studies. Representing
Cilas neutron guides and diffractometers and GMI beam line instrumentation such as rotary tables. Representing Diacell Products' high-pressure diamond cells.

\section{- Inorgtech Lid. \#904}

25 James Carter Road

Mildenhall, Suffolk IP28 7DE

UNITED KINGDOM

Tel: 44-1638-714423

Fax: 44-1638-718259

E-mail: sales@inorgtech.co.uk www.inorgtech.co.uk

Inorgtech manufactures chemical precursors for deposition of oxide and nitride thin films by MOCVD and CSD techniques in a range of application areas including

dielectrics, diffusion barriers, ferroelectrics, antireflection, transparent conductors, electrochromics, superconductors, thermal barriers and other emerging thin film technologies. The company operates an applied science laboratory for developing, characterizing and testing its products and has an active publication policy for disseminating technical information.

\section{INSACO, Inc. \#206}

P.O. Box 9006

1365 Canary Road

Quakertown, PA 18951

Tel: 215-536-3500

Fax: 215-536-7750

E-mail: sales@insaco.com

www.insaco.com

INSACO is a precision fabricator utilizing advanced ceramic materials including sapphire, ceramics from all producers, glass, quartz, and many others. We machine these materials to very precise dimensions and tolerances in a variety of shapes and configurations as required by our customers. We have no standard parts; everything is manufactured to specific customer requirements and we work from single prototypes through full production runs.

\section{Institute of Physics Publishing} $\# 825$

The Public Ledger Building

Suite 1035

$150 \mathrm{~S}$. Independence Mall West

Philadelphia, PA 19106

Tel: 215-627-0880

Fax: 215-627-0879

E-mail: info@ioppubusa.com www.iop.org

Institute of Physics Publishing, a not-for-profit scientific publisher, produces a variety of journals, books 
and magazines. At the 1999 MRS Fall Exhibit, IoP features Smart Materials and Structures, Modelling and Simulation in Materials Science and Engineering and High Performance Polymers. Stop by for a free sample copy of these and other IoP journals. We also offer a $20 \%$ discount on our books, which are now available online at bookmark.iop.org. Visit our website at www.iop.org.

\section{Institution of Electrica \\ 379 Thornall Street \\ Edison, NJ 08837 \\ Tel: 732-321-5575 \\ Fax: 732-321-5702 \\ www.iee.org.uk} Engineers/INSPEC \#1021

Stop by our booth to learn more about the EMIS Datareviews Series published by the Institution of Electrical Engineers (INSPEC division). The EMIS Series comprises over 20 books of tables, text and fig. ures on electronic materials, including the recently published Properties of Crystalline Silicon, edited by former MRS president Robert Hull. Also on display will be the full range of INSPEC and IEE products and services for scientific and technical researchers. Visit us online at www.iee.org.uk/publish/.

\section{Instruments S.A., Inc./ \\ Horiba Group/ \\ JY Emission Division \\ (See Jobin Yvon/HORIBA)}

\section{Instruments S.A., Inc./ \\ Horiba Group \#412}

Raman Division

3880 Park Avenue

Edison, NJ 08820

Tel: 732-494-8660

Fax: 732-549-2571

E-mail: raman@isainc.com www.isainc.com

ISA's state-of-the-art Raman and thin film products continue to provide analytical capabilities by integrating emerging technologies. The LabRam is a compact, benchtop microprobe with options for confocal imaging, macro-sampling, and remote probes, including a multipass gas probe. The $X Y$ provides similar functions but with higher spectral resolution. The UVISEL provides information on thickness, optical properties, composition, surface properties and morphology of thin films
- Insulator Seal, Inc. \#810

6460 Parkland Drive

Sarasota, FL 34243

Tel: 941-751-2880

Fax: 941-751-3841

E-mail: sales@isi-seal.com

www.isi-seal.com

ISI, the leader in ceramic-to-metal joining, serves vacuum science and industry worldwide. ISI's leadership in seal technology is maintained by a core of engineers, providing unique solutions to a continuously expanding market. Standard product lines include multi-pin, coaxial, thermocouple and power feedthroughs; also, breaks, viewports and custom design products.

\section{- Ion Tech, Inc. \#511, 513}

2330 East Prospect

Fort Collins, CO 80525

Tel: 970-221-1807

Fax: 970-493-1439

E-mail: info@iontechinc.com

www.iontechinc.com

Ion Tech, Inc. is the industry leader in the design and manufacture of ion beam systems and sources to meet any research or production requirement. Our product line features thin film deposition and etch systems, DC and filamentless RF ion beam sources in both linear and round configurations, cylindrical magnetrons and power supplies.

\section{Janis Research Company, Inc.} \#908

P.O. Box 696

Two Jewel Drive

Wilmington, MA 01887-0696

Tel: $978-657-8750$

Fax: 978-658-0349

E-mail: janis@janis.com

www.janis.com

Janis combines over 35 years of manufacturing experience with extensive engineering capabilities to provide cryogenic systems for all research applications. Janis offers closed-cycle refrigerators, $4 \mathrm{~K}$ refrigerators, continuous flow and variable temperature cryostats, superconducting magnet systems, detector cooling dewars, dilution refrigerators, Helium- 3 cryostats, and custom designs to meet any specific requirements.
- JCPDS-ICDD \#1004

12 Campus Blvd.

Newtown Square, PA 19073-3273

Tel: $610-325-9810$

Fax: 610-325-9823

E-mail: info@icdd.com

www.icdd.com

The International Centre for Diffraction Data maintains and distributes the Powder Diffraction database for use in materials characterization via $x$-ray analysis. The most recent version of the database, Release 99, comprises over 120,000 numeric diffraction patterns of crystalline phases on CD-ROM and in print. Specialized products such as computer software; minerals subfiles; metals and alloys subfiles; educational products; and the Advances in X-Ray Analysis on CD-ROM are also available.

\section{- JEOL USA, Inc. \#800}

11 Dearborn Road

Peabody, MA 01960

Tel: 978-535-5900

Fax: 978-536-2205

E-mail: eod@jeol.com

www.jeol.com

A $200 \mathrm{kV}$ computer-controlled FEG with better than $0.2 \mathrm{~nm}$ point resolution in STEM HAADF; a $4.0^{\circ} \mathrm{K}$ UHV STM; a UHV AFM/STM with non-contact, atomic resolution; a new ambient/environmental SPM with cold and hot stage; a new UHV scanning auger microprobe with TFEG gun; a new SEM with $1.5 \mathrm{~nm}$ resolution and a new, NT-based user interface; all the other high performance, reliable instruments in the JEOL product line. Ask for more information.

- J.I.P.ELEC \#317, 319

11 Chemin du Vieux Chêne F38240 Meylan

FRANCE

Tel: 33-476-040606

Fax: 33-476-048140

E-mail: jipelec@ipelec.com www.jipelec.com

J.I.P.ELEC supplies cold wall RTP and RTCVD reactors. Fast therma switching, vacuum and gas mixing capabilities are standard features. Equipment for RTCVD, LPCVD and MOCVD are available. Our product line includes JetFirst, a low-cost RTP processor; Inject, a liquid delivery system for MOCVD; TubeSTAR, a LPCVD tubular furnace; and SiC furnace, an induction furnace for silicon carbide anneling up to $2000^{\circ} \mathrm{C}$.
Jobin Yvon/HORIBA \#410

(previously Instruments S.A., Inc.) HORIBA Group//Y Emission)

3880 Park Avenue

Edison, NJ 08820

Tel: 732-494-8660

Toll Free: 800-533-5946

Fax: 732-494-8796

www.jyhoriba.com

Manufacturer of diffraction gratings and spectroscopic systems including spectrometers, imaging spectrographs, CCD detectors, spectrofluorometers, Raman microprobes, emission spectroscopy systems, OEM systems and optical subassemblies, semiconductor process control instrumentation, semiconductor end-point control systems, thin-film measurement systems, ellipsometry systems and forensics systems.

- Johnsen Ultravac \#1019 3470 Mainway Burlington, Ontario L7M 1A8 CANADA

Tel: 905-335-7022

Toll Free: 800-268-4980

Fax: 905-335-3506

E-mail: juvinfo@ultrahivac.com www.ultrahivac.com

Johnsen Ultravac manufactures a complete line of vacuum products for R\&D, production and light sources including six axis manipulators featuring maximum \pm 4.00 inch $X Y$ motion, heating/ cooling stages with $10 \mathrm{~K}$ to $1500 \mathrm{~K}$ temperature range, ultra-long stroke linear motion translators, UHV XYZ translators with 500 lbs. payload capacity, XYZ stages for in situ analysis, $5 \times 10^{-11}$ Torr UHV chambers, beam line components, monochromators and a wide range of vacuum systems for surface analysis, semiconductor, optoelectronics and coating. We specialize in unique, one-of-a-kind projects.

\section{Johnson Matthey Electronics \#307 \\ M/S 3-33 \\ 15128 E. Euclid Avenue Spokane, WA 99216 \\ Tel: 509-924-2200 \\ Fax: 509-252-8734 \\ www.jmei.com}

Johnson Matthey Electronics, a major supplier of single-crystal compound semiconductors used in infrared systems and optoelectronic devices, is a primary producer of high-quality sapphire products for semiconductor and optical applications. JME refines and fabricates 
high-purity metals used in singlecrystal semiconductors, die attach materials, sputtering targets, seal lids, and profiling thermocouples.

- k-Space Associates, Inc. \#719

555 S. Forest Avenue, Suite 4B Ann Arbor, MI 48104

Tel: 734-668-4644

Fax: 734-668-4663

E-mail: ksa@k-space.com www.k-space.com

$k$-Space specializes in thin-film characterization and high-performance scientific imaging products. Our kSA 300/400 systems set the standard for analytical RHEED. Our new kSA MOS (Multibeam Optical Sensor) system provides in situ, 2-dimensional thin-film stress and thickness characterization. For general vision-based experiments, nothing beats EyeSpy for performance, flexibility and affordability.

\section{Keithley Instruments, Inc. \#510 \\ 28775 Aurora Road \\ Solon, OH 44139 \\ Tel: $440-248-0400$ \\ Fax: 440-248-6168 \\ E-mail: product_info@ keithley.com \\ www.keithley.com}

Keithley will display its line of sensitive test instrumentation designed for materials research applications. Keithley has added to its family of electrometers with the new Model 6514 programmable electrometer. The Model 6514 is ideal for applications that demand fast, precise measurements of low currents or high resistances. Also highlighted will be the Model 65 high resistivity measurement package and the Model 2182 nanovoltmeter.

\section{- Kimball Physics, Inc. \#612 \\ 311 Kimball Hill Road \\ Wilton, NH 03086 \\ Tel: 888-KIM-PHYS (888-546-7497) \\ Fax: $603-878-3700$ \\ E-mail: info@kimphys.com www.kimphys.com \\ UHV Electron and Ion Sources/ \\ Systems: Beam energies $5 \mathrm{eV}$ to 100 $\mathrm{keV}$, high brightness sources, cath- odes, cathode cartridges, Faraday cups, phosphor screens. System Options: Energy sweeping, raster- ing, fast pulsing. UHV Components: Multi-CF fittings, miniature vacuum systems, $\mathrm{eV}$ parts. Applications: Surface}

physics, vacuum physics, charge neutralization, cathodoluminescence, phosphor testing, semiconductor processing, RHEED, ESD. Custom designs. Visit us at www.kimphys.com.

\section{- KLA-Tencor Corporation \#718}

160 Rio Robles

San Jose, CA 95134-1809

Tel: 408-875-3000

Fax: 408-875-4144

www.kla-tencor.com

KLA-Tencor is the world's leading manufacturer of yield management and process control systems for the semiconductor industry. KLA-

Tencor offers a broad range of products including automated systems for in-line defect monitoring on patterned and unpatterned wafers, reticle and photomask defect inspection, thin film and resistivity measurement, wafer overlay and $C D$ SEM metrology, flat panel display measurement, thin film head and disk inspection and metrology. Also provided are defect data analysis products and yield management consulting services which span the company's product lines.

\section{- Kluwer Academic/} Plenum Publishers \#922, 924

101 Philip Drive

Norwell, MA 02061

Tel: 781-871-6600

Fax: 781-871-6528

E-mail: kluwer@wkap.com www.wkap.nl

Kluwer Academic/Plenum Publishers, a leading publisher of scholarly, scientific and technical books and journals, invites you to visit our booth at MRS. Browse through our latest publications in materials science. A $20 \%$ discount is available on all books on display.

- Kratos Analytical, Inc. \#606

100 Red Schoolhouse Road

Building A

Chestnut Ridge, NY 10977

Tel: $914-426-6700$

Fax: 914-426-6192

E-mail: jd@kratos.com

www.kratos.com

Kratos proudly announces that it now offers a complete range of instrumentation (benchtop and ultra high performance models) for materials analysis. Techniques include XPS/ESCA, AES/SAM, UPS, ISS, SIMS, WDXRF, EDXRF and XRD These instruments perform fast, reliable analysis ranging from a material's surface chemistry to the total elemental composition.

- Kurt J. Lesker Company \#712 1515 Worthington Avenue Clairton, PA 15025-2700

Tel: 412-233-4200

Toll Free: 800-245-1656

Fax: 412-233-4275

E-mail: sales@lesker.com international@lesker.com www.lesker.com

Worldwide distribution of: linear and circular Torus ${ }^{\circledR}$ sputtering magnetrons; e-beam, thermal and epitaxy sources; targets and materials of all purities; custom UHV chambers; electrical, gas/liquid, motion feedthroughs; and the AccuQuad ${ }^{(B)}$ RGA. Also offering high vacuum and UHV sample manipulation and surface science components.

\section{Ladd Research Industries, Inc. \#520}

13 Dorset Lane

Williston, VT 05495

Tel: 802-878-6711

Fax: 802-878-8074

E-mail: sales@ladd.cc www.ladd.cc

Specialties include:

- Apertures-All electron microscopes. Platinum, molybdenum strips and discs $5 \mu \mathrm{m}$ and above.

- Microholes-Slits/holes, various metals and sizes. Applications include $x$-ray, gas flow, ion beam, E-beam, light flow and solder droplets

- Equipment-Vacuum evaporators, sputter coaters, ultra sonic cleaners, etc.

- Supplies-Tweezers, specimen mounts, standards, precision tools, chemicals, photographic supplies, etc.

\section{- Lake Shore Cryotronics, Inc.} $\# 512$

575 McCorkle Blvd.

Westerville, $\mathrm{OH}$ 43082-8888

Tel: 614-891-2243

Fax: 614-818-1600

E-mail: sales@lakeshore.com www.lakeshore.com

Integrated Hall effect and magnetoresistance semiconductor material characterization systems with Van der Pauw resistivity measurements; features QMSA, a new data-manipulation algorithm which simultaneously derives concentrations and mobilities for multiple distributions of electrons and holes in layered semiconductor device structures.
Also vibrating sample magnetometers, AC susceptometers/DC magnetometers, cryogenic platforms; high-level, Windows ${ }^{\mathrm{TM}}$-based instrument management software; new Model 340 dual loop temperature controller with multiple sensor inputs, cryogenic temperature sensors, gaussmeters, Hall generators, electromagnets, and four-quadrant power supplies.

Lambda Physik, Inc. \#616

3201 West Commercial Blvd.

Suite 110

Fort Lauderdale, FL 33309

Tel: 954-486-1500

Toll Free: 800-EXCIMER

Fax: 954-486-1501

E-mail: marketingusa@ lambdaphysik.com

www.lambdaphysik.com

Lambda Physik is the leading manufacturer of UV-lasers and produces excimer, dpssI Nd:YAG and tunable lasers for industry, microlithography $(248,193,157 \mathrm{~nm})$, medicine and science. The new $F_{2}$ lasers $(157 \mathrm{~nm})$ enable still higher precision in ablation and structuring, especially for tough materials such as silicon, fused silica and PTEE (Teflon). The laser spectrum also includes industrial excimer lasers for PLD and recrystallization of amorphous silicon.

\section{- LEO Electron Microscopy Inc. $\# 601,603$}

One Zeiss Drive

Thornwood, NY 10594

Tel: 914-747-7700

Fax: 914-681-7443

E-mail: MDelulio@ compuserve.com

www.leo-em.co.uk

LEO Electron Microscopy Inc. is pleased to announce the introduction of the LEO 1400 Series, a family of six high performance, conventional and variable pressure scanning electron microscopes. Our

Integrated Computer Environment, ICE, brings together all of the major control functions of the SEM. More than a digitally interfaced add-on $\mathrm{PC}$, ICE merges the hardware and software of the microscope so that every operating parameter is available for control or automation. LEO-32, the intuitive graphical user interface of the SEM, is the culmination of 13 years of software control experience. Full operating system compatibility with either Windows ${ }^{\oplus}$ 98 or Windows ${ }^{\circledR}$ NT is guaranteed, as is full Year $\mathbf{2 0 0 0}$ compliance. The 
new LEO VPSE detector provides a secondary electron image while operating in VP mode. Operated through mouse, keyboard or multifunctional control panel, the LEO 1400 Series provides ease of use to the novice or occasional operator while meeting the needs of the most challenging applications. All LEO Electron microscopes are equipped with clean, fast, turbo-molecular pumps as standard. This eliminates the possibility of sample contamination and reduced EDS detector performance.

\section{- Leybold Vacuum Products.} Inc. \#706

5700 Mellon Road

Export, PA 15632-8900

Tel: 724-327-5700

Fax: 724-733-1217

E-mail: info@leyboldvacuum.com www.leyboldvacuum.com

Leybold Vacuum is a full-line supplier of vacuum pumps and pumping systems, well suited for research applications. Our products range from mechanical and magnetic bearing turbomolecular pumps, rotary vane pumps to dry pumps, and pumping systems. The EcoDry L dry piston pump offers low cost-ofownership through less power consumption, no cooling water, nitrogen or oil needed, and less parts. Our turbo pumps feature state-ofthe-art rotor design for increased reliability and performance. Visit our online store at www.buyvacuum.com.

\section{Logitech Product Group \#200}

810 Shamon Drive

Westlake, $\mathrm{OH} 44145$

Tel: 440-871-0071

Fax: 440-871-8188

E-mail: info@logitech-us.com www.logitech-us.com

Logitech is a manufacturer of high precision sawing, lapping and polishing equipment. Research and small-scale production systems ane available for substrate backthinning and polishing GaAs, InP, sapphire, silicon and other semiconductor wafers, electro-optic crystals, ceramics, waveguides, laser rods and optical components. We also supply a full range of lapping and polishing consumables. For additional information call Keith Torrance at 800-321-5834.
MBRAUN, Inc. \#905

65 Parker Street, Unit 5

Newburyport, MA 01950

Tel: $978-462-1770$

Fax: 978-462-1862

E-mail: mbgloveboxes@msn.com www.mbraun.de

MBRAUN produces inert atmosphere glove boxes (UNIlab, Labmaster, MB150BGII, isolators, welding chambers) and a position sensitive detector for $\mathrm{x}$-ray diffraction. Glovebox operates at $<1 \mathrm{ppm}$ $\mathrm{H}_{2} \mathrm{O} / \mathrm{O}_{2}$ with $50 \mathrm{cfm}$ circulation, high capacity purifier. Simple PLC operation, solid state analyzers, freezers, ovens, microscope assembly, solvent removal, nitrogen removal. New Options: solvent purification, stand-alone solid state analyzers. PSD uses Windows software, four versions of measurement, up to 80 microns position resolution.

\section{- MDC Vacuum Products}

Corporation \#812

23842 Cabot Blvd.

Hayward, CA 94545

Tel: 510-265-3500

Fax: 510-887-0626

E-mail: sales@mdc-vacuum.com www.mdc-vacuum.com

Complete line of UHV components including: flanges and fittings, valves, roughing components, instrumentation, electrical feedthroughs, XYZ manipulators, rotary and linear feedthroughs, fastentry load-lock systems, all-metal sealed right angle valves and M.E.S.A. compatible rectangular gate valves. A complete line of electron beam evaporation sources in single-pocket and multi-pocket configuration with matching $6 \mathrm{kw}, 10$ $\mathrm{kw}$, and $15 \mathrm{kw}$ solid-state switching power supplies.

\section{- Micro Photonics, Inc. \#1016, 1018}

4972 Medical Center Circle P.O. Box 3129

Allentown, PA 18106-0129

Tel: 610-366-7103

Fax: 610-366-7105

E-mail: info@microphotonics.com www.microphotonics.com Micro Photonics supplies nanohardness testers, micro-scratch testers and tribometers for measuring thin film hardness, adhesion, and wear resistance; ellipsometers and reflectometers for measuring thin film thickness and optical properties; non-contact 2D and 3D profilometers for measuring surface topography; $\mathbf{x}$-ray microtomographs for measuring material microstructure; and $\mathrm{CCD}$ cameras for $\mathrm{x}$-ray imaging.

\section{Microcal Software, Inc. \#921}

One Roundhouse Plaza

Northampton, MA 01060

Tel: 800-969-7720

Fax: 413-586-9665

E-mail: info@microcal.com

www.microcal.com

Offering Origin, the "fastest path from data to presentation." These powerful data analysis tools include linear and nonlinear curve fitting, FFT, digital signal analysis, baseline and peak analysis, statistics and more. Create publication ready graphs in Origin or add your Origin graphs to your favorite presentation software.

\section{MKS Instruments, Inc. \#916, 918 \\ Six Shattuck Road \\ Andover, MA 01810 \\ Tel: 978-975-2350 \\ Fax: 978-975-0093 \\ E-mail: mks@mksinst.com \\ www.mksinst.com}

MKS Instruments, Inc. will feature several products across its entire product line oriented towards advanced materials research, such as low- and high-K dielectrics and copper manufacturing processes. These products represent the latest in measurement and control technology as well as in situ process diagnostics.

- MMR Technologies, Inc. \#1007

1400 N. Shoreline Blvd., Suite A-5

Mountain View, CA 94043-1346

Tel: 650-962-9620

Fax: 650-962-9647

E-mail: mmr@mmr.com www.mmr.com

MMR Technologies manufactures temperature controlled systems-cryogenic cooling systems and wide temperature range thermal stageswhich find application in materials research in electrical engineering, physics, biology and chemistry applications over the temperature range of $10 \mathrm{~K}$ to $730 \mathrm{~K}$. They are also used in the cooling of computer chips, electronic devices, laser diodes, and thermal imaging devices, and in the characterization of the performance and properties of such devices as a function of temperature.
Molecular Metrology, Inc. \#205

141 Bridge Road

Salisbury, MA 01952

Tel: 978-499-0899

Fax: 978-499-2917

E-mail: info@molmet.com

www.molmet.com

Molecular Metrology, Inc. designs and manufactures $x$-ray diffraction equipment, specializing in customized instruments for surface and small angle scattering. Our products include user-friendly instruments for SAXS, ultra-SAXS, rapid $x$-ray reflectivity, $x$-ray standing wave fluorescence, $x$-ray scattering from liquid surfaces, as well as $x$-ray focusing optics. We have developed an open platform design that allows integration of $x$-ray measurement tools into other processes for in situ studies and quality control.

\section{Molecular Simulations Inc. \#704 \\ 9685 Scranton Road \\ San Diego, CA 92121 \\ Tel: 858-458-9990 \\ Fax: 858-458-0136 \\ E-mail: byronk@msi.com \\ www.msicom}

Visit MSI to find out how computer modeling predicts properties, designs and characterizes new materials, and helps you to optimize processes. Applications include solid state materials, where researchers apply MSI's CASTEP and DMo13 codes to predict structure and properties with high accuracy, and polymeric and soft materials, where MSl's industry-leading simulation tools are now complemented with new capabilities to model the mesoscale.

Morton International, Inc. (see Rohm and Haas Company)

\section{MTI Corporation \#318}

5327 Jacuzzi Street, Unit 3G

Richmond, CA 94804

Tel: $510-525-3070$

Fax: 510-234-5235

E-mail: mtixpj@aol.com

www.mticrystal.com

Our primary products are high quality single crystals of oxides, compound semiconductors and advanced optical materials as well as our nanopowders that are produced by an innovative process of laser decomposition. We also market ultra-pure rare earth oxides and high purity alumina ceramics. Tailoring to customer's special requirements and very competitive pricing are our strengths. 
- MTS Systems Corporation \#301 ISLE

14000 Technology Drive

Eden Prairie, MN 55344-2290

Tel: $612-937-4000$

Fax: 612-937-4515

E-mail: info@mts.com

www.mts.com

MTS Systems Corporation designs, engineers and manufactures testing systems that characterize the mechanical properties of materials and structures. With the acquisition of Nano Instruments, Inc.--renamed the Nano Instruments Innovation Center-MTS provides nanometer and microNewton capabilities through Nano Indenter ${ }^{(1)}$ systems, in addition to microforce capabilities through the Tytron ${ }^{\mathrm{TM}} 250$ system, and low-force capabilities through electromechanical and servohydraulic systems.

Nano Instruments Innovation Center

1001 Larson Drive

Oak Ridge, TN 37830

Tel: 423-481-8451

Fax: 423-481-8455

E-mail: nano@nanoinst.com

www.nanoinst.com

(See MTS Systems Corporation)

National Aeronautics \& Space Administration, Lyndon B. Johnson Space Center \#1100, 1102

International Space Station Payloads Office

2101 NASA Road 1

Houston, TX 77058-3696

Tel: 281-244-8839

Fax: 281-244-8292

station.nasa.gov/science

The International Space Station (ISS)

will be an exciting laboratory for scientific and technological exploration. It will use modern technology and draw on past experience to continue human exploration and development of space for the benefit and enlightenment of all peoples and nations. As a unique multidisciplinary laboratory, testbed and observatory, the ISS is expected to provide researchers with an unprecedented undertaking in scientific, technological, and international research.
- National Electrostatics Corp. $\# 708$

P.O. Box 620310

7540 Graber Road

Middleton, WI 53562-0310

Tel: 608-831-7600

Fax: 608-256-4103

E-mail: nec@pelletron.com

www.pelletron.com

National Electrostatics Corp. manufactures a wide variety of ion beam systems from below $100 \mathrm{keV}$ to the hundreds of $\mathrm{MeV}$ region. These systems include complete materials analysis systems using $\mathrm{MeV}$ ion beams including RBS, PIXE, NRA, ERD and AMS. NEC also manufactures a wide range of beam handling and vacuum components including vacuum isolators for vacuum pumps.

\section{- Neocera. Inc. \#618}

10000 Virginia Manor Road

Suite 300

Beltsville, MD 20705-4215

Tel: $301-210-1010$

Fax: 301-210-1042

E-mail: gdoman@neocera.com www.neocera.com

Neocera, Inc. is a microelectronics and sensor-based technology company with leading edge materials expertise in thin film development and production. Neocera products include pulsed laser deposition systems, metal oxide thin films and thin film devices, cryogenic temperature controllers, cryogenic temperature sensors and HTS SQUID microscopy and microwave microscopy systems.

\section{New Wave Research \#204}

47613 Warm Springs Blvd.

Fremont, CA 94539

Tel: 510-249-1550

Fax: 510-249-1551

E-mail: lasers@new-wave.com www.new-wave.com

New Wave Research manufactures and delivers complete compact, high performance Nd:YAG laser micromachining systems. The QuikLaze operates at repetition rates up to $40 \mathrm{~Hz}$, with multiple wavelengths easily available from the infrared to the ultraviolet. Applications include marking, failure analysis, resistor trimming, LCD repair, material processing, micromachining and your application.
NFT-Nanofilm Technologie GmbH \#523

Anna-Vandenhoeck-Ring 5

37081 Göttingen

GERMANY

Tel: 49-551-999600

Fax: 49-551-9996010

E-mail: info@nanofilm.de

www.nanofilm.de

NFT specializes in advanced inspection technology best suited for surface, coating and thin film analysis. NFT's ellipsometers and Brewster angle microscopes achieve an outstanding lateral resolution of $1 \mu \mathrm{m}$ and provide a real-time video image of the sample. This is made possible by using the basic principle of ellipsometry or Brewster angle microscopy and using a $C C D$ camera as the detector. All NFT instruments feature state-of-the-art software with user-friendly interfaces and complete hands-off operation. NFT also supplies accessories for monolayer handling such as Langmuir film balances and active anti-vibration systems, with the capability to even dampen vibrations in the critical $1 \mathrm{~Hz}$ region effectively.

\section{Nicolet Instrument Corporation $\# 624$}

5225 Verona Road

Madison, WI 53711

Tel: 608-276-6100

Toll Free: 800-201-8132

Fax: 608-273-5046

E-mail: nicinfo@nicolet.com www.nicolet.com

Nicolet's Nexus ${ }^{\mathrm{TM}} 870$ research FT-IR spectrometer with its powerful Vectra-Piezo ${ }^{\mathrm{TM}}$ interferometer employs a set of piezoelectric transducers on the fixed mirror assembly to achieve high amplitude phase modulation. The Vectra-Piezo interferometer provides superior performance for step scan, time resolved, photoacoustic depth profiling and dynamic polymer rheology experiments. The Nexus ${ }^{\mathrm{TM}}$ FT-Raman module accessory offers the power and sampling simplicity of the near-infrared Raman technique combined with the flexibility and power of the high performance Nexus spectrometer.
- NORAN Instruments Inc. \#609

2551 West Beltline Highway

Middleton, WI 53562

Tel: 608-831-5125

Fax: 608-831-4461

E-mail: micro_info@noran.com www.noran.com

NORAN Instruments Inc. presents new answers for $\mathrm{x}$-ray microanalysis and microstructure applications. ORKID and PHASE ID systems for crystallographic analysis of electron backscattered diffraction patterns; NEW MAXray-ER for high resolution elemental $x$-ray analysis; SIGMA and VANTAGE $x$-ray microanalysis systems which feature our exclusive no-LN detectors or high resolution $\mathrm{LN}$-cooled detectors. All backed by the world's largest dedicated microanalysis support group.

\section{NYS Center for Advanced Thin Film Technology \#1104 CESTM}

251 Fuller Road, B-110

Albany, NY 12203

Tel: 518-437-8686

Fax: 518-437-8687

E-mail: lahill@csc.albany.edu www.albany.edu/cat

The Center acts as a research, development, education and economic outreach resource for industries, which manufacture, use or supply microelectronic, electronic, optoelectronic and photonic devices. The Center boasts a $200 \mathrm{~mm}$ tool set including 8 cluster tools and 30 standalone process cells. Extensive thin film characterization instruments are also available. Copper metalization and low temperature CVD are specialties at the Center.

\section{Olympus America Inc. \#309}

Scientific Equipment Division Two Corporate Center Drive Melville, NY 11747-3157

Tel: $800-446-5967$

Fax: 516-844-5112

E-mail: micro@olympus.com www.olympus.com

Olympus features the SZX12 research stereo microscope with the largest zoom ratio of 12.86:1; Provis AX70M microscope with multi-port observation tube for simultaneous attachment of image analysis and photographic (or digital) cameras; the MX general inspection microscope, and the OLY750 color video camera with 750 lines resolution. 
- Omicron Associates \#416 1226 Stoltz Road

Bethel Park, PA 15102

Tel: 412-831-2262

Fax: 412-831-9828

E-mail: omiassoc@sgi.net www.omicron-instruments.com

Omicron continues to excite the surface science community with product innovation. A recent agreement with the company Oxford Instruments Ltd. opens a new phase in the world of low temperature physics research. Integrating Omicron's established SPM expertise with Oxford's internationally recognized cryogenic experience will yield unique research equipment specifically designed for investigation of material properties below $5 \mathrm{~K}$. The practical objective is observation of surface structures/effects with atomic level resolution. A selection of the wide range of Omicron "Instruments for Surface Science" will be displayed including the TwinSNOM Transmission/ Reflection, Scanning Near-Field Optical Microscope.

\section{Oriel Instruments \#625}

150 Long Beach Blvd.

Stratford, CT 06615

Tel: 203-377-8282

Fax: 203-378-2457

E-mail: res_sales@oriel.com www.oriel.com

Oriel Instruments exhibits its Raman-PL system and FT-IR spectrometer. These modular instruments allow you to evaluate structural and chemical characteristics of solid, liquid, and gaseous samples. The instruments complement each other in the lab as materials emitting strong $\mathbb{R}$ signals tend to exhibit weak Raman signals and vice versa. Our flexible design allows a lab to reasonably consider using both of our economical instruments for materials evaluation.

\section{Osmic. Inc. \#703}

1788 Northwood Drive

Troy, MI 48084

Tel: 248-362-1290

Toll Free: 800-366-1299

Fax: 248-362-4043

E-mail: makowskeosmic.com www.osmic.com

Osmic manufactures multilayer coated $x$-ray and neutron optics. Osmic's distinctive optic assemblies are key components of many $\mathrm{x}$-ray analytical instruments. Now available for retrofit onto $\mathrm{Cu}, \mathrm{Cr}, \mathrm{Co}$ and
Mo diffractometers, Max-Flux ${ }^{\text {TM }}$ Optics offer high flux and good resolution from a well collimated monochromatic beam. Confocal Max-Flux ${ }^{\mathrm{TM}}$ Optics can simultaneously monochromatize and either focus or collimate a divergent $x$-ray beam. Ovonyx ${ }^{\mathrm{TM}}$ multilayers provide the best light element analysis in WD-XRF spectrometers. Osmic engineers and designs custom components and instrument assemblies.

\section{Oxford Applied Research \#424 \\ Crawley Mill, Witney \\ Oxon OX8 5TJ \\ UNITED KINGDOM \\ Tel: 44-1993-773575 \\ Fax: 44-1993-702326 \\ E-mail: sales@ oxfordar.demon.co.uk \\ www.oanesearch.co.uk}

Manufacturer of growth, processing and characterization equipment for semiconductor or thin film research including $\mathrm{RF}$ atom sources for highquality oxide/nitride growth and effective $\mathrm{H}$-atom precleaning of sensitive substrates. Also supplies e-beam evaporators, ECI nanocluster deposition sources for contact metallization or nanofabrication, ion sources for sputter deposition/ cleaning and electron guns.

\section{Oxford Instruments America, Inc.} \#417

Microanalysis Group

130A Baker Avenue Ext.

Concord, MA 01742

Tel: 978-369-9933

\section{Fax: 978-369-8287}

E-mail: maginfo@oxford.usa.com www.oxford-instruments.com Oxford Instruments is the world's leading supplier of integrated microanalytical tools for the materials and microelectronic industries. These tools are interfaced to scanning electron microscopes and include chemical microanalysis by EDX and WDX, grain orientation analysis and cathodoluminescence for optoelectronic device characterization. The XGT $2000 \mathrm{~W}$ is a stand-alone $\mathrm{x}$-ray microscope with a scanning stage providing combined transmitted $x$-ray imaging, quantitative microanalysis and elemental $x$-ray mapping capability all carried out with no vacuum involved.
Oxford Instruments America. Inc. \#419

Research Instruments Division 130A Baker Avenue Ext. Concord, MA 01742

Tel: 978-369-9933

Fax: 978-369-6616

E-mail: info@oxford.usa.com www.oxinst.com

Presenting systems for materials characterization, scanning probe microscopy and spectroscopy:

- Vibrating Sample Magnetometer, providing applied fields up to 16 tesla with sensitivities of $10^{-6} \mathrm{EMU}$

- MagLab ${ }^{\mathrm{EXA}}$, a low-cost measurement platform system using a variety of techniques; e.g., $\mathrm{AC}$ susceptibility, magnetization, transport and heat capacity measurements (adiabatic/relaxation)

- MagLabCMP, a highly-sensitive, micro-cantilever magnetometer

- CryoSTM, atomic resolution UHV variable temperature scanning tunneling microscopy over temperature range $<10 \mathrm{~K}$ to $300 \mathrm{~K}$

- CryosXM, versatile scanning probe microscope for STM, NSOM, AFM and other probe techniques in variable temperature from $1.5 \mathrm{~K}$ to $300 \mathrm{~K}$ and optional high magnetic field

- TOPS III PC Windows-based SPM contract electronics and software and more cryogenic and superconducting technology related equipment

- VTSTM variable temperature UHVSTM from $50 \mathrm{~K}$ to $100 \mathrm{~K}$

\section{- Oxford University Press \#923}

198 Madison Avenue

New York, NY 10016

Tel: 212-726-6063

Fax: 212-726-6441

E-mail: meh@oup-usa.org

www.oup-usa.org

The Defect Chemistry of Metal Oxides

(Smyth); Properties of Materials

(White); Polymer Chemistry: An

Introduction, 3rd Ed. (Stevens);

Smoke, Dust, and Haze: Fundamentals

of Aerosol Dynamics, 2nd Ed.

(Friedlander); Methods of X-ray and

Neutron Scattering in Polymer Science

(Roe); Effective Medium Theory

(Choy); An Introduction to

Homogenization (Cioranescu);

Electronic Processes in Organic

Crystals and Polymers, 2nd Ed

(Pope); Reagent Chemicals: American

Chemical Society Specifications, 9th

Ed.; Polymer Data Handbook (Mark).
- Ted Pella, Inc. \#721

P.O. Box 492477

4595 Mountain Lakes Blvd.

Redding, CA 96049-2477

Tel: 800-237-3526

Fax: 530-243-3761

E-mail: sales@tedpella.com

www.tedpella.com

Ted Pella, Inc. is a major supplier of accessories and instruments for electron microscopy. Our catalog and web site contain nearly 4,000 items including sputter and carbon coaters for SEM, a large selection of calibration standards, gold paste, photographic supplies, grid stainer and desiccators. Our NEWEST product is an economy model of a bench/desk vibration isolator which was introduced earlier this year at the MRS Spring Exhibit in San

Francisco.

\section{Performance Materials \#819}

4 Park Avenue

Hudson, NH 03051-3927

Tel: 800-700-1283

Fax: 603-598-9126

E-mail: info@

performancematerial.com www.PerformanceMaterial.com

Performance Materials manufactures crucibles and plates of CVD pyrolytic boron nitride ( $\mathrm{PBN}$ ) and silicon carbide ( $\mathrm{SiC}$ ) for customers in the silicon, gallium arsenide, microwave and semiconductor industries worldwide.

\section{Perkin Elmer \#917, 919}

761 Main Avenue Norwalk, CT 06859

Tel: 203-762-4000

Fax: 203-762-4054

E-mail: info@perkin-elmer.com perkin-elmer.com/ai

The LAMBDA 900 is the ideal tool for research, design, manufacturing and QC where UV/VIS/ NIR spectroscopy is the technique of choice. Characterization of thin film coatings, mirrors, high performance optics and many other applications can be accomplished with one instrument. Enhanced UVWINLAB software provides a simple but powerful user interface for the LAMBDA 900. 
- Pfeiffer Vacuum \#320

24 Trafalgar Square

Nashua, NH 03063

Tel: 603-578-6500

Toll Free: 800-248-8254

Fax: 603-578-6550

E-mail: contact@ pfeiffer-vacuum.com

www.pfeiffer-vacuum.com

Pfeiffer Vacuum is a global leader in the production of vacuum products used in a broad spectrum of high technology applications including electronics, materials science and research. Products include a complete line of turbomolecular, mechanical and dry vacuum pumps, quadrupole mass spectrometers, residual gas analyzers, helium leak detectors, compact gauges, valves, flanges and fittings.

\section{Philips Analytical \#1000, 1002}

12 Michigan Drive

Natick, MA 01760

Tel: 508-647-1100

Fax: 508-647-1111

E-mail: diane.donati@ philips.com

www.analytical.philips.com

Philips Analytical is the leading manufacturer of $x$-ray diffraction and $\mathbf{x}$-ray fluorescence equipment as well as wafer analyzing and photoluminescence mapping systems. Information is available on all product lines. Philips Analytical is ISO 9001 certified. We adhere to the most stringent of the three ISO classifications which requires an established, effective quality system be in place.

\section{Philips Electron Optics \\ (See FEI Company/Philips \\ Electron Optics)}

\section{Physical Electronics \#811, 813}

6509 Flying Cloud Drive

Eden Prairie, MN 55344

Tel: 612-828-6100

Fax: 612-828-6322

E-mail: marketing@phi.com www.phi.com

Physical Electronics (PHI) develops, manufactures and markets surface analysis instrumentation to perform auger electron spectroscopy (AES), $x$-ray photoelectron spectroscopy (XPS), secondary ion mass spectrometry (SIMS) and time-of-flight SIMS. These techniques characterize the top few atomic layers of a surface, providing spatially resolved information about elemental composition, chemical bonding and molecular structure.
- PIEZOMAX Technologies, Inc. $\# 1204$

505 South Rosa Road

Madison, WI 53719

Tel: $608-238-4850$

Fax: 608-238-5120

E-mail: draeger@piezomax.com www.piezomax.com

PIEZOMAX Technologies, Inc. manufactures precision nanopositioners, driver and feedback electronics, and ProbeMAX ${ }^{\mathrm{TM}}$ carbon nanotube tips for scanning probe microscopy. Nanopositioners can be designed for $\mathrm{X}, \mathrm{XY}$, or $\mathrm{XYZ}$ motion, with closed loop function, 100 micrometers or greater range of motion, position resolution finer than 1 angstrom, and resonant frequency as high as $7 \mathrm{kHz}$. The positioners utilize flexure hinges designed by finite element analysis, and are driven by piezostack actuators with capacitance position sensing. Applications include surface metrology and profilometry, precision machining, optical transmission control, laser positioning, scanning probe microscopy, electron-beam positioning, mask and wafer alignment, nanoindentation techniques, and molecular biology research.

\section{Polytec PI, Inc. \#421}

23 Midstate Drive, Suite 212

Auburn, MA 01501

Tel: 508-832-3456

Fax: 508-832-0506

E-mail: info@polytecpi.com www.polytecpi.com

Polytec PI offers a wide range of laser products including excimers, cw and pulsed Nd:yag, Ti: sapphire, ruby, argon, $\mathrm{HeNe}$, diode lasers and other tunable sources available with our new diode array spectrometers to cover 350 to 2,200 $\mathrm{nm}$ at a resolution as low as $0.06 \mathrm{~nm}$. Polytec can cover the many applications in the scientific and industrial field (spectroscopy, holography, PIV, interferometry, ablation, micromaching, Lidar, etc.)

Praxair Specialty Ceramics \#224

16130 Wood-Red Road NE

Suite 7

Woodinville, WA 98072

Tel: 425-487-1769

Fax: 425-487-1859

E-mail: Ron_Ekdahl@ praxair.com

www.praxair.com

Praxair Specialty Ceramics manufactures a wide array of metallic oxide powders and deposition materials.
Multi-component oxide powders are produced with the patented technology Combustion Spray Pyrolysis (CSP), a solution synthesis process which yields fine homogeneous powders. Deposition materials include electron beam evaporation ingots, evaporation pellets and sputtering targets up to 13 inches in diameter. Standard and specialized products are offered for research and large scale production.

Common markets served include superconductor, solid oxide fuel cell, ferroelectric, and photovoltaic applications.

\section{- Princelon Gamma-Tech, Inc. $\$ 804$ \\ C/N 863 \\ Princeton, NJ 08540-0863 \\ Tel: 609-924-7310 \\ Fax: 609-924-1729 \\ E-mail: sales@pgt.com \\ www.pgt.com}

On display will be PGT's full line of energy dispersive $x$-ray microanalysis systems for electron column instrumentation. Included in this are the new Avalon 4000 and Avalon 8000 microanalysis systems. The IMIX family of microanalysis systems with superior advanced $x$-ray and imaging capabilities will also be on hand for demonstrations.

\section{- Princeton Scientific Com. \#604}

\section{P.O. Box 143}

Princeton, NJ 08542

Tel: 609-924-3011

Fax: 609-924-3018

E-mail: psc1@IDT.com

www.princesci.com

Princeton Scientific Corp. offers various metal and oxide single crystals, like $\mathrm{W}, \mathrm{Mo}, \mathrm{Au}, \mathrm{SrTiO}_{3}, \mathrm{TiO}_{2}$ and $\mathrm{MgO}$, as well as a number of III-V materials such as $\mathrm{GaAs}, \mathrm{GaP}, \mathrm{InSb}$, InAs, InP, and more. Cutting and polishing services are also provided. Also on display is a precision wire saw which allows for a very accurate cutting process and yields surfaces with almost 'lapped' quality.

\section{Proxitronic/Stanford Computer Optics \#108}

3193 David Avenue

Palo Alto, CA 94303

Tel: 650-494-7797

Fax: 650-494-6711

E-mail: 103013.1637@

\section{compuserve.com}

Manufacturer of microchannel plate and diode image intensifiers and spectral converters for wavelength range from 110 to 900 nanometers and light amplification from $10^{1}$ to $10^{9}: 1$. Used in applications in vacuum UV, ellipsometry, spectrometry, plasma research, LIF, particle analy sis, optical measuring instrumentation and intensified $\mathrm{CCD}$ cameras where low light, down to single photon levels (nanoLUX), must be imaged, analyzed or converted. Spectral conversion from UV to visible. Also intensified, gated cameras with shutter speeds as fast as $\mathbf{2 0 0}$ picoseconds.

\section{- Pure Tech \#217}

A Subsidiary of Williams Advanced Materials, Inc. P.O. Box 1319

Commerce Drive

Carmel, NY 10512

Tel: 914-878-4499

Fax: 914-878-4727

www.puretechinc.com

Pure Tech is an ISO 9002 certified American manufacturer of high purity materials for sputtering and evaporation. Pure Tech produces both standard and custom materials for R\&D as well as production applications. In-house capabilities include vacuum melting, inert gas hot pressing, metal and ceramic machining, custom-designed backing plates, target bonding, and analytical services.

\section{- Quad Group. Inc. \#613}

1815 South Lewis Street

Spokane, WA 99224

Tel: $509-458-4558$

Fax: 509-458-4555

E-mail: info@quadgroupinc.com www.quadgroupinc.com A Complete Material Science Test Lab (and Coatings Lab) in a Box...Romulus III-A executes tensile stress/strain (eng. and true), or in seconds switches to Flexural Modulus of Rupture ( 3 or 4 point loading) with automatic operation and parameter reporting-no operator judgment or errors. For the coating test lab, execute optional stud pull adhesion, shear, peel, tear, blade cutting, scratch, for electronics and functional coatings, or disk and head coatings. And, microrange tests for multiple microelectronic applications. NEW, our instrumented indentation tester, Alexandra I, measures hardness, Young's Modulus, yield strength and strain hardening in minutes. Uses proven Hertzian concepts and simple polished metallurgical sample prep. 
Excellent for characterizing all materials above 5 micrometers. Valuable in determining properties as a function of depth, such as with IBMM and composites. Wonderful teaching lecture aid.

\section{- Quantum Design, Inc. $\# 407,409$}

11578 Sorrento Valley Road

San Diego, CA 92121

Tel: $858-481-4400$

Fax: 858-481-7410

E-mail: info@quandsn.com www.quandsn.com

Quantum Design manufactures its magnetic property measurement system (MPMS) and physical property measurement system (PPMS).

The MPMS SQUID magnetometer is the industry standard for ultrasensitive magnetic measurements. The PPMS is an innovative device designed to provide automated magnetic, torque, transport, specificheat and user designed measurements over a broad range of temperatures and applied magnetic fields.

\section{Quesant Instrument Corporation \#225}

29397 Agoura Road, Suite 104

Agoura Hills, CA 91301

Tel: 818-597-0311

Fax: 818-991-5490

E-mail: quesant@quesant.com www.quesant.com

Quesant produces easy-to-use, innovative and affordable scanning probe microscopes. Q-Scope ${ }^{\mathrm{TM}}$ SPMs offer multiple scanning modes and include innovative features such as our patented Isotopic Focal System ${ }^{\mathrm{TM}}$, fast scanning (up to 10 times faster than other SPMs), an open architecture for optimal sample access, and Windows-based software. All at prices that make sense.

Radiant Technologies, Inc. \#1009 2021 Girard, SE, Suite 100 Albuquerque, NM 87106 Tel: $505-842-8007$

Toll Free: 800-289-7176

Fax: 505-842-0366

E-mail: radiant@ ferrodevices.com

www.ferrodevices.com

Radiant Technologies announces the introduction of our Precision Materials Analyzer Family which extends the precision, flexibility and ease of Radiant's testers into the megahertz measurement range. The Precision Pro introduces $1 \mu \mathrm{s}$ ground hardware driven by
Windows NT V4.0 ${ }^{\mathrm{TM}}$ user interface, revolutionary software design that provides exceptional freedom to design, conduct and review tasks associated with any materials experiment. The Precision Workstation serves the test and measurement role in the laboratory. Radiant Technologies also provides World Wide Web customer support and universal user communication capabilities, memory technology, engineering services and clean room facilities.

\section{Refining Systems, Inc. \#105 \\ E-mail: bdg@reveo.com \\ www.reveo.com}

P.O. Box 72466

Las Vegas, NV 89117

Tel: 702-368-0579

Fax: 702-368-0933

www.refiningsystems.com

Refining Systems manufactures sputtering targets and evaporation materials for thin film deposition, platinum crucibles and labware for crystal growth, and various fabricated products such as tubing, wires, ribbons, foils, etc. Visit our booth at the MRS Fall Exhibit in Boston.

\section{Renishaw Inc. \#621}

623 Cooper Court

Schaumburg IL 60173

Tel: 847-843-3666

Fax: 847-843-1744

E-mail: raman.usa@ renishaw.com

www.renishaw.com

Renishaw will demonstrate exciting instrument developments in Raman microscopy and process Raman analyzers. Renishaw is the recognized world leader in Raman microscopy. Very high efficiency spectrometers allow superb performance from the deep UV to the NIR including direct 2-D Raman and photoluminescence imaging. Fast new process Raman instruments suitable for applications involving multiple fiber optic probes, rugged and high temperature probes will also be displayed.

\section{Research and PVD Materials Corporation \#716 \\ P.O. Box 4796 \\ Wayne, NJ 07474 \\ Tel: 973-575-4245

$$
\text { Fax: 973-575-6460 }
$$

Research and PVD Materials Corporation manufactures a wide variety of highly characterized, high purity materials for the diverse and sophisticated requirements of the semiconductor, electronics, electro-optic and related research communities. Products from this single-quality source include but are not limited to sputtering targets, thin-film deposition materials, fabricated forms of specialty and exotic metals, alloys, ceramics, intermetallics, custom fabrications and "one off" components.

\section{Reveo, Inc. \#422}

8 Skyline Drive

Hawthorne, NY 10532

Tel: 914-345-9556

Fax: 914-345-2095

Reveo's technical problem-solving service is the key to your R\&D success. We have proven our effectiveness in solving problems and providing advanced solutions in diverse fields. Our service includes frontier research in fundamental problems, technology development and prototyping, technology consulting, and intellectual property licensing. For more information on our areas of expertise please visit our website at www.reveo.com

\section{Rheometric Scientific, Inc. \#821}

One Possumtown Road

Piscataway, NJ 08854

Tel: 732-560-8550

Fax: 732-560-7451

E-mail: marketing@rheosci.com www.rheosci.com

Rheometric Scientific, Inc. designs, builds, markets and sells the broadest line of test instruments available for materials characterization. The product line includes rheometers, viscometers, thermal analyzers, tensile testers and on-line process control monitors. RSI has a worldwide network of sales, applications engineering and technical support personnel to help customers solve material problems. RSI is ISO 9001 certified.

\section{BHK Technology, Inc. \#808}

1050 E. Maple Road

Troy, MI 48083

Tel: 248-577-5426

Fax: 248-577-5433

E-mail: info@rhk-tech.com www.rhk-tech.com

RHK Technology, the leading supplier of SPM equipment for research, will feature our NEW DSP-based control system with the SHARC. We will be demonstrating the new controller and software features along with our Model UHV 300 Variable Temperature UHV STM system throughout the show. The
UHV 300VT is available with $\mathrm{LHe}$ or $\mathrm{LN}_{2}$ cooling options and is the only commercial "Beetle" design offering variable temperature and in situ tip change. Our NSOM microscope from Nanonics will also be on display along with our Cathodic Arc Pulsed Plasma Deposition package and full compliment of SPM control accessories and interface options. We will also be demonstrating the world's lowest cost $(\$ 7,900)$ turnkey, atomic resolution STM system, the easyScan from NanoSurf AG.

\section{- Riber, Inc. \#525}

3880 Park Avenue

Edison, NJ 08820

Tel: 732-603-0680

Fax: 732-603-8611

E-mail: riber@isainc.com

www.riber.com

Riber is the leading supplier of epitaxial reactors (MBE, CBE, MOMBE and UHV/CVD for SiGe) and components. Reactors range from the new R\&D system for nitrides, Model Compact 21, through fully automated multiwafer production for $4 \times 4$ inch and $9 \times 4$ inch.

Components include valved cracker cells for phosphorus and arsenic and high precision gas flow lines for $C$ doping for $\mathrm{NH}_{3}$ for nitrides.

Rigaku/USA, Inc. \#406, 408

9009 New Trails Drive

The Woodlands, TX 77381

Tel: 281-367-2685

Fax: 281-364-3628

E-mail: info@rigaku.com

www.rigaku.com

Rigaku provides the world's most complete line of $x$-ray diffraction and fluorescence instruments including: desktop and laboratory powder diffractometers, highresolution thin film diffractometers, $x$-ray reflectometers, diffraction and topography tools for the semiconductor industry, small-angle scattering systems, rotating-anode generators, sequential and simultaneous $x$-ray spectrometers, TXRF systems, and wafer analyzers.

RJ Lee Instruments Limited \#300, 302

515 Pleasant Valley Road

Trafford, PA 15085

Tel: 724-744-0100

Fax: 724-744-0506

E-mail: pssales@rjleeinst.com www.rileeinst.com

RJ Lee Instruments Limited, "The Applications Specialists," designs, manufactures and services fully 
integral microanalysis systems (SEM/EDX) for specific and general applications. Our tightly integrated products provide maximum flexibility, speed and reliability. Exclusive Automated Feature Analysis ${ }^{\mathrm{TM}}$ (AFA) provides completely unattended microanalysis and detailed reports.

\section{- Rohm and Haas Company \#311 \\ 60 Willow Street \\ North Andover, MA 01845 \\ Tel: 978-557-1700 \\ Fax: 978-557-1701}

Rohm and Haas Company (formerly Morton International) is the leading manufacturer of high purity metalorganic sources for MOVPE and related growth technologies. Our trimethylgallium, trimethylaluminum, trimethylindium and magnesium dopant sources deliver peak film performance for gallium nitride applications.

\section{RÖNTEC USA, InC. \#112}

20 Main Street

Acton, MA 01720

Tel: 978-266-2900

Fax: 978-929-9313

E-mail: sales@rontecusa.com www.rontecusa.com

RÖNTEC will show its new Macres Award-winning EDX detector technology...the XFlash ${ }^{\oplus}$, a reliable, high performance silicon drift chamber $x$-ray detector (SDCD). XFlash ${ }^{\circledR}$ is a small, low cost, LN2 free, room temperature x-ray detector for SEMs and diffractometers which can process up to 1 million cps with excellent energy resolution. RÖNTEC offers complete Windows-based EDS systems, its own advanced design, low consumption LN2 cooled UHV detectors and upgrades to most existing EDX detectors.

\section{Schott Glass Technologies Inc.} $\# 617,619$

400 York Avenue

Duryea, PA 18642

Tel: 570-457-7485

Fax: 570-457-6960

E-mail: sgt@sg23L.attmail.com

www.schottglasstech.com

Schott Glass Technologies features technical glasses and glass ceramics for industrial and scientific uses. Industries served include electrooptics, photonics, aerospace, astronomy, ophthalmic, semiconductor, government sectors, and others. We melt glasses in various types of cru- cibles and continuous tanks each with daily outputs between one-half liter and many tons, and have a glass research and development laboratory staffed with experts in physics, engineering and materials science.

\section{Scintag, Inc. \#325}

10040 Bubb Road

Cupertino, CA 95014

Tel: 408-253-6100

Toll Free: 800-TEL-XRAY

Fax: 408-253-6300

E-mail: sales@scintag.com www.scintag.com

Scintag provides system solutions to the diverse needs of the $x$-ray diffraction community. Be it quality control, research or teaching, Scintag offers the right system for every application and budget. Scintag offers standand and customized system designs, accessories and Windows NT-based software packages.

\section{SciVision \#1022}

200 Wheeler Road

Burlington, MA 01803

Tel: $781-272-4949$

Fax: 781-272-6868

www.scivision.com

Headquartered in Burlington, Massachusetts, SciVision was founded in 1992 to create software that delivers mission-critical information to the desktops of research and development scientists. SciVision has released several products relating to glass, polymers, and analytical chemistry. The software includes large, relational databases, property prediction tools, visualization tools, and discipline-specific analytical tools.

SELA USA, Inc. \#201, 203

1030B East Duane Avenue Sunnyvale, CA 94086

Tel: 408-736-3700

Fax: 408-524-5439

E-mail: info@sela.com www.sela.com

Incorporating the latest development in microcleaving technology, the SELA MC500 System has been designed to allow fully automatic, reliable, and speedy cross-sectioning of both integral die and wafer level samples. An innovative approach facilitates processing of segments down to a minimum size of $4.2 \times 2.1$ $\mathrm{mm}$, and results in two accurate, completely artifact free, mirrorimage sections. Dedicated software enables automatic mapping and planning of a single or multiple targets (optional) and off-loading for immediate inspection. This accessibility, together with high throughput (15 min/sample), high accuracy $(0.5 \mu)$, and excellent quality crosssections, significantly reduces the diagnostic cycle for both failure analysis and process monitoring. The SELA TEMstation allows automatic, reliable and rapid TEM sample pre-preparation. This standalone unit produces a sample thinned to 20 microns in 20 minutes, and features the capability to control and program the target location within this width. The completed sample is automatically packaged for direct loading into both a FIB workstation and TEM holder.

\section{Sigma Instruments \#725}

1318 Duff Drive

Fort Collins, CO 80524

Tel: 970-416-9660

Fax: 970-416-9330

E-mail: sales@sig-inst.com www.sig-inst.com

Sigma Instruments specializes in instrumentation for the control of vacuum processes and thin film deposition. The SQM-160

Deposition Monitor provides multisensor monitoring in a low cost package. Our new SQC-122 Deposition Controller provides an easy-to-use solution for basic deposition control. The powerful SID-142 Deposition Controller can monitor and control up to four codeposition sources.

\section{Silicon-MDT Ltd. \#107}

P.O. Box 50

103035 Moscow

RUSSIA

Tel: 7-095-532-5535

Fax: 7-095-532-9338

E-mail: info@siliconmdt.com www.siliconmdt.com

Silicon-MDT Ltd. is a manufacturer of the cantilevers and calibration gratings for scanning probe microscopy. We develop and fabricate customized micromechanic devices for OEMs and special scientific applications. Ultimately optimized technology allows us to achieve high quality for the lowest prices on the market.
- Silicon Sense, Inc. \#1006, 1008

110 Daniel Webster Highway

Nashua, NH 03060-5252

Tel: 540-547-3893

Fax: 540-547-2120

E-mail:npcook@ monumental.com

www.siliconsense.com

MEMS/MST, semiconductor and hybrid foundry services, with packaging; RIE and ion milling processing; silicon wafers, both $\mathrm{Cz}$ (2 inch to $300 \mathrm{~mm}$ diameter) and $\mathrm{Fz}$ ( 2 inch to $100 \mathrm{~mm}$ diameter) with and without thin films, epitaxy or metallization, as prime, monitor/test, single/double-side polished; $\mathrm{Ge}$ and GaAs materials; and RotoTool ${ }^{\mathrm{rM}}$ equipment and services; all offered for R\&D through large volume production applications. Small quantity needs, for all of the above, are served.

\section{SKION/nnoVac Corporation \#411, 413}

50 Harrison Street

Hoboken, NJ 07030

Tel: 201-963-5450

Fax: 201-963-5449

E-mail: info@skion.com www.skion.com

InnoVac is a manufacturer and distributor of custom vacuum chambers, systems and components. Components include deposition systems ranging from magnetron sputtering, evaporation and ion sources to specialized substrate handling devices including load lock assemblies and linear motion stages. $\mathrm{SiC}$ substrate heaters for use in oxygen environments and liquid nitrogen cooling stages are also available.

\section{- Solartron Inc. \#212}

964 Marcon Blvd., Suite 200

Allentown, PA 18103

Tel: $610-264-5034$

Toll Free: 800-225-5765

Fax: 610-264-5329

E-mail: lab_info@solartron.com www.solartron.com

Solartron is a leading supplier of materials, electrochemical and impedance analysis systems and software. Solartron products set the world standard in high performance measurements for batteries and energy storage devices. The Solartron Frequency Response Analyzers offer the highest accuracy, repeatability and versatility in the market today. Solartron offers total system solutions for analysis of electrochemical, corrosion and materials 
characterization applications across a range of markets and industries. Solartron also provides consultation, technical support, applications engineering, test cells, accessories and product support.

SOPRA, Inc. \#816

P.O. Box 2619

33 Nagog Park

Acton, MA 01720-6619

Tel: 978-263-2520

Fax: $978-263-2790$

www.sopra-sa.com

Manufacturer of high accuracy and precision instrumentation and equipment for thin film characterization, ranging from in situ instruments for monitoring deposition and growth process, to tabletop for advanced R\&D applications, to fully automated equipment used in the manufacturing of semiconductors and flat panel displays. The SOPRA Thin Film Characterization Station combines variable angle spectroscopic ellipsometer with grazing incidence angle $x$-ray reflectometer for very precise and accurate characterization of layers and materials. IR option extends spectral range up to $30 \mu \mathrm{m}$ wavelength. SOPRA's new DUV spectroscopic ellipsometer covers the $145 \mathrm{~nm}$ to $300 \mathrm{~nm}$ spectral range for characterization of layers and materials at $157 \mathrm{~nm}, 193 \mathrm{~nm}$ and $248 \mathrm{~nm}$ wavelengths. Developer and manufacturer of high energy excimer lasers for annealing and processing of materials such as amorphous silicon used in the manufacturing of flat panel displays. Manufacturer of very high resolution spectrometers for optical spectroscopic characterization of materials or for very fine characterization of laser spectral lines.

\section{- South Bay Technology. Inc.} $\$ 501.503$

1120 Via Callejon

San Clemente, CA 92673

Tel: $949-492-2600$

Toll Free: $800-728-2233$

Fax: 949-492-1499

E-mail: sbt@southbaytech.com www.southbaytech.com

South Bay Technology, Inc., a leading manufacturer of sample preparation equipment, has acquired the assets of VCR Group, Inc. VCR Group pioneered the development of the Dimpler for TEM sample preparation and has remained a dominant force in the EM products industry. South Bay Technology will continue the production of the Dimpler D500i as well as the new $X L A / 2000$ computer-controlled ion milling system and the IBSE 250 for ion beam sputtering and etching. The acquisition of the VCR Group's products complements South Bay's current line of sample preparation products which include an extensive offering of products for lapping, polishing, cutting, and crystal orientation.

\section{SPECS USA, Inc. \#518}

Surface Analysis Division 635 South Orange Avenue Sarasota, FL 34236

Tel: 941-362-4877

Fax: 941-364-9706

E-mail: support@specs.com www.specs.de

SPECS will present its new high performance UHV surface analysis components at the MRS Fall Meeting which include the high resolution electron energy analyzer, PHOIBOS 100/150; high performance, low energy electron diffraction optics, Er-LEED 100/150; and the high resolution electron energy loss spectrometer, DELTA 0.5.

SPECS, with over 15 years of experience in the field of ultra-high vacuum products, is a leading manufacturer of surface analysis components and systems for XPS, UPS, ISS, AES, SAM, SEM, LEED, EELS, SIMS, SNMS, MBE components, effusion cells, plasma sources, synchrotron beam lines and magnetic sectorfield mass spectrometers.

\section{SPI Supplies \#101 \\ P.O. Box 656}

569 E. Gay Street

West Chester, PA 19381-0656

Tel: $610-436-5400$

Fax: 610-436-5755

E-mail: spi2spi@2spi.com

www.2spi.com

Structure Probe, Inc. is an independent analytical laboratory providing innovative electron microscopy and surface analysis services for solving materials science problems including HTC materials, diamond coatings and complex polymer systems. SPI Supplies: Sample preparation instruments and consumable supply items for electron microscopy and surface analysis laboratories. Exclusive SPI-Module ${ }^{\mathrm{TM}}$ sputter / carbon coating system, Plasma Prep $\Pi^{\mathrm{TM}}$ etcher/asher, Plasma Prep $\mathrm{X}^{\mathrm{TM}}$ parallel plate all solid-state plasma etcher for anisotropic etching and "Tacky Dot" slides.
- Springer-Verlag New York, Inc. \#827

175 Fifth Avenue

New York, NY 10010

Tel: $212-460-1500$

Fax: 201-348-4505

E-mail: custserv@ springer-ny.com

www.springer-ny.com

Major new titles for your perusal include: Nitride Semiconductors and Devices by Morkoc, Ceramics by Munz \& Fett, Computational Materials Science by Ohno \& Kawazoe, Semiconductor Physics $7 e$ by Seeger, Femtosecond Technology, and Amorphous Silicon. Take advantage of Springer's $20 \%$ discount on these and all other Springer books (expires January 3, 2000). Free samples of related journals are also available.

- STAIB Instruments, Inc. \#717 813 Diligence Drive, Suite121E Newport News, VA 23606-4285

Tel: 757-873-0099

Fax: 757-873-0130

E-mail: staib-us@ staib-instruments.com

www.staib-instruments.com Designs and manufactures compact, high-performance electron-optical equipment for in situ material analysis, including: electron sources, RHEED systems and RHEED energy analyzer to study structure and quality of thin films; PhotoEmission Electron Microscopy (PEEM), a new technique for dynamic studies of chemical distribution with high time and space resolution; and electron spectrometers for Auger, XPS and UPS analytical surface studies.

- Strem Chemicals, Inc. \#321 7 Mulliken Way Newburyport, MA 01950-4098 Tel: 978-462-3191

Fax: 978-465-3104

E-mail: info@strem.com www.strem.com

Strem Chemicals manufactures a wide variety of chemicals for research and commercial scale production for the materials community including metals, inorganics and organometallics. Volatile precursors for MOCVD include metal alkyls, alkyl amides, carbonyls, alkoxides, beta-diketonates, fluorinated derivatives, organometallics and electronic grade chemicals as well as new mixed alkoxide/beta-diketonate complexes for metal and mixed metal oxide deposition. Custom synthesis services are also provided.

\section{Structured Materials Industries, Inc./ Nanopower Enterprises Inc. \#324}

120 Centennial Avenue Piscataway, NJ 08854-3908 Tel: 732-885-5909

Fax: 732-885-5910

E-mail: sales@ structuredmaterials.com

www.StructuredMaterials.com Structured Materials is a developer and provider of OXIDE Metal

Organic Chemical Vapor Deposition (MOCVD) processes and equipment (components as well as fully automated systems) as well as providing film deposition development services, specializing in complex oxides such as ferroelectrics, dielectrics, superconductors and display materials. We also represent COVA Technologies Liquid Delivery Flash Evaporator systems. Nanopowder Enterprises produces very high surface area nanopowders with minimum aggregation and sells processing equipment for such nanopowders.

\section{Superconductive Components, Inc. \#707}

1145 Chesapeake Avenue

Columbus, $\mathrm{OH} 43212$

Tel: 614-486-0261

Fax: 614-486-0912

E-mail: sales@ superconductivecomp.com

www.superconductivecomp.com $\mathrm{SCI}$ manufactures ceramic powders, sputtering targets, evaporation materials and engineered ceramics for the research and commercialization of superconductors, solid oxide fuel cells, ceramic membranes, lithium ion batteries, dielectrics, electrochemical and other applications. The company's patented processes for YBCO and BSCCO powder assure consistency and high performance in thin films and wires. Powders are available with purity to $99.999 \%$ and particle size down to 0.1 microns. Visit our booth for a demonstration of high temperature superconductivity.

\section{SURFACE \#521}

Rheinstrasse 7

D-41836 Hueckelhoven

GERMANY

Tel: $49-2433-970305$

Fax: $49-2433-970302$

E-mail: surface@ compuserve.com

www.surface-tec.com

SURFACE is known for its advanced laser deposition systems 
and components. The LASER-Star cluster PLD system is the first production-oriented, UHV-based PLD system. It combines high performance PLD technology with advanced UHV multichamber equipment design. The system is an excellent production platform for HTSC deposition of SQUID devices and filters-substrate sizes up to $6^{\prime \prime}$ can be deposited. SURFACE oxygen resistant heaters are available from 1 " to 8 " substrate diameter up to $800^{\circ} \mathrm{C}$ or $1000^{\circ} \mathrm{C}$ for $\mathrm{HV}$ or UHV applications. SURFACE also offers a new plasma-related product, THE SOURCE. THE SOURCE is a new hollow cathode high-density plasma source for PECVD which is ideal for industrial needs-large plasma volume, easy-to-use DC technology, upgradable to several $\mathrm{m} 3$ plasma volume, and low price level. THE SOURCE delivers the plasma density and ion energy of ECR sources in a much larger volume and for a much lower price.

The newest product is a complete new line of MW power supplies.

The POWER HEAD design incorporates the complete MW power supply in the magnetron head. The result is the most compact MW generator on the market. The advantage is not only the compactness but also the maintenance friendly setup and the low price. It is designed as a switch mode power supply and has a low ribble output with pulse capability. 1,2 , and $6 \mathrm{~kW}$ units are available.

Surface/Interface, Inc. \$524

260 Santa Ana Court

Sunnyvale, CA 94086

Tel: 408-732-7111

Fax: 408-732-7191

E-mail: sii@surfaceinterface.com www.surfaceinterface.com

Surface/Interface provides innovative products to industry from its Vacuum Products and Metrology Groups. The Vacuum Products Group focuses on OEM, end-user and R\&D markets specializing in wafer/sample transfer systems and loadlocks, magnetic linear and rotary feedthroughs for $\mathrm{UHV} / \mathrm{HV}$ as well as spectroscopy-based thin film thickness monitor systems for the media industry. The Metrology Group offers the Stylus NanoProfilometer ${ }^{\mathrm{TM}}$ (SNP), a 3D non-destructive $C D$ measurement tool for semiconductor and mask producers.
- SVT Associates. Inc. \#608

7620 Executive Drive

Eden Prairie, MN 55344

Tel: 612-934-2100

Fax: 612-934-2737

E-mail: svta@svta.com

www.svta.com

SVT Associates, Inc. offers a full range of thin film deposition and process monitoring components and systems including MBE systems for III-V, II-VI and SiGe; UHV/CVD for SiGe production; SiC CVD and bulk growth; metal/oxide CVD; and UHV sputtering. Newly developed A1GaInN MBE systems guarantee material specifications. Components include RF plasma sources and thermal effusion cells. Contact us for nitride Epi-service.

\section{Sycon Instruments, Inc. \#316 \\ 6757 Kinne Street \\ E-mail: garyh@telemrk.com \\ www.telemrk.com}

East Syracuse, NY 13057

Tel: $315-463-5297$

Fax: 315-463-5298

E-mail: sales@sycon.com

Sycon Instruments, Inc. is a manufacturer of thin film deposition monitors and controllers utilizing the quartz crystal sensing techniques. A complete line of HV and UHV sensors and shutters for these products are available. A multi-pocket E-beam source indexer for the control of 4-and 6-pocket E-beam guns is also available from Sycon.

\section{TA Instruments, Inc. \#223}

109 Lukens Drive

New Castle, DE 19720

Tel: $302-427-4000$

Fax: 302-427-4001

E-mail: info@tainst.com

www.tainst.com

TA Instruments is the world's leading supplier of thermal analysis and rheology testing equipment. Its products include DSC, modulated DSC, TGA, HiRes and modulated TGA, simultaneous DSC/TGA, TMA, DMA, and DEA. The rheology products measure the viscosity and rheology of samples from water to solids and everything in between. The company offers a large network of local technical support.

Tel: $215-625-8900$
Taylor \& Francis \#823

325 Chestnut Street

Philadelphia, PA 19106

Fax: 215-625-2940

E-mail: info@

taylorandfrancis.com

www.taylorandfrancis.com

Taylor \& Francis is an international publisher of academic books and journals. Stop by our booth to

browse through our new titles, bestsellers, and our wide variety of journals for the materials research community.

\section{Telemark \#113}

51 Whitney Place

Fremont, CA 94539

Tel: 510-770-8700

Fax: 510-70-8879

Telemark manufactures the widest range of electron beam sources and power supplies, and a broad range of accessories such as quartz crystal deposition controllers, optical monitors, indexers and feedthroughs. An important new product is the Arc-

Free Evaporation System consisting of an e-beam source, which is significantly different than traditional sources, together with a power supply. This set of components can completely overcome hostile coating environments; i.e., particulate rain and heavy ion background.

\section{Textron Systems \#106}

201 Lowell Street, Room 2117

Wilmington, MA 01887

Tel: 978-657-2958

Fax: 978-657-2930

E-mail: mtreasur@ systems.textron.com

Boron-coated Components for Semiconductor Fabrication Applications. Boron-coated graphite offers many advantages for various components in semiconductor processing equipment such as ion implanters and plasma etchers. Textron's unique CVD process enhances the bonding between high purity graphite and amorphous boron resulting in lower particulate and chemical contamination. Examples are presented of ion extraction slits, ion sources, ion optics components and chamber liner material. Textron Systems is a leading supplier of advanced materials including boron and silicon carbide fibers and composites.

\section{Theiss Hard- and Software} \#1207

Dr-Bernhard-Klein-Str. 110

D-52078 Aachen

\section{GERMANY}

Tel: 49-241-5661390

Fax: 49-241-9529100

E-mail: theiss@mtheiss.com

www.mtheiss.com

$M$. Theiss Hard- and Software offers software and hardware for optical spectroscopy. The focus is on thin film analysis and design. Spectrum simulation programs for research, design and production control are developed which may be coupled to spectrometers recording reflectance and transmittance of the layer stacks simultaneously.

\section{- Thermionics Vacuum Products \#1011, 1013} 231-B Otto Street

Port Townsend, WA 98368

Tel: $360-385-7707$

Toll Free: 800-962-2310

Fax: 360-385-6617

E-mail: sales@thermionics.com www.thermionics.com

Thermionics manufactures vacuum components, systems and accessories for production and research applications including: our new HCR Rotary e-Gun ${ }^{\mathrm{TM}}$ for demanding production coating applications; 3-20 $\mathrm{kW}$ e-Gun ${ }^{\mathrm{TM}}$ evaporation sources; Hanks $\mathrm{HM}^{2}$ e-Gun ${ }^{\mathrm{TM}}$ evaporation sources; PyraFlat ${ }^{T M}$ rectangular and other flanges and fittings; TriBond ${ }^{\mathrm{TM}}$ flanges; gate and poppet valves; DRS-1000 ${ }^{\mathrm{TM}}$ in situ, non-contact substrate temperature control system; sample handling and transfer systems; ion pumps; maTChed ${ }^{\mathrm{TM}}$ thermocouple gauges; mechanical, electrical and fluid feedthroughs; and materials and surface science systems.

\section{TherMold Partners, LP \#102}

652 Glenbrook Road

Stamford, CT 06906

Tel: 203-977-8161

Fax: 203-977-8237

E-mail: info@thermoldlp.com www.thermoldlp.com

TherMold manufactures and distributes its thermally stimulated current spectrometer (ISC) on a global basis. Current applications of the TSC are in the research and development of high performance materials, pharmaceuticals and plastics. It is a more sensitive alternative to DSC or DMA for detecting transitions that are dependent on changes in the mobility of molecular scale structural units. 
- ThermoMicroscopes \#312

1171 Borregas Avenue

Sunnyvale, CA 94089-1306

Tel: 408-747-1600

Fax: 408-747-1601

E-mail: info@thermomicro.com

www.thermomicro.com

ThermoMicroscopes is a result of the merger between Park Scientific Instruments and TopoMetrix. The new company is now the premier supplier of atomic force and scanning probe microscopes.

ThermoMicroscopes now offers instruments that operate in all environments (ambient, liquid and UHV) for research and industrial use. Stop by our booth for more information.

\section{Thomas Swan \& Co. Ltd. \#210}

Unit 1c, Button End

Harston

Cambridge CB2 5NX

UNITED KINGDOM

Tel: 44-1223-872282

Fax: 44-1223-871714

E-mail: sales@thomasswan.co.uk Thomas Swan is a leading manufacturer of MOCVD reactors, from single wafer customized R\&D to multiwafer production systems, based on the close-coupled showerhead (CCS) concept for the growth of InP, GaAs and $\mathrm{GaN}$ based materials. Peripheral products include Epison reagent concentration monitor and waste gas scrubbing systems.

TORR International, Inc. \#1210

12 Columbus Street

New Windsor, NY 12553

Tel: 914-565-4027

Toll Free: 888-622-TORR

Fax: 914-561-7731

E-mail: info@torr.com www.torr.com

TORR International offers the

following:

- Evaporation, E-beam, RF/DC sputtering systems, multigun, substrate heating, rotation, tilt; computer-controlled, standard/ custom-built. Sputtering guns, stand/UHV/magnetic (flex), targets, gas controllers.

- Reactive ion etchers

- RF/DV power supplies, special systems

- Servicing, refurbishing of all types of thin film and vacuum systems/vacuum pumps
TPL, Inc. \#710

Advanced Technologies

3921 Academy Parkway North NE

Albuquerque, NM 87109-4416

Tel: $505-342-4448$

Fax: 505-345-8155

E-mail: yspooner@tplinc.com

www.tplinc.com

TPL, Inc. produces electronic materials and nondestructive test instrumentation. The Porotec ${ }^{\mathrm{TM}}$ Thin Film Porosimeter is the only instrument capable of providing full BET and BJH analyses of thin films in their deposited forms. TPL produces $50 \mathrm{~nm}$, capacitor-grade barium and strontium titanate powders which can be customized for specific applications.

TSL

A Subsidiary of EDAX Inc. 392 E. 12300 South, Suite H Drapper, UT 84020

Tel: 801-495-2750

Fax: 801-495-2758

E-mail: sales@tsl-oim.com www.tsl-oim.com

(See EDAX Inc.)

\section{Universal Voltronics Corporation} \#722

27 Radio Circle Drive

Mt. Kisco, NY 10549

Tel: 914-241-1300

Fax: 914-241-3129

E-mail: sales@voltronics.com www.voltronics.com

Universal Voltronics Corporation makes high voltage DC output power supplies for various industrial uses including e-beam vapor deposition and $\mathrm{x}$-ray applications. UVC has over 40 years of high voltage experience in both linear and switchmode designs. UVC's product range encompasses: voltage levels from $1 \mathrm{kV}$ to $500 \mathrm{kV}$; power levels from 60 watts to $20 \mathrm{~kW}$ to 500 $\mathrm{kW}$; tight regulation and ripple tolerances; and air, oil, and potted insulation designs.

\section{Vacuum Atmospheres Company \#807 \\ 4652 W. Rosecrans Avenue \\ Hawthorne, CA 90250 \\ Tel: 310-644-0255 \\ Fax: 310-970-0980 Valves: for wafers to $300 \mathrm{~mm}$ and flat panel displays; port sizes to 6 inch $\times 24$ inch $(150 \times 600 \mathrm{~mm})$. \\ - Oil-sealed Rotary Vane Pumps: $1001 / \mathrm{min}$ to $8001 / \mathrm{min} ; 3.5 \mathrm{cfm}$ to $28 \mathrm{cfm}$.}

E-mail: sales@vac-atm.com

www.vac-atm.com/

Vacuum Atmospheres Company is a manufacturer of high quality, computer-controlled inert atmosphere glove boxes. Systems using our gas purification systems are capable of holding an atmosphere of less than $1 \mathrm{ppm}$ oxygen and moisture. We also have instrumentation that will measure oxygen and moisture not only in our systems but are adaptable for use in any inert atmosphere. Contact us at our corporate office at 310-644-0255 or in our east coast office at 978-762-0085.

\section{Vacuum Research Corporation \#516}

2419 Smallman Street

Pittsburgh, PA 15222

Toll Free: $800-426-9340$

Fax: 412-261-7220

E-mail: vrc(10 vacuumresearchcorp.com www.vacuumresearchcorp.com

- Dry Roughing Pumps: capacities from 6 to $32 \mathrm{cfm}$ (170 to 960

$1 / \mathrm{min})$; ultimate pressures to 15 mTorr (.02 mbar); cost from $\$ 6,400$ to $\$ 14,800$; "Soft Start" available on all models.

- Smart Dry Pump ${ }^{\mathrm{TM}}: 16$ cfm (450 $1 / \mathrm{min}$ ); $20 \mathrm{~m}$ Torr ultimate pressure; $\$ 7,150$.

- Wide Range Diaphragm Manometer: designed for CVD and other pump-out and backfill applications; 1 mTorr to 1500 Torr with a single transducer.

- Digital Pirani and Diaphragm Gauges: $10^{-5}$ to 1500 Torr linear analog output standard; high/low setpoints optional; $250^{\circ}$ Pirani sensors.

- Convection Gauges: $10^{-3}$ Torr to atmosphere; analog and RS485 outputs.

- Vacuum Switches: \pm 2 mTorr from 1 to 2000 mTorr; \pm 1 Torr from 2 to 1500 Torr.

- Stainless Steel and Aluminum Valves: ANSI, ISO and JIS flanges from 2 inch to 12 inch (63 to 320 $\mathrm{mm}$ ); bellows or o-rings stem seal; metal gasket or elastomer bonnet seal; motor operated throttle valves.

- Rectangular Port Aluminum

\section{Varian Vacuum Technologies} \#711, 713

121 Hartwell Avenue

Lexington, MA 02421

Tel: 508-528-1720

Fax: 508-528-1992

Varian Vacuum Technologies will exhibit a broad range of high vacuum equipment including the MacroTorr, maintenance-free ceramic-bearing turbo pump and the Starcell ${ }^{\circledast}$ ion pump. On display will be the Minuteman dry turbo station with the Eyesys self-contained gauge transducers, and the Model 979 leak detector.

\section{- VAT, Inc. \#701}

500 West Cummings Park

Woburn, MA 01801

Tel: 781-935-1446

Fax: 781-935-3940

E-mail: usa@vatvalve.com

www.vatvalve.com

VAT will display a variety of vitonsealed and all-metal sealed vacuum valves for pump isolation, loadlocks, downstream pressure control beam lines and other applications. Patented VATSEALS, a simple method for metal sealing flat surfaced flanges in any shape from $2 \mathrm{~K}$ to $300^{\circ} \mathrm{C}$, will also be shown.

\section{VG Scientific \#818}

100 Cummings Center

Suite 4071-G

Beverly, MA 01915

Tel: 978-524-1282

Fax: 978-524-1077

E-mail: gjones@vgscientific.com vgscientific.com

VG Microtech will be exhibiting a range of surface analysis components, including the new re-engineered LEED/Auger package featuring single unit electronics and the outstanding new SMARTOOL software. Also on display will be the highly successful new EX03 cross ionization ion gun. 
- Virginia Semiconductor, Inc. \#216

1501 Powhatan Street

Fredericksburg, VA 22401

Tel: 540-373-2900

Fax: 540-371-0371

E-mail: vasemi@juno.com

www.virginiasemi.com

Virginia Semiconductor, Inc. is a leading manufacturer of prime single crystal silicon substrates. Offering production quantities of 2 inch to 4 inch diameter silicon and small quantities of 1 inch to 6 inch diameter custom silicon substrates.

\section{R.D. Webb Company \#1209}

6 Huron Drive

Natick, MA 01760

Tel: 508-650-0110

Fax: 508-650-0555

E-mail: rdwebb@alum.mit.edu www.rdwebb.com

Manufacturer of the world's only air-cooled $2200^{\circ} \mathrm{C}$ vacuum furnacethe RED DEVIL ${ }^{\mathrm{TM}}$. Operating from a $20 \mathrm{amp} 120 \mathrm{~V}$ outlet (or $10 \mathrm{amp}$ $220 \mathrm{~V}$ ), the RED DEVIL ${ }^{\mathrm{TM}}$ requires only $2 \mathrm{KW}$ of power and no cooling water. The RED DEVIL ${ }^{\mathrm{TM}}$ comes complete with vacuum pump, pyrometer and programmable controller for only $\$ 31,400$.

\section{Well Diamond Wire Saws, Inc. \#420}

East Woods Business Center 4708 S. Old Peachtree Road Bldg. 500, Unit D

Norcross, GA 30071

Tel: 770-582-9887

Fax: $770-582-9339$

Well Diamond wire saws are designed and proven to cut smoothly, safely and with extraordinary precision through ceramics, glass, metal, rubber, plastics and all bonded materials regardless of the various hardnesses of the materials. Appropriate industrial applications include quality control, research and development, failure analysis as well as production environments. Manufactured in Europe for over twenty years with hundreds of systems in operation, Well Diamond Wire Saws, Inc. often provides "the only solution" to the most demanding cutting requirements.

\section{John Wiley \& Sons, Inc. \#925, 927 \\ 605 Third Avenue \\ New York, NY 10158 \\ Tel: $212-850-6000$ \\ Fax: 212-850-6088 \\ www.wiley.com}

Founded in 1807, John Wiley \& Sons, Inc. is an independent, global publisher of print and electronic products. Wiley specializes in scientific and technical books, journals, textbooks and education materials for colleges and universities, and professional and consumer books and subscription services. Wiley's Internet site can be accessed at http://www.wiley.com.

\section{- J.A. Woollam Co.. Inc. \#506} 645 M Street, Suite 102 Lincoln, NE 68508 Tel: 402-477-7501

Fax: 402-477-8214 E-mail: sales@jawoollam.com www.jawoollam.com Spectroscopic ellipsometers for nondestructive materials characterization: multi-layer thickness, optical constants, growth and etch rates, composition and more. Offering the widest spectral ranges availablevacuum ultraviolet to the far infrared (146 $\mathrm{nm}$ to 33 microns)to meet all your metrology needs.

\section{X-Ray Optical Systems, Inc. \#1005}

30 Corporate Circle

Albany, NY 12203

Tel: 518-464-3334

Fax: 518-464-3335

E-mail: info@xos.com

www.xos.com

We offer both standard and custom optics for use with $x$-rays and neutrons. Options for focusing, collimating, and beam bending are available. The useful range of energies for $x$-rays extends from $\sim 200 \mathrm{eV}$ to $30 \mathrm{keV}$. These optics are used to capture a large solid angle from the $x$-ray source and produce a quasiparallel beam of increased flux for use in XRD ( $\mathrm{x}$-ray diffraction) or small focused beams of high intensity for XRF ( $\mathrm{x}$-ray fluorescence) spectroscopy. Other applications are also being developed.
Zygo Corporation \#723

Laurel Brook Road

Middlefield, CT 06455

Tel: 860-347-8506

Fax: $860-346-4188$

E-mail: inquire@zygo.com www.zygo.com

Zygo Corporation designs and manufactures noncontact measuring instruments and automated systems, providing productivity and yield improvement solutions for manufacturers of precision compo- nents for the data storage, semiconductor, and other industries. Zygo provides a range of inspection, surface analysis, precision displacement measurement, and automated solutions. Our precision noncontact measuring instruments and systems enable manufacturers to increase operating efficiencies and product yields by identifying and collecting quantitative data on product defects during and after the manufacturing process.

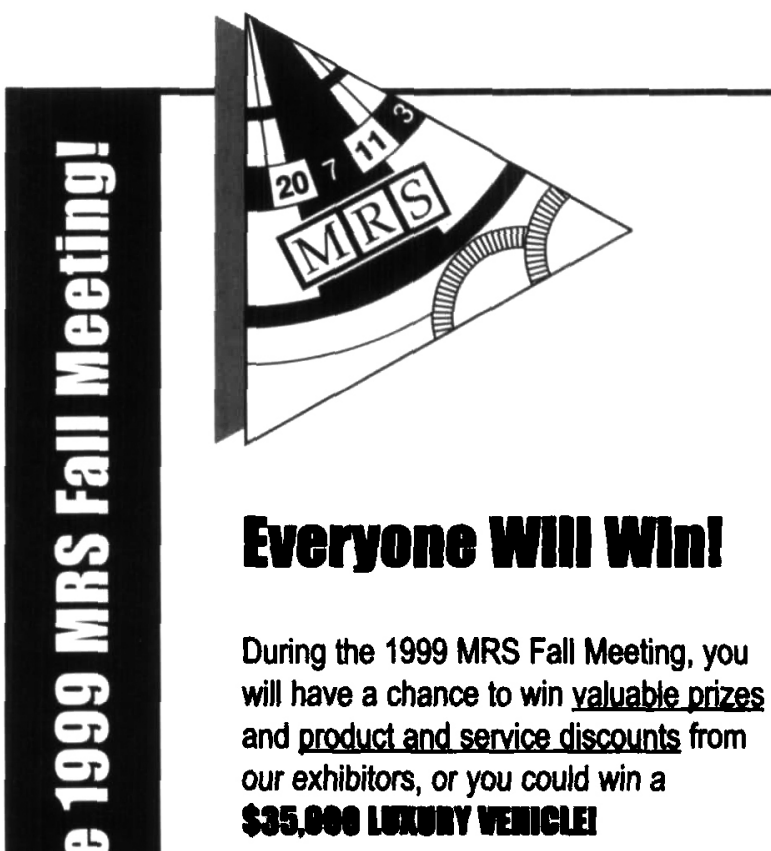

Here's what to do:

- Eot Yen firs Eomon good for one spin of the Grand Prize Wheel when you pick up your registration badge at the 1999 MRS Fall Meeting.

\section{- Sela tro tined in the Exhibit Hall Tuesday through Thursday during Exhibit hours.}

\section{- Belleet Your Fite in the Exhibit Hall}

All pre-registered and on-site registrants are eligible to participate. 


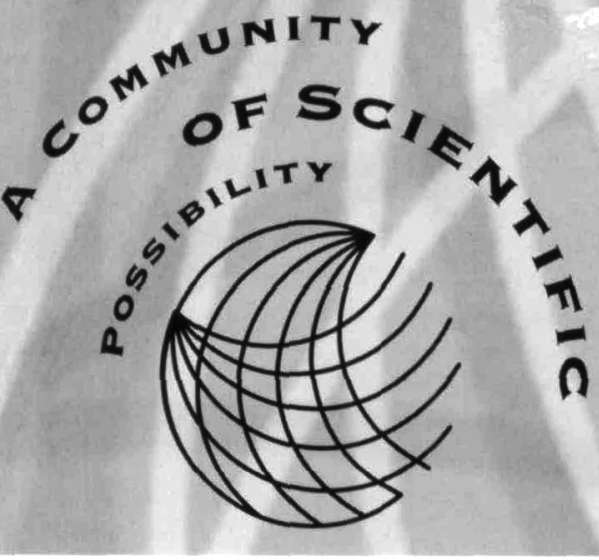

For me, the Materiols Reseorch Society is an important and exciting part of the scientific experience and I look forward to the Spring and Fall Meetings each year. These meetings, with their international coverage and wonderful interdisciplinary nature, have enabled me to meet scientists from around the world working in many fields, and hove broadened my understanding and enjoyment of materials science research. Frances M Ross BM Reseonch Division, Yorktown Hoights, NY

MRS keeps me up to date with the activities in the areas

of my current interests, and exposes me to exciting possibilities for future interests. Profeseor Midhod J. Axin Horvard University, Combridge, MA

Through various activities in MRS, I am consiantly reconnected with old friends. I am always delighted to hove an e-mail from out of the blue. And, I often turn to the MRS directory to contact on old colleague for a second opinion in an orea that is new to me.

We are all woven logether with our interest in materials, but each lends a distinct strand to the tabric of MRS. - Dr. Bethanie J. Stodler University of Minneseiv, Minnoopolis, MN

MRS is a great professional sociely for young materials scientists and engineers. I encourage my students to become MRS members and allend MRS meetings. $1 \mathrm{am}$ pleased to say that UCLA was the first university to establish an MRS Student Chapter-Professor King-Ning to University of Califomia-Los Angelos, CA

The meetings and publications which MRS hos developed provide excellent opportunities for both the multidisciplinory conlocts and the awareness of new science and thnologies which R\&D increasingly requires. - Dr. Pever Lednor Shal Research and Tachnology Contre, Amstandam

For the post 20 years, the Materials Research Sociely has provided me with outstanding forums for meeting and interocting with a broad spectrum of materials researchers on both rechnical and professional matters. The technical meetings hove allowed me to keep current in several areas of research, and the protessional relationships that I have established with other reseorchers through committee work have proven invaluable. Alon I. Toub Ford Motor Company, Dearbom, $M$
The primary goal of the Materials Research Society (MRS) is service...to its members and to the community of researchers in the science and engineering of modern materials. The Society's interdisciplinary approach differs from that of single-discipline professional societies because it promotes information exchange across the many technical fields touching materials development. Take control of your professional destiny-enroll today, and join the community of scientific possibility!

\section{* MRS MEETINGS \& WORKSHOPS}

Each year, more than 6000 members from around the world attend the MRS Spring and Fall Meetings and expand their professional network of contacts through the exchange of new ideas and information. MRS members enioy reduced registration fees for these meetings and for the new MRS Workshop Series.

\section{Journals \& Periodicals}

The Sociely offers two premier monthly publications. MRS Bulletin. soon in its 25 th year, is a monthly news magazine offering lechnical overview articles and focusing on news and trends in materials research education, policy and industry... and is free to MRS members. Journal of Materials Research (MMR) is the official journal of the Materials Research Society. Nearing its 15 th year, this archival publication is available to MRS members at a special discounted rate.

\section{NETWORKING OPPORTUNITIES \& CAREER SERYICES}

The annual Membership Directory is your connection to over 12,500 MRS members worldwide. In addition, the Sociely offers an Employment Center at both its Spring and Fall Meetings.

\section{UNIVERSITY CHAPTERS \& SECTIONS}

MRS Universily Chapters are created on universily campuses to foster discussion among students and facully across a broad range of malerials disciplines and to generate student interest in materials science. MRS Regional Sections provide local forums for the interaction of scientists and engineers in various materials disciplines of particular interest to that community. At present, MRS supports more than 40 active University Chapters and seven Sections.

\section{BOOKS \& VIDEOTAPES}

MRS publishes the proceedings of selected symposia as well as materials research related books. This series has become a standard reference in many areas of materials science and numbers over 600 volumes. MRS members may purchase these items at $15-30 \%$ off list price.

\section{AWARDS}

The MRS Awards Program acknowledges outstanding contributors to the progress of materials research, and recognizes their exciting and profound accomplishments. A variely of awards are offered to honor those whose work has already had a major impact in the field, as well as those whose work shows great promise for future leadership. 